\title{
A SECTION OF THE PALEOZOIC FORMATIONS OF THE GRAND CANYON AT THE BASS TRAIL.
}

\author{
By L. F. Noвle.
}

\section{INTRODUCTION.}

The thick series of horizontal strata of Paleozoic age which makes the greater part of the wall of the Grand Canyon is probably broadly familiar to more people than the strata exposed in any other area in the western United States. Each detail of form or color in the wall is so definitely associated with a bed or set of beds in the series that these strata are the very elements of the canyon landscape. Consequently they have been described not only by geologists but by many writers who have been interested in the Grand Canyon chiefly as a scenic spectacle.

In few areas, however, where the general character and succession of the rock formations is so familiar are the details of the stratigraphy so imperfectly known. In the Kaibab division of the Grand Canyon, which lies within the borders of the Grand Canyon National Park and is the best known and most visited part of the canyon, sections of the Paleozoic formations have been measured at four different places(1) at Nunkoweap Valley, by Walcott; ${ }^{1}$ (2) at Congress Canyon (now known as Red Canyon), along the Hance trail, by Frech; ${ }^{2}$ (3) at Bright Angel (Cameron) trail, by Darton ${ }^{3}$ and by me; ${ }^{4}$ and (4) in the region about Shinumo Creek and Bass Canyon, by me. ${ }^{5}$

None of these sections shows in detail the lithology of all the Paleozoic formations at any

\footnotetext{
1 Walcott, C. D., U. S. Geol. Survey Tenth Ann. Rept., pt. 1, p. 584, 1890.

${ }^{2}$ Frech, F., Section at Congress Canyon: Cong. géol. internat., 5e sess., Compte rendu, pp. 476-481, 1894.

${ }^{3}$ Darton, N. H., A reconnaissance of parts of northwestern New Mexico and northern Arizona: U. S. Geol. Survey Bull. 435, p. 21, 1910; Guidebook of the western United States, Part C, The Santa Fe Route: U. S. Geol. Survey Bull. 613, pp. 124-130, 1915.

${ }^{4}$ Noble, L. F., The geologic history of the Bright Angel quadrangle, Ariz.: U. S. Geol. Survey Bright Angel topographic map.

5 Noble, L. F., The Shinumo quadrangle, Grand Canyon district, Ariz. U. S. Geol. Survey Bull. 549, pp. 60-73, 1914.
}

one place, although some of them show the lithology of one or two formations in detail. Consequently none is adequate as a standard for close and accurate comparison and correlation of the formations from place to place in the canyon or for a detailed comparison with Paleozoic rocks exposed elsewhere in Arizona.

Realization of this lack of detailed stratigraphic information has led me to undertake a more thorough study of the Paleozoic rocks in the Grand Canyon than has been attempted previously. This work, begun in 1914 and continued in 1916 and 1920, has supplied material for a fuller description of the strata than was heretofore possible.

The present report includes a complete columnar section of the Paleozoic formations at the Bass trail, columnar sections of the Cambrian Tonto group at five other places in the Kaibab division, and a discussion of the age and correlation of the Paleozoic formations. Dr. Walcott has kindly furnished from his notes material for a fuller description of his section at Kanab Creek than has been published, and I have used this material freely in comparing and correlating the strata exposed at Bass Canyon, in the Kaibab division, with those exposed at Kanab Creek, in the Kanab division. I have also included in the report a section of the strata exposed in Cedar Mountain, a butte on the Coconino Plateau 2 miles east of the rim of the Grand Canyon near Tanner Canyon. This section carries the Grand Canyon geologic column up into the Mesozoic. The strata in Cedar Mountain, which is capped by the Shinarump conglomerate, of Triassic age, are the only remnants near the canyon rim of formations 
that once covered the region but have been removed by erosion.

A map of the Grand Canyon between Nunkoweap Valley and Kanab Creek (fig. 1) shows the localities cited in this report and indicates the position of most of the displacements that cut the Paleozoic strata in this region. A key map (fig. 2) shows the localities where I measured the section at the Bass trail.

The section at the Bass trail presented in this report (Pl. XIX) supplants the Paleozoic section given in my report on the Shinumo quadrangle, ${ }^{6}$ because, except for the Bright Angel shale, the section given in the Shinumo report is a generalized reconnaissance section and is inaccurate in detail, the thicknesses assigned to formations having been either estimated or obtained by means of rough aneroid measurement. Several of the formations described in the Shinumo report are herein redefined.

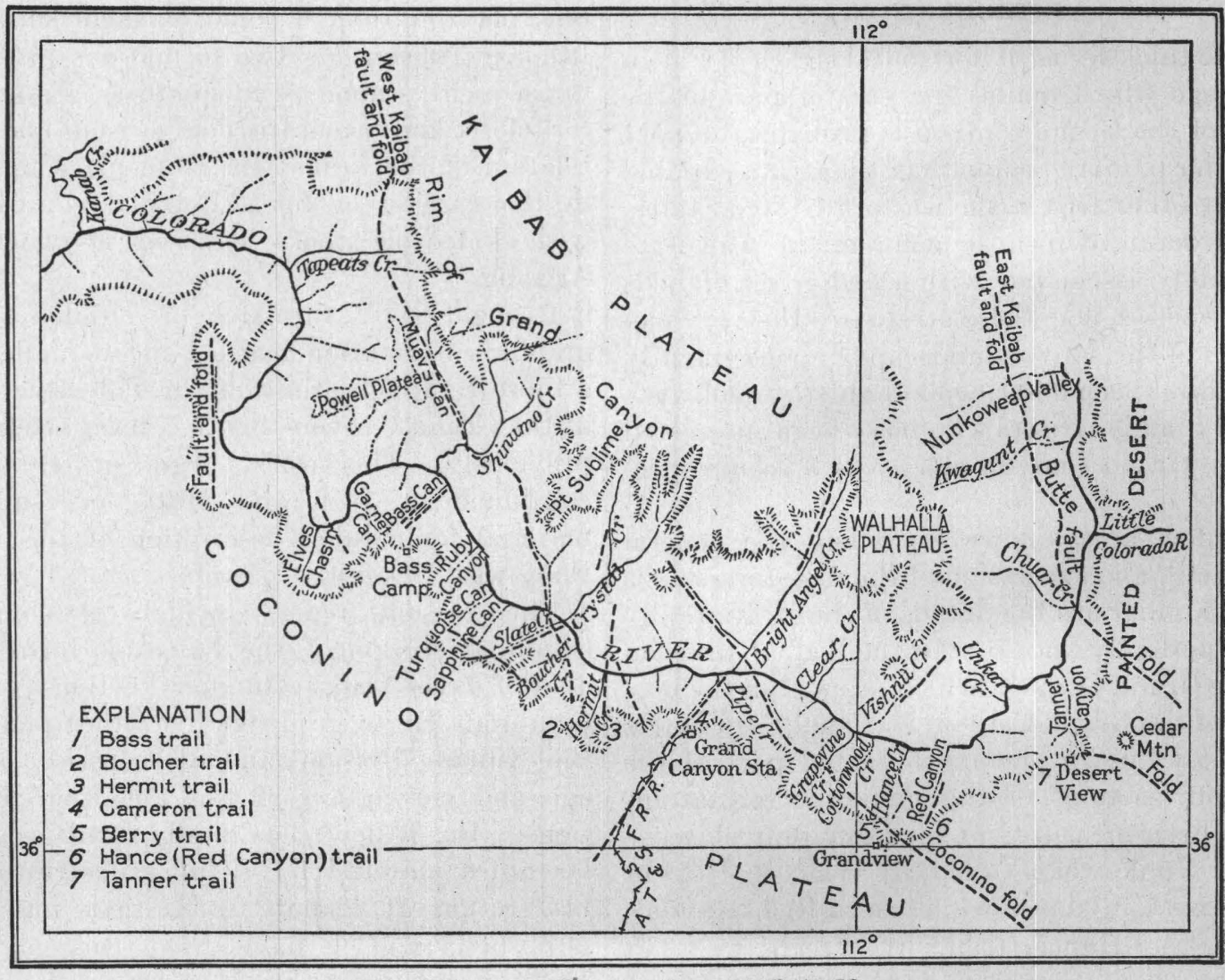

$5^{\prime \prime 2} 10 \quad 10$

FIGURE 1.-Map of Grand Canyon, Ariz., between Kanab Creek and Nunkoweap Valley. 


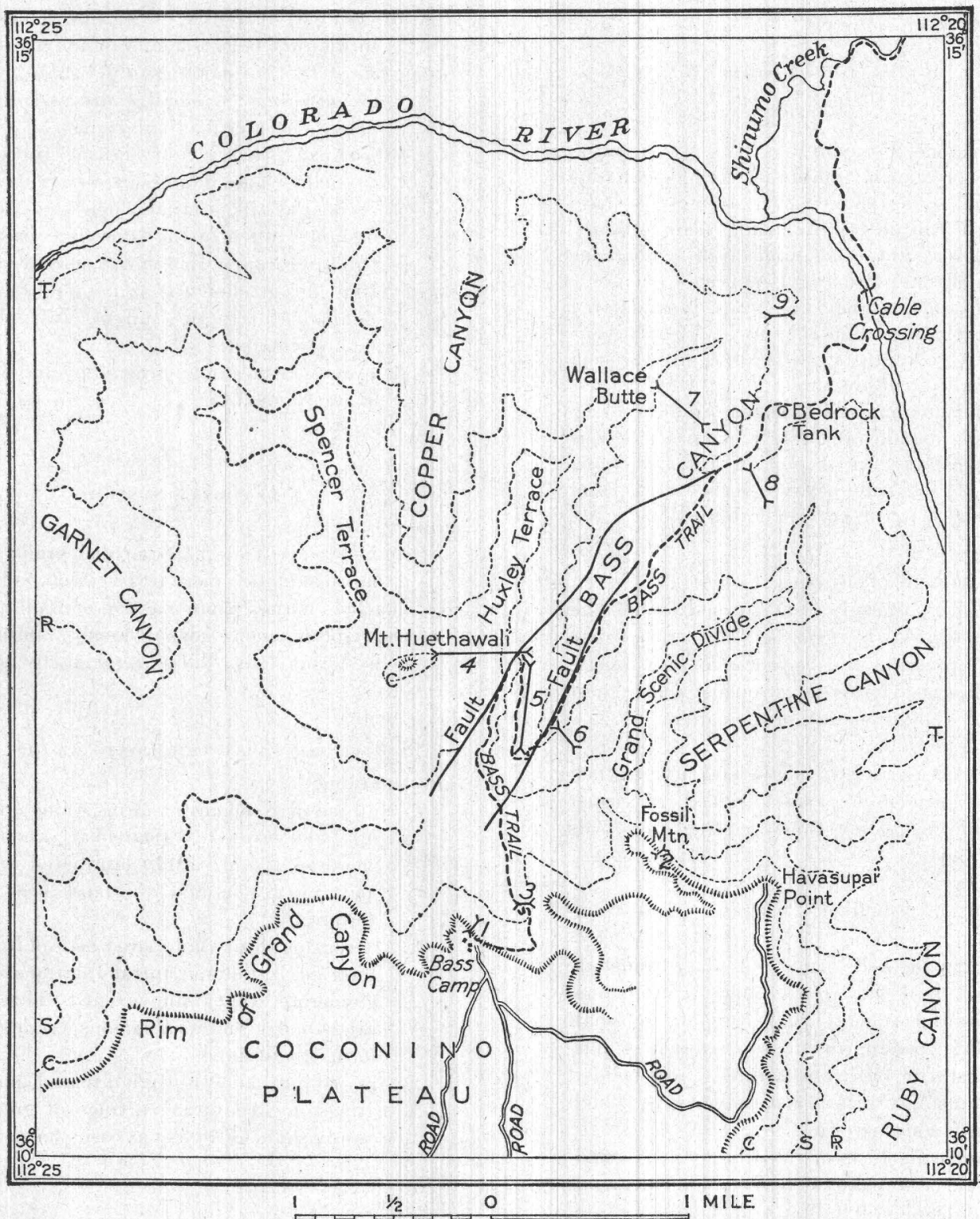

Figure 2.-Outline map of area about Bass trail, Shinumo quadrangle, Ariz,, showing localities where different parts of Paleozoic section were measured. Numbers correspond to those given in the detailed section. Dotted lines show cliffs as follows: T, Tapeats sandstone; R, Redwall limestone; S, Supai formation (uppermost cliff); C, Coconino sandstone. Hachures along rim of Grand Canyon and at Mount Huethawali show uppermost cliff formed by the Kaibab limestone. 
SECTION AT BASS TRAIL.

The section of Paleozoic rocks at the Bass trail is given below in two forms - a brief section showing the major subdivisions and a detailed section with comments on the beds.

Section of Paleozoic rocks at Bass trail.

\section{General section.}

CARBONIFEROUS SYSTEM.

Kaibab limestone (Permian):

A. Gray crystalline limestone, very fossiliferous and somewhat cherty, passing at base and top into alternating beds of very cherty limestone and buff calcareous sandstone; forms cliffs and steep slopes.

B. Buff and reddish fine-grained sandstone, poorly consolidated and irregularly bedded, containing beds of sandy breccia near top; forms slope..................

C. Buff sandstone and limestone in alternating beds, passing at top into massive siliceous limestone; upper portion forms a strong cliff; central portion forms cliffs and ledges; lower portion forms a slope......

Coconino sandstone (Permian):

Pale-buff, uniformly fine-grained sandstone characterized by crossbedding on a huge scale; presents the appearance of a single massive bed; forms the strongest and highest cliff in the upper wall of the canyon........

Hermit shale (Permian):

Deep brick-red sandy shale and fine-grained friable sandstone; characterized in upper portion by concretionary structure; beds form slope............................

Unconformity.

Supai formation (redefined; Permian (?) and Pennsylvanian):

A. Alternating beds of red soft platy sandstone and buff hard cross-bedded sandstone, forming a ledgy slope broken by small cliffs; passing down into reddish or purplish to buff fine-grained cross-bedded sandstone in heavy massive beds, which form a strong cliff.

B. Alternating beds of red friable shaly sandstone and massive cross-bedded calcareous sandstone including a few thin beds of limestone and a prominent bed of limestone conglomerate and forming a steep ledgy slope broken by small cliffs; passing down into reddish to buff fine-grained calcareous sandstone in heavy beds separated by thin layers of limestone or red shale and forming a strong cliff.......

C. Alternating beds of red shale, bluish-gray or purplish-gray limestone, and reddish to buff calcareous cross-bedded sandstone; passing down into alternating beds of red sandy shale and bluish or purplishgray limestone containing red chert; form ledgy slope broken by small cliffs; outcrops of many beds concealed by talus.

Unconformity (?)

Redwall limestone (redefined and restricted; Mississippian):

A. Bluish-gray massive crystalline limestone in distinct beds, some of which are separated by thin partings of red shale; forms a succession of small cliffs and ledges above sheer cliff of subdivision B......

B. Bluish-gray massive crystalline limestone in beds whose planes of separation are inconspicuous, so that when seen from a distance much of the limestone presents the appearance of a single massive stratum; forms sheerest and most sharply defined cliff in the canyon wall; thickness estimated..................... \pm 500

C. Brecciated limestone; forms slope under cliff

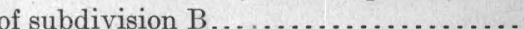

Unconformity (?).

Temple Butte limestone:

Thin-bedded buff and pale-purplish sandy magnesian limestone; more or less blotched and mottled; harder, more massive beds alternate with softer, more conspicuously laminated beds; forms ledgy slope broken by small cliffs..............................

Unconformity.

CAMBRIAN SYSTEM (TONTO GROUP).

Muav limestone:

A. Buff massive dolomite; forms strong cliff...

B. Buff fine-grained calcareous sandstone; massive at top, thinly laminated and in part micaceous and quartzose near base; forms cliff .......................

C. Alternating thinly laminated beds of impure mottled limestone, intraformational conglomerate, platy fine-grained micaceous sandstone, and calcareous sandstone; form steep slope....................

D. Gray to buff hard thinly laminated mottled limestone; contains partings of greenish sandy shale for 10 feet at base; forms cliff.

Bright Angel shale:

A. Thin-bedded greenish and buff micaceous shale and sandstone with interbedded layers of impure mottled limestone and glauconitic snuff-brown dolomite at the base; beds form steep slope or weak cliff. .

B. Thin-bedded greenish and buff micaceous shale and sandstone with two beds of snuff-brown dolomite and sandstone in the middle portion which form two conspicuous brown cllffs in a long slope made by the shales and sandstones............ 
U. S. GEOLOGICAL SURVEY

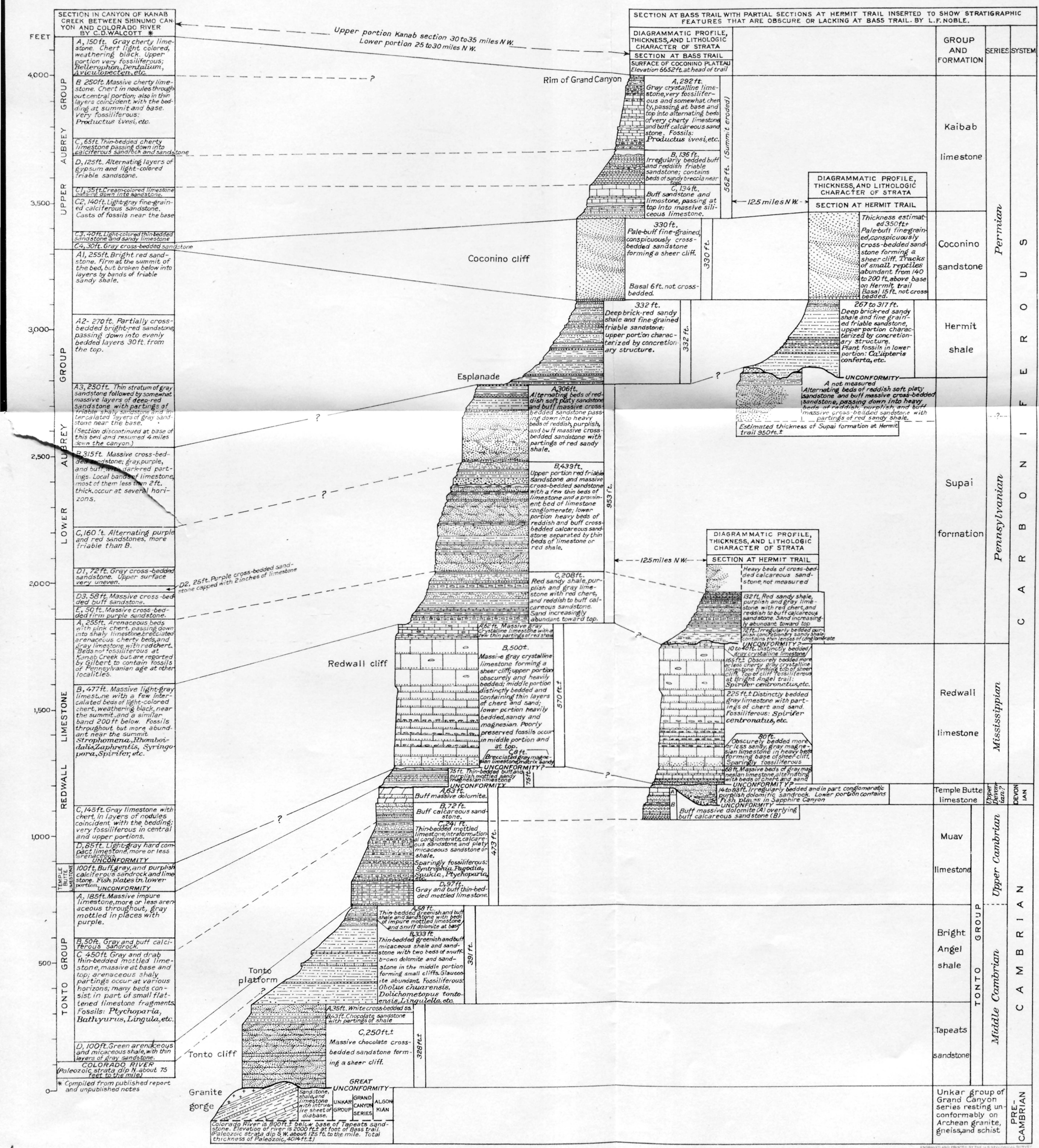

COLUMNAR SECTION OF THE PALEOZOIC STRATA OF THE GRAND CANYON AT BASS TRAIL 
Tapeats sandstone:

A. White cross-bedded sandstone; forms weak cliff.

B. Chocolate-colored sandstone with partings of shale; forms steep ledgy slope........

C. Massive chocolate-colored cross-bedded sandstone; forms sheer cliff along rim of Granite Gorge....................

Total thickness of Paleozoic rocks...... $\frac{\overline{\overline{ \pm 4,014}}}{\overline{328}}$

Kaibab limestone:

$$
\text { 2. Detailed section. }
$$

A. 1. Limestone, buff, compact; effervesces strongly with dilute hydrochloric acid; caps a small cliff on the rim of the canyon at the head of Bass trail. Bass Camp, on the Coconino Plateau, at the head of the trail, is built upon this stratum. Higher beds, which form the surface of the plateau just east of the camp, are not included in this section........................

2. Limestone (for analysis see p. 69), buff, siliceous; texture compact, chalky; contains small cavities lined with tiny crystals..........................

3. Sandstone, buff, fine grained, calcareous; effervesces with acid ............

4. Alternating thin beds of variegated chert and fine-grained calcareous sandstone.

5. Limestone, gray, crystalline, very cherty, fossiliferous. The chert occurs in nodules and in bands; in places it constitutes half of the rock. Aside from the abundance of chert the limestone resembles No. 6

6. Limestone (for analysis see p. 69), gray, hard, crystalline, somewhat cherty, very fossiliferous; effervesces strongly with acid. Beds differ greatly in thickness; some are a few inches thick, others several feet. The chert occurs in scattered nodules and in bands but is not a conspicuous feature of the rock............................

7. Alternating beds of fine-grained buff calcareous sandstone, buff limestone, and chert; form small conspicuous cliff.

8. Limestone, gray, hard, crystalline, somewhat cherty, fossiliferous; like No. 6 ..

9. Sandstone, lemon-buff, fine-grained, calcareous; bedding irregular, gnarly; forms a gentle slope covered in most places by talus.....................

10. Limestone, thin-bedded, very cherty; effervesces with acid. The chert constitutes over half of the rock and occurs in parallel bands whose average thickness is 2 inches.

[Note.-The foregoing section of subdivision $\mathrm{A}$ was measured under the rim of the canyon directly in front of Bass Camp, at locality 1, figure 2.]
B. 1. Sandstone, buff, massive, fine-grained, calcareous; effervesces weakly with acid............................

2. Breccia composed chiefly of angular fragments of evenly bedded buff finegrained sandstone embedded in a matrix of fine lemon-buff sand; contains a few fragments of siliceous limestone. The fragments range in diameter from less than an inch to over 4 feet. The contact of the breccia with the underlying sandstone is wavy and irregular, exhibiting in places inequalities of several feet...............

3. Sandstone, buff, fine-grained, friable. The component grains are quartz, as in other sandstones of the Kaibab, but are very loosely cemented, so that the rock crumbles to sand when struck with the hammer ...................

4. Sandstone like No. 3, but bright red....

5. Buff sandstone like No. 3 ..............

6. Bright-red sandstone like No. $4 \ldots \ldots$....

7. Lemon-buff sandstone like No. 3 ........

8. Bright-red sandstone like No. 4; contains a 1-inch layer of pale-green sandstone in the central portion...........

9. Sandstone, lemon-buff, fine-grained, friable; bedding irregular, gnarly; contact with underlying sandstone slightly wavy and irregular.

10. Sandstone, bright red, shaly; bedding gnarly; contact with underlying breccia wavy and irregular, exhibiting inequalities of 2 feet or more.............

1. Breccia composed of angular fragments of fine-grained sandstone averaging 4 inches in diameter. Very little matrix between the fragments. The appearance of the rock suggests that it was crushed and shattered after it was deposited. The contact with the underlying sandstone is irregular, exhibiting inequalities of several feet. .

12. Reddish-buff, loosely consolidated finegrained sandstone in indistinct but fairly even beds, some of which display gnarly structure; forms débris-covered slope; exposures poor. The upper 3 feet of the sandstone is bright red and thinly laminated................

13. Sandstone like No. 12 but more compact, forming a weak cliff; gnarled and twisted structure very pronounced; color lemon-buff to reddish buff.......

14. Sandstone like No. 12, very soft, forming a gentle slope that is covered nearly everywhere by talus; no good exposures obtainable. Colored white, lemon-buff, greenish, and bright red. In some places the color is in blotches or streaks; in others a single color characterizés each bed. .............. 
- [Note.-The foregoing section of subdivision $\mathrm{B}$ was measured on the northeast side of Fossil Mountain, at locality 2, figure 2.]

C. 1. Limestone, buff, dense, siliceous; in heavy, massive beds; forms a strong cliff; contains much chert in bands and nodules and many small cavities lined with crystals of quartz or calcite. In appearance the rock suggests silicified chalk. Some beds effervesce weakly with acid . ......................

2. Limestone like No. 1 but in thinner beds ( 1 foot or less) which are separated by thin partings of buff fine-grained shaly sandstone; forms a steep ledgy slope....

3. Limestone like No. 1 ; forms a cliff.......

4. Shaly sandstone, lemon-buff, soft, thinbedded, fine-grained; makes alcove under overhanging cliff of No. $3 . . . .$. .

5. Limestone, buff, in heavy beds with thin sandy partings, not notably siliceous; effervesces strongly with acid; forms cliff.

6. Shaly sandstone like No. 4 ; makes alcove under overhanging cliff of No. 5 ........

7. Limestone like No. 5 but in thinner beds (1 foot or less); forms slope.............

8. Limestone, buff, dense, siliceous, in heavy beds; contains numerous crystallined cavities apparently formed by the solution of brachiopods; does not effervesce with acid.................

9. Limestone like No. 7, in beds separated by very thin partings of sand

10. Sandstone, buff, fine-grained ..............

11. Limestone like No. 7 , but in a single bed.

12. Sandstone, buff, fine-grained............

13. Limestone, buff, siliceous, fossiliferous; does not effervesce with acid; contains numerous small cavities lined with calcite crystals.

14. Alternating beds of lemon-buff finegrained sandstone and buff limestone; beds average 3 inches in thickness....

15. Limestone, buff, not notably siliceous; effervesces strongly with acid.........

16. Sandstone, lemon-buff, fine-grained....

17. Sandstone, red, fine-grained. The base of this layer truncates inclined laminae of the underlying Coconino sandstone, which $\operatorname{dip} 15^{\circ} \mathrm{S} . . . \ldots \ldots \ldots \ldots . . . . .$.

[Note.-The foregoing section of subdivision $\mathrm{C}$ was measured directly above the point where the Bass trail descends the Coconino sandstone, at locality 3 , figure 2.]

Coconino sandstone: Pale-buff fine-grained sandstone, cross-bedded on a huge scale; appears like single massive bed; forms highest cliff in upper wall of canyon. The base of the sandstone is marked by an abrupt change from buff sandstone to underlying red shale, and the contact is an even line. In places the under surface of the sandstone shows impressions of sun cracks. For 25 feet above the base the cross-bedding is on a small scale, and horizontal layers alternate with cross-bedded layers; then the coarse cross-bedding begins and continues upward until the sandstone is truncated by the level base of the Kaibab. .....................

[NotE.-The foregoing section of the Coconino sandstone was measured on the Bass trail at the point where the trail descends the sandstone, at locality 3 , figure 2. At Mount Huethawali, a mile northwest of this point, the basal layer of the Coconino is massive sandstone 5 feet thick which displays no cross-bedding.]

1. Sandstone, red, soft, fine-grained, massive, with a thin layer of green shale at the top. Exhibits well-marked concretionary structure; the concretions are spheroidal forms which range from half an inch to 4 feet in diameter and consist of the general mass of the rock; in weathering, the rock splits off in concentric shells along the concretionary surfaces

2. Sandstone, fine-grained, massive; resembles the Coconino sandstone in texture and composition but is not crossbedded; lower half buff; upper half red with buff blotches................

3. Concretionary sandstone like No. 1 , in massive layers. ..................

4. Shale, deep red, thinly laminated, sandy.

5 . Beds of soft massive concretionary red sandstone like No. 1 alternating with thinner beds of deep-red shale like No. 4 ; sandstones and shales not conspicuously different in composition......

6. Shale, deep red, sandy ................

7. Sandstone, pink, hard, very fine grained; contains cracks and cavities filled with crystals of calcite (dog-tooth spar); rock itself does not effervesce with acid; forms small prominent cliff...........

8. Shale, soft, brick-red, thinly laminated, sandy.

9. Sandstone, brick-red, friable, massive; forms weak cliff

All underlying beds of shale are like No. 8; all underlying beds of sandstone like No. 9 . The beds designated shale and sandstone actually differ little in composition; both consist essentially of sandy mud colored red by a strong ferritic pigment. The beds designated sandstone are massive and relatively compact, as contrasted with the beds designated shale, which are thinly laminated and soft. Both types of rock are friable. 
10. Shale, containing beds of massive friable sandstone near the top..............

11. Sandstone in massive beds; contains a 1-foot layer of shale in the middle portion; forms weak cliffs...............

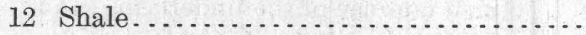

13. Sandstone; forms weak cliff . ..........

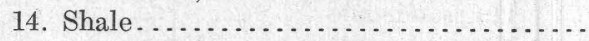

15. Alternating lenticular beds of intraformational conglomerate and red finegrained sandstone averaging 1 foot in thickness; beds display indistinct sun cracks and rain prints; form weak cliff. The conglomerate consists chiefly of flattened pebbles of fine-grained sandstone or sandy shale less than 1 inch in diameter embedded in a matrix of red sandy mud but contains some nodular or concretionary fragments of limestone

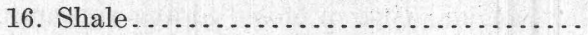

17. Sandstone $. . . \ldots \ldots \ldots . . . . . . . . . .$.

18. Shale....................

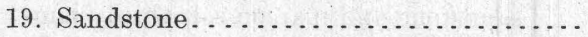

20. Shale..........................

21. Sandstone; forms weak cliff. ..........

22. Shale ..........................

23. Sandstone; forms weak cliff ...........

24. Shale.........................

[NotE.-The foregoing section was measured at the east end of Mount Huethawali, about a quarter of a mile northwest of the point where the Bass trail begins to descend into Bass Canyon, at locality 4 , figure 2.]

Supai formation:

A. 1. Sandstone, white, fine-grained, crossbedded, hard, calcareous; effervesces with acid; contains many cracks lined with calcite; forms a small conspicuous cliff and determines a wide shelf at the general level of the Esplanade platform. At the point where the section was measured the floor of the Esplanade consists in part of this sandstone and in part of knolls of soft red Hermit shale which overlie the sandstone........................

2. Sandstone, red, soft, friable, platy, finegrained; forms a long, gentle slope....

3. Sandstone, buff, fine-grained, massive, weathers white; effervesces with acid; unites with underlying bed in forming a cliff

4. Sandstone, pinkish buff, cross-bedded...

5. Red soft platy sandstone like No. 2; forms slope.

6. Massive buff sandstone like No. 3 ; hard; forms strong cliff .................

7. Red soft platy sandstone; forms slope...

8. Pinkish-buff cross-bedded sandstone like No. 4; forms cliff.

$91048^{\circ}-23-3$
A. 9. Soft platy beds of red sandstone alternating with harder, more massive beds; form long ledgy slope................

10. Pinkish-buff cross-bedded sandstone; upper surface weathers white; forms cliff.

11. Red soft platy sandstone; forms wastecovered slope. ..................

12. Pinkish-buff cross-bedded sandstone; forms cliff .....................

13. Red soft platy sandstone; forms wastecovered slope...................

14. Fine-grained sandstone in heavy, massive beds, some of which are separated by thin partings of red soft platy sandstone; cross-bedded throughout; inclined laminae dip south; some beds near the base display an irregular, gnarly structure. The prevailing color of the upper 40 feet of the sandstone is pale brick-red; that of the lower 125 feet ranges from pale purplish to buff. The rock of most beds does not effervesce with acid. A bed of sandy limestone or very calcareous sandstone 2 feet thick occurs 35 feet above the base of the sandstone.

A. 15. Conglomerate, composed of subangular fragments of sandstone embedded in a matrix of fine sand of the same composition as the fragments; probably an intraformational conglomerate; displays a rude concretionary structure; fragments weather by splitting off in concentric shells. Many of these shells are embedded in the matrix. The conglomerate varies in thickness and in places is absent; appears to rest upon a slightly uneven surface.............

[Note.-At the rim of Bass Canyon directly east of Mount Huethawali subdivision $A$ of the Supai is cut by a fault which breaks the strong cliff formed by bed 14. The Bass trail descends the cliff in a shattered zone a ? ong the fault. The strata have been displaced about 130 feet by the fault, those on the east side being relatively lowered. In measuring subdivision $\mathrm{A}$ at Bass trail it was necessary to divide the section at the fault. Beds 1 to 13 and the upper 40 feet of bed 14 were measured west of the fault, in the slope between the trail and the base of Mount Huethawali, at locality 4, figure 2. Bed 15 and the lower 125 feet of bed 14 were measured on the trail just east of the fault, at locality 5 , figure 2 . The thickness which I have assigned to bed 14 may be incorrect, because I could not locate equivalent layers in 
the bed on opposite sides of the fault, owing to the homogeneity of the sandstone.]

B. 1. Magenta or reddish platy fine-grained shaly calcareous sandstone; effervesces with acid; forms slope.............

2. Hard massive sandy limestone or very calcareous sandstone; effervesces strongly with acid; unites with underlying bed in forming cliff.............

3. Gnarly sandstone blotched purplish and buff. ...........................

4. Red friable sandstone; forms slope......

5. Buff cross-bedded calcareous sandstone; forms cliff.

6. Red friable shaly sandstone; forms slope.

7. Alternating lenticular beds of conglomerate and fine-grained sandstone, both cross-bedded. Most of the conglomerate consists of well-rounded waterworn pebbles 4 inches or less in diameter embedded in a matrix of red mud and sand; most of the pebbles are bluish-gray or purplish-gray nodular limestone, but some are fine-grained sandstone. Some beds exhibit the peculiar concretionary structure that characterizes bed 15 of subdivision A and consist of subangular fragments of sandstone ranging from less than 1 inch to more than 2 feet in diameter embedded in sand of the same composition as the fragments. The beds of conglomerate and sandstone rest on an uneven surface that exhibits a relief of several feet.

8. Red friable shaly sandstone; forms slope.

9. Pinkish-buff cross-bedded calcareous sandstone; unites with underlying bed in forming cliff....................

10. Pink hard massive sandy limestone or very calcareous sandstone; effervesces strongly with acid...................

11. Red friable soft sandstone; exhibits concretionary structure; forms slope......

12. Buff cross-bedded sandstone; forms cliff.

13. Beds of red shale and soft concretionary calcareous sandstone; form alcove under cliff of No. 12..............

14. Light brick-red to pinkish-buff, rather soft cross-bedded calcareous sandstone with a few interbedded layers of red shaly sandstone; forms a steep ledgy slope broken by weak cliffs; some beds contain elongated rudely cylindrical or conical forms which are lighter in color than the mass of the rock and in places weather out of the rock. These forms are of various sizes, but most of them are less than 1 inch in diameter. They are undoubtedly organic in origin and may be fucoids.............
B. 15. Red friable soft thinly laminated sandstone; forms slope.

16. Massive sandy limestone or very calcareous sandstone; rests on a slightly uneven wavy surface that truncates inclined laminae of the underlying sandstone; caps cliff formed by the underlying sandstone

20. Nodular purplish-gray limestone; contains large numbers of the obscure forms noted in bed 19; caps cliff formed by underlying bed. ..........

21. Buff cross-bedded calcareous sandstone; like No. 17 , but the cross-bedding is on a less coarse scale; forms strong cliff...

22. Beds of calcareous sandstone blotched red and buff separated by thin beds of maroon shale which exhibit suncracked surfaces; form alcove under cliff of No. 21. The Bass trail follows this alcove southward to a gulch in which it descends a long rock slide to the base of the Supai...............

23. Hard pinkish or purplish fine-grained limestone blotched greenish buff; crystalline in places; contains the obscure forms noted in bed 19 , also small masses, largely calcite, whose outlines suggest those of brachiopods; with underlying beds forms strong cliff...

24. Beds of pinkish fine-grained limestone; form cliff

25. Buff cross-bedded calcareous sandstone like No. 21; forms cliff...............

26. Red shale; forms small alcove...........

27. Buff cross-bedded calcareous sandstone like No. 21 , divided into two beds by a thin parting of red shale in the center; forms strong cliff. The under 
surface of the lower sandstone bed exhibits casts of sun cracks at the contact with the underlying shale............

B. 28. Maroon shale ..........................

29. Massive buff calcareous sandstone; base slightly uneven, wavy.............

C. 1. Bluish-gray nodular limestone mixed with red mud which imparts a blotched or mottled appearance to the rock....

2. Maroon shale; exhibits concretionary structure; in part brecciated; crac'zs between fragments infiltrated with red mud; contact with underlying bed uneven, wavy ...................

3. Bluish-gray nodular limestone mixed with purplish mud, some of which appears to have been infiltrated along cracks; in part brecciated; contains the obscure forms, probably fucoids, noted in $\mathrm{B} 14,20$, and other beds..........

[Note.-Beds B 28 and 29 and C 1, 2, and 3 form an alcove under the cliff at the base of subdivision B. The foregoing section, including all of subdivision $\mathrm{B}$ and beds 1 to 3 of subdivision C, was measured on or near the Bass trail on the west side of Bass Canyon, at locality 5, figure 2.]

4. Slope covered by talus, largely concealing underlying rock. Exposed beds consist of purplish platy calcareous sandstone or sandy limestone, blotched buff, separated by thin layers of red shale..........................

5. Pinkish-buff hard cross-bedded calcareous sandstone; forms cliff..............

6. Red platy sandy shale.................

7. Bluish-gray compact crystalline cherty limestone passing downward into hard cross-bedded calcareous sandstone; forms cliff.

8. Cross-bedded calcareous sandstone with a 2-inch layer of red shale at the base; forms steep slope.....................

9. Purplish sandy limestone; unites with underlying bed in forming a cliff; contact with underlying bed uneven, exhibiting inequalities of 2 feet in places.

10. Hard cross-bedded calcareous sandstone.

11. Red soft shaly sandstone; in part crossbedded; forms a weak cliff..........

12. Red sandy shale; forms slope.........

13. Bluish-gray limestone with conspicuous bands of reddish or pink chert; in places the limestone is mixed with reddish or purplish mud, which imparts a mottled appearance to the rock......

14. Red sandy shale; forms slope..........

15. Purplish sandy limestone, in part crystalline; contains a few nodules of red chert; forms slope. . . . . . . . . . . . . .

16. Red soft fine-grained shaly sandstone in platy beds; forms slope. . . . . . . . . .
C. 17. Buff hard fine-grained calcareous sandstone; forms strong cliff. ...........

18. Buff fine-grained shaly sandstone; in part conglomerate composed of lumps of chert and buff sandy limestone averaging an inch in diameter; forms slope........................

19. Red shale; forms slope...............

20. Bluish-gray limestone containing parallel bands of red chert.................

21. Purplish massive friable sandy shale speckled with small circular buff spots, passing down into bluish-gray nodular cherty limestone.................

22. Gnarly nodular bed composed of lumps of purplish sandy shale mixed with purplish mud....................

23. Conspicuously banded bed composed of bluish-gray limestone and white or red chert; forms strong cliff; the alternating bands of chert and limestone average an inch in thickness; in places the limestone at the summit of the bed is mixed or infiltrated with red mud...

24. Gentle slope covered by talus which conceals the bed so completely that no outcrops can be found. The bed appears to be a reddish or purplish soft shale.......................

[Note.-The foregoing section was measured on the east side of Bass Canyon a quarter of a mile northeast of the point where the Bass trail descends a break in the Redwall cliff at the head of the canyon, at locality 6 , figure 2 . This break is on the line of a fault along the axis of Bass Canyon. The strata are displaced about 75 feet by the fault, those on the west side of the canyon being relatively lowered.]

Redwall limestone:

A. 1. Bluish-gray massive limestone in heavy beds; contains a few scattered nodules of chert; forms strong cliff............

2. Red, purple, or greenish-buff shale; thinly laminated; forms slope.........

3. Beds of bluish-gray limestone separated in places by paper-thin partings of red shale; form steep ledgy slope.........

4. Bluish-gray limestone and red shale in alternating beds which average 1 inch thick; form slope.................

5. Crystalline limestone; white on freshly broken surfaces; effervesces strongly with acid; contains a few chert nodules and here and there a poorly preserved fossil (see pp. 56-57); forms strong cliff.

6. Bluish-gray crystalline limestone in beds less than 6 inches thick separated by paper-thin partings of reddish or buff
9

12

2

5

1 
sandy shale; wastes back in a slope, leaving a ledge at the summit of the sheer cliff of subdivision B..........

[Nоте.-The foregoing section was measured on the east side of Bass Canyon directly under the place where subdivision $\mathrm{C}$ of the Supai was measured, at locality 6 , figure 2.]

B. Massive crystalline limestone forming a sheer high cliff; upper portion heavily and obscurely bedded; middle portion distinctly bedded and containing many thin interbedded layers of chert and sand; lower portion heavily bedded and magnesian. Most beds contain scattered nodules of chert. Many contain coarse crystals of calcite; some of the calcite lines cavities; some of it occurs in large masses in the rock; some of it forms beds several inches to a foot thick. Intercalated layers of sand are commonly less than a foot thick, are loosely cemented, and exhibit gnarly structure; most of them rest on irregular, wavy surfaces. In many places the limestone cliff is stained pink by ferritic pigment washed over it from overlying red shales; unstained surfaces of the limestone weather bluish gray; freshly broken surfaces are gray, buff, or white. Subdivision B is rudely divisible into three members, as follows:

1. Obscurely bedded limestone, most of which is in heavy beds; beds differ greatly in thickness, some being over 20 feet thick, others only a few inches; most of the limestone is finely crystalline, light gray or white on freshly broken surfaces, and very pure (for analysis see p. 55); effervesces strongly with acid. Contains a few thin beds of sand, some chert, and much calcite in coarse crystals. Surface of limestone at top of cliff exhibits very poorly preserved fossils. Thickness estimated.. \pm 200

2. Distinctly bedded limestone in rather uniform beds, most of which do not exceed 5 feet in thickness; limestone beds alternate with thin layers of chert or sand; effervesce strongly with acid; some beds are very fossiliferous, but fossils are poorly preserved. Owing to its laminated character this member is less resistant to erosion and recedes faster than the overlying heavy-bedded limestone, so that in many places it is overhung by the overlying member. This difference in erosion determines the formation of great niches or alcoves in the Redwall cliff. Thickness estimated....................... \pm 220

B. 3. Heavy-bedded magnesian limestone; chemical composition near that of dolomite (see analysis, p. 55); does not effervesce freely with acid; some beds are separated by thin layers of loosely consolidated sandstone; under Wallace Butte the limestone rests on a layer of loose gnarly sandstone 1 foot thick. Thickness estimated........ \pm 80

[NoтE.-The foregoing section of subdivision $\mathrm{B}$ was examined along the Bass trail, at locality 6 , figure 2 . The thickness assigned to subdivision $\mathrm{B}$ is the thickness of its cliff under Wallace Butte in Bass Canyon as measured on the topographic map of the Shinumo quadrangle.]

C. Brecciated limestone composed of subangular fragments of limestone 6 inches or less in diameter embedded in a matrix of yellowish or purplish sand; in places passes into gnarly calcareous sandstone or into limestone containing irregular masses of yellowish or purplish sand; forms steep slope or weak cliff under sheer cliff of subdivision B. In places the base of this curious bed is uneven; in places the summit is uneven. Average thickness............

[NотE.-The foregoing section of subdivision $\mathrm{C}$ was measured under Wallace Butte on the west side of Bass Canyon, at locality 7 , figure 2.]

Temple Butte limestone:

1. Thinly laminated sandy magnesian limestone in rubbly beds mottled pale purplish or buff; effervesces feebly with acid; soft; forms slope. Some mottled beds resemble beds in the Muav limestone that have been bored by worms........................

2. Limestone like No. 1 but harder and more massive; forms small cliff

3. Thin beds of limestone like No. 1 alternating with thin beds of intraformational conglomerate composed largely of flattened pebbles of limestone; form slope..........................

4. Limestone like No. 2 ; forms cliff.........

5. Limestone like No. 1 ; forms slope.........

6. Limestone like No. 2 ; forms small cliff...

7. Limestone like No. 1; forms slope.........

8. Limestone like No. 2; forms strong cliff..

9. Limestone like No. 2; forms cliff. 
10. Massive bed of purplish crystalline magnesian limestone; forms cliff..........

11. Limestone like No. 2; forms cliff; surface exhibits cross sections of poorly preserved cup corals (?)...............

12. Limestone like No. 1 ; forms slope........

13. Limestone like No. 2 ; forms cliff.........

14. Limestone like No. 1 (for analysis see p. 52); very soft; forms gentle slope above strong cliff at top of underlying Muav limestone....................

[NoтE.-The foregoing section was measured under Wallace Butte on the west side of Bass Canyon, at locality 7 , figure 2. At this locality the contact between bed 14 and the underlying Muav limestone exhibits no irregularity in a distance of 1,000 feet, and the bed appears to rest conformably upon the Muav limestone, but in Ruby Canyon, 2 miles southeast of Bass Canyon, the contact is very uneven, exhibits vertical inequalities of 40 feet or more in horizontal distances of a few hundred feet, and clearly represents a strong line of erosion.]

Muav limestone:

A. 1. Buff hard massive crystalline dolomite in heavy beds (for analysis see p. - ) ; does not effervesce with acid; forms cliff. At one place on the east side of Bass Canyon the thickness of the dolomite is 25 feet less than it is under Wallace Butte, on the west side of the canyon, where this section was measured. Apparently a depression in the surface of erosion at the top of the Muav exists at that point, but the feature is obscure because fans of talus mask the strata for some distance on both sides of the exposure.......................

2. Poorly exposed bed of soft rock, apparently greenish-buff shaly sandstone; determines a narrow ledge which breaks the cliff formed by Nos. 1 and 3

3. Buff hard massive crystalline dolomite in heavy beds; probably originally a very fine calcareous sand; exhibits indistinct cross-bedding; forms cliff.

B. Pale-buff to greenish-buff fine-grained calcareous sandstone blotched purplish in places; beds differ greatly in thickness, ranging from a fraction of an inch to 6 feet; some beds are massive; others thinly laminated; some exhibit indistinct cross-bedding; massive beds predominate in upper part of the sub- division, thinly laminated beds in lower part. The sand is prevailingly calcareous; many beds effervesce readily with acid, and specimens of these beds tested in the Survey laboratory show little magnesium; the rock in a few massive beds, however, resembles the overlying dolomite (A 3), effervesces feebly, and is magnesian. Some of the sand is finely micaceous, and some is finely quartzose. A number of the beds contain tiny greenish grains of glauconite. Some beds are worm-bored. Beds of intraformational conglomerate composed of flattened pebbles of calcareous sandstone occur at several horizons. A thin layer of reddish sandy shale associated with a bed of intraformational conglomerate, 40 feet above the base of the subdivision, exhibits well-preserved sun cracks. The laminated beds at the base of the subdivision consist chiefly of platy micaceous sandstone which does not effervesce with acid . ........

C. 1. Thin layers of calcareous intraformational conglomerate, platy greenish micaceous sandstone, greenish micaceous shale, and buff cross-bedded calcareous sandstone in countless alternations. The intraformational conglomerate consists essentially of small flattened pebbles of gray and buff mottled limestone like that of subdivision D and buff calcareous sandstone; all parts of it effervesce with acid. The pebbles have rounded edges and are cemented together by fine-grained calcareous micaceous sandy mud or by calcium carbonate. Most of the rock contains worm burrows and fucoidal casts filled with buff sand. Beds range in thickness from less than half an inch to 6 inches and are lenticular; many wedge out in distances of 100 feet; some pass horizontally into cross-bedded sandstone; small local unconformities are common. Some beds are blotched purplish. Many layers of the micaceous sandstone and shale are as thin as cardboard. Much of the calcareous sandstone consists almost entirely of calcium carbonate and might be classed as limestone, but the cross-bedding reveals its clastic origin. In most places bed 1 and the underlying beds 2 to 7 form cliffs .....

2. Gray and buff mottled limestone like subdivision $\mathrm{D}$, but in beds separated by partings of buff sand as thin as cardboard........................

3. Intraformational conglomerate like that in

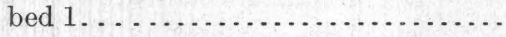


C. 4. Mottled limestone in thin beds with sandy partings. .....................

5. Intraformational conglomerate ........

6. Mottled limestone in thin beds with sandy partings. . . . . . . . . . . . . . . .

7. Intraformational conglomerate........

8. Beds of intraformational conglomerate averaging 6 inches thick alternating with thin beds of gray and buff mottled limestone; form steep cliff. ...........

9. Hard massive bed of intraformational conglomerate; forms small cliff. .........

10. Beds like No. 8 but containing numerous very thin partings of fine micaceous and calcareous buff sandstone near base; form slope.................

11. Buff fine-grained crystalline limestone, weathering snuff-brown; effervesces strongly with acid; exhibits indistinct cross-bedding and is probably composed of fine calcareous sand; hard; forms small conspicuous brown cliff and is a very persistent bed in the western part of the Kaibab division, being traceable throughout the Shinumo quadrangle......................

12. Beds of gray and buff mottled limestone and intraformational conglomerate in countless alternations; contain many thin partings of fine-grained buff or greenish-buff micaceous and calcareous sand; worm borings and fucoidal casts abundant; beds form slope. In general the beds of mottled limestone contain more buff fine sandy material than those which constitute the underlying subdivision $\mathrm{D}$, although some are comparatively pure. An analysis of a sample from a typical bed of the impure mottled limestone 35 feet below the top of No. 12 in Turquoise Canyon (seep. 43) shows that about a quarter of the rock consists of insoluble material, probably silica, whereas the remainder consists essentially of calcium carbonate with only a trace of magnesium. The beds of intraformational conglomerate effervesce as freely with acid as the mottled limestone; tests indicate that they are not magnesian and that they probably differ little in chemical composition from the impure mottled limestone.... 14

D. Gray and buff hard thin-bedded mottled limestone; effervesces with acid; forms strong cliff. The color of the pure limestone is gray to bluish gray, but many beds contain a varying amount of buff fine calcareous, more or less micaceous sand or sandy mud which imparts a mottled appearance to the rock. The limestone contains numerous fucoidal or coralloid forms, most of which are composed of the buff sandy material, but some of which are com- posed of the limestone itself. Probably most of these forms are filled worm burrows. At the base of the subdivision thin layers of platy buff sandstone and greenish shale alternate with the mottled limestone for about 10 feet...

[Note.-The foregoing section of the Muav limestone was measured under Wallace Butte on the west side of Bass Canyon, at locality 7, figure 2.]

Bright Angel shale:

A. Beds of greenish soft micaceous shale in paper-thin laminae alternating with beds of buff platy hard fine-grained micaceous quartzose sandstone which range in thickness from a quarter of an inch to an inch; worm borings abundant; beds form alcove under cliff of subdivision D of Muav limestone.....

2. Alternating thin beds of worm-worked buff calcareous sandstone and greenishbuff micaceous sandy shale; form steep slope..........................

3. Thin beds of buff sandstone, greenish shale, mottled limestone like subdivision D of the Muav, and snuff-brown dolomite in countless alternations; most beds less than 1 inch thick; worm borings abundant; many layers of sandstone ripple-marked; beds form weak cliff ............................

4. Snuff-brown hard crystalline glauconitic dolomite forming small cliff. The glauconite appears to constitute from a quarter to a half of the rock and occurs in tiny rounded grains scattered through a groundmass of crystalline dolomite. Although the rock is crystalline, weathered surfaces exhibit distinct cross-bedding, showing that the rock is of classic origin......

B. Thin beds of buff platy quartzitic sandstone and greenish micaceous shale in countless alternations; glauconite very abundant at top; a 4 -inch bed of magenta sandstone containing groundup remains of linguloid brachiopods and much glauconite occurs 7 feet above the base; neither sandstone nor shale effervesces with acid; beds form slope. The sandstone beds average a quarter of an inch in thickness and consist chiefly of tiny transparent grains of quartz but contain small flakes of muscovite and scattered grains of glauconite; most beds speckled with small reddish or brownish spots; ripple marks and worm burrows abundant. Much of the shale is in paper-thin laminae whose surfaces exhibit a satiny luster imparted by innumerable tiny flakes of muscovite; many outcrops are 
covered with a whitish saline efflorescence.........................

B. 2. Magenta to dark-green glauconitic sandrock passing at top into a 6 -inch bed of snuff-brown glauconitic crystalline dolomite; forms weak cliff. In places the sandrock and dolomite pass into intraformational conglomerate containing broken shells of linguloid brachiopods. The dark-green phase of the sandrock owes its color to glauconite; the magenta phase owes its color to ferritic cement, largely hematite, which makes the rock relatively heavy

3. Buff platy sandstone and greenish shale like No. 1 ; beds form slope.............

4. Dark magenta cross-bedded sandstone containing much glauconite; forms small cliff......................

5. Buff platy sandstone and greenish shale like No. 1; glauconite very abundant; beds form slope...................

6. Thin beds of snuff-brown to buff finegrained calcareous sandstone forming the upper of the two prominent brown cliffs in the middle of the Bright Angel shale; thin platy beds of finely crystalline buff dolomite containing shells of linguloid brachiopods occur in the upper 5 feet. ................

7. Buff platy sandstone and greenish shale like No. 1 ; beds form slope and ledge between the cliffs of Nos. 6 and 8; some thin beds consist almost wholly of glauconite.

8. Heavy beds of snuff-brown massive crys talline dolomite (for analysis see p. 40), 7 feet; passing down into beds of buff fine-grained cross-bedded glauconitic sandstone, 5 feet; the dolomite and sandstone form the lower of the two brown cliffs in the middle of the Bright Angel shale.................

9. Buff platy sandstone and greenish shale like No. 1; a 4-inch bed of fossiliferous magenta glauconitic sandstone occurs 34 feet above the base; beds form gentle slope.

10. Fossiliferous maventa glauconitic stone, 2 feet, passing up into buff platy quartzitic sandstone, 2 feet; beds form a weak cliff . ..............

11. Buff platy sandstone and greenish shale like No. 1 but containing more platy sandstone in proportion to the shale, so that the beds form a somewhat steeper slope. Beds of magenta sandstone containing hematite, glauconite, and ground-up shells of linguloid brachiopods occur at $16,23,32,34$, and 66 feetabove the base; these beds range in thickness from 1 to 4 inches; part of the hematite occurs as cement between the sand grains; part of it coats the sand grains in tiny concentric layers, giving the rock an oolitic appearance; most of the sand grains are quartz or glauconite but some are pink feldspar; some of the ferritic beds resemble Clinton iron ore.............

[Nоте.-The foregoing section of the Bright Angel shale was measured on the east side of Bass Canyon about half a mile south of Bedrock Tank, at locality 8, figure 2.]

Tapeats sandstone:

A. White to greenish-white cross-bedded sandstone in rather thick beds composed chiefly of clean quartz sand; contains a few lenses of soft greenish sandy shale; lenses of hard sandstone alternate with lenses of softer sandstone which etch out and form alcoves and shelves. The sandstone is speckled with small magenta or brownish spots which represent segregations of ferritic material...

B. Chocolate-colored sandstone in rather thin beds separated by layers of greenish or brownish shale; contains some crossbedded layers, but evenly bedded layers predominate..................

C. Hard chocolate-colored cross-bedded sandstone; commonly a pebbly grit composed chiefly of quartz sand; many beds are indurated to quartzite; small yellow rounded quartz pebbles, the largest the size of peas, are a characteristic constituent; thin lenses of shale are rather abundant in the upper half of the member; the lenses of the shale or softer sandstone etch out and form alcoves and shelves. In many places the lower half of the cliff is incrusted with salt (sodium chloride), and in some protected situations the salt forms stalactites. Lenticular beds of conglomerate from 1 to 15 feet thick occur throughout the sandstone but are more abundant in the basal portion. Some conglomerate beds consist of unassorted angular fragments of the underlying rocks; others consist chiefly of rounded pebbles of quartz. In some places where the sandstone rests against hills of pre-Cambrian rock, beds of coarse breccia occur in the sandstone at the base of the pre-Cambrian hills; one of these beds of breccia exposed in a cliff on the north side of Colorado River, half a mile southeast of the mouth of Bass Canyon, contains blocks of preCambrian quartzite 30 feet in diameter. The Tapeats sandstone rests on an eroded surface which in some places in 
the Shinumo quadrangle exhibits a,relief of nearly 600 feet; consequently the thickness of subdivision $\mathrm{C}$ at any point depends on the topography of the underlying surface. Near the mouth of Bass Canyon, where this section was measured, subdivision $\mathrm{C}$ is 328 feet thick, whereas a mile to the northeast, under Dox Castle, it is absent. The thickness of 250 feet which I have assigned to the subdivision represents approximately the average thickness in Bass Canyon................... \pm 250

[NoTE.-The foregoing section of the Tapeats sandstone was measured west of the mouth of Bass Canyon, at the point where a trail leading from Bedrock Tank to Copper Canyon ascends a break in the cliff formed by the sandstone, at locality 9 , figure 2.$]$

Total thickness of Paleozoic beds...................... \pm 4014

THE PALEOZOIC ROCKS.

CAMBRIAN SYSTEM.

TONTO GROUP.

GENERAL FEATURES.

In the region about Bass Canyon the Tonto group is a series of conformable strata about 1,200 feet thick which lies at the base of the Paleozoic and is separated from underlying pre-Cambrian rocks and from overlying Devonian and Carboniferous rocks by unconformities of erosion. In lithology the group as a whole exhibits a passage upward from sandstone to limestone, roughly in three stages. The strata at the base of the group are sandstones; those in the middle portion are chiefly fine-grained sandstones and sandy shales; and those in the upper portion are more or less sandy calcareous rocks which pass at the top into magnesian limestone. These three lithologic stages afford a natural basis for dividing the group into formations. Accordingly, in a former report describing the region about Bass Canyon ${ }^{7}$ I proposed a threefold division of the Tonto group and used the names Tapeats sandstone, Bright Angel shale, and Muav limestone to designate the formations. The name Tapeats sandstons is applied to the sandstone at the base of the group, the name Bright Angel shale to the sandstone and shale of the middle portion, and the name Muav limestone to the

\footnotetext{
7 Noble, L. F., The Shinumo quadrangle, Grand Canyon district,
} Ariz.: U. S. Geol. Survey Bull. 549, p. 61, 1914. more or less calcareous strata that constitute the upper portion. Walcott had previously adopted a similar threefold division of the Tonto. He states, ${ }^{8}$ "I find among my notes made after the trip to the Grand Canyon in $1901 * * *$ * that I had given names to the three divisions of the Tonto along the same lines that you have, so I can readily agree with your present subdivisions and nomenclature."

At Bass Canyon the three formations are distinct in lithology and in topographic expression, but farther southeast, in the region between the Hermit and Grand View trails, where most visitors see the Grand Canyon, the boundary between the Muav limestone and the Bright Angel shale is indefinite, and the two formations do not appear at first sight to differ conspicuously, whereas the Tapeats sandstone and the Bright Angel shale preserve their distinctive characters and can be distinguished readily. Some uncertainty has therefore existed as to the limits of the Muav limestone in the more frequented part of the Grand Canyon, and the propriety of a threefold division of the Tonto has been questioned.

To determine whether the Muav limestone as defined at Bass Canyon is actually traceable into the region between the Hermit and Grand View trails, I have measured six sections of the Tonto group at different points in the south wall of the Grand Canyon. These sections, spaced from 3 to 8 miles apart, carry the lithology of the Tonto through a distance of about 28 miles southeastward-from Garnet Canyon, 3 miles west of Bass Canyon, to Cottonwood Creek, in the Grand View region-and, in connection with a section measured by Walcott at Nunkoweap Valley, 15 miles north of Cottonwood Creek, carry it practically through the Kaibab division of the Grand Canyon. These seven sections are shown on Plate XX. In addition to recording the Tonto lithology I have represented the unconformity at the summit of the Tonto by indicating diagrammatically the amount of relief which the eroded surface exhibits at each locality, and, where the beds that lie between the unconformity and the Redwall cliff were accessible, I have recorded their character and succession. Owing to lack of space in the drawing I have presented only a brief description of the lithology of each section. The Bass Canyon section is given in

8 Walcott, C. D., personal communication. 
detail in the present report (see pp. 26-36), but an account of the detailed lithology of the other sections is beyond the scope of this paper and will be reserved for another report. In all six sections the Bright Angel shale and Muav limestone were measured by hand level and the Tapeats sandstone was measured by aneroid barometer except at Bass Canyon, where the level was used. The sections at Garnet Canyon, Bass Canyon, Slate Creek, and Hermit Creek are believed to be more accurate than those at Pipe and Cottonwood creeks because they were checked over in detail during a subsequent field trip, whereas the sections at Pipe and Cottonwood creeks were not reviewed.

These sections show that the Muav limestone as defined at Bass Canyon is represented by equivalent beds throughout the Kaibab division, and that the principal subdivisions of the Bass Canyon section preserve enough of their original character to be recognizable in the other localities, although large parts of the formation become sandy southeast of Bass Canyon, the proportion of sandstone to limestone increasing southeastward. The appearance of sandy material in the lower part of the Muav southeast of Bass Canyon makes it increasingly difficult to define exactly the boundary between the Bright Angel shale and the Muav limestone in that direction, as will be shown.

When I proposed the name Muav limestone I used the term "limestone" because in the type locality, near Bass Canyon, the formation as a whole contains more limestone than sandstone and shale. Inasmuch as the formation becomes increasingly sandy southeast of Bass Canyon it may be advisable eventually to change the name to Muav formation, but it seems best to retain the name Muav limestone for the present, until the formation has been studied over a wider area than that covered in this report.

TAPEATS SANDSTONE.

Character.-The Tapeats sandstone is essentially a medium to rather coarse sandstone, grading here and there into a pebbly grit and including beds of conglomerate and shale. The prevailing color is chocolate-brown, although many beds are buff or greenish buff and some beds are pale greenish white. The conglomerate forms lenticular beds that may occur at any horizon in the formation but are more abundant near the base, where as a rule the conglomerate is arkosic and consists of poorly assorted fragments of underlying rocks. Some of the conglomerate, however, is well assorted and consists of rounded pebbles of quartz. Most of the shale occurs above the middle of the formation in thin lenses between layers of sandstone. In general the component materials of the formation become finer and better assorted toward the top. The uppermost beds at Bass Canyon are clean white or greenishwhite cross-bedded sandstone.

Among the distinctive features of the formation are hardness, which causes it to weather into sheer cliffs, prevailing chocolate color, cross-bedding, and a rather coarse horizontal banding due to the fact that the beds form elongated horizontal lenses and differ in texture and hardness. Here and there beds of shale alternate with beds of sandstone, and at most places the sandstone itself, although prevailingly hard, exhibits wide differences in induration. A bed of sandstone which in one place is cemented into compact vitreous quartzite may be poorly consolidated a few hundred feet away. Vertically beds of hard quartzitic sandstone succeed beds of softer sandstone in countless alternations. Erosion etches the bands of softer material into long low alcoves overhung by shelves of harder rock. These shelves and alcoves appear on every outcrop of the Tapeats sandstone and are particularly conspicuous in its great cliff, which is furrowed by tier upon tier of them. (See Pl. XXI, A.) One who is traveling through the canyon along the Tonto platform, or "lower plateau," soon learns to appreciate the shelter which these "Tonto shelves" afford and usually selects them for his camp. Indeed, the selection is almost compulsory, for in most tributary canyons water comes to the surface in the dry watercourses only at the point where the stream channel crosses the summit of the Tapeats sandstone.

Another distinctive feature of the sandstone is the occurrence in many beds of numerous small yellow rounded quartz pebbles, the larg. est of which are the size of peas. Worm markings are common in the white sandstone at the 
top of the Tapeats and occur here and there in the underlying chocolate-colored beds. I have observed ripple marks at a few places in the formation and sun cracks at one place. Glauconite occurs sparingly in scattered grains in some beds.

In many places in the Kaibab division the Tapeats cliff is incrusted with salt. Commonly the deposits are less than an inch thick, but some of them may cover hundreds of square feet. A sample from one of these salt deposits in Garnet Canyon was tested in the laboratory of the Survey and is reported to consist essentially of sodium chloride. A spring that issues from the contact between the Tapeats sandstone and the underlying crystalline rocks at a point about half a mile west of Garnet Canyon yields a heavy brine. Other brine springs issue from this contact at several places in the Kaibab division. The water of the intermittent stream in Garnet Canyon is potable above the middle of the Tapeats sandstone, but below the middle of the sandstone it is too salty to drink. These occurrences indicate that the Tapeats sandstone contains salt, although no beds of salt have been found within the sandstone. Perhaps a small amount of salt is widely distributed in the sandstone but has escaped observation because it is not concentrated in beds. Inasmuch as the Tapeats is a marine deposit the salt is probably an original constituent of the sandstone.

The Tapeats sandstone exhibits little variation from place to place in lithology or in general appearance and is readily identifiable in all parts of the Kaibab division.

Stratigraphic relations.-Both base and summit are well defined, the base by a great angular unconformity that truncates underlying pre-Cambrian rocks and the summit by a rather abrupt change from coarsely banded white cross-bedded sandstone at the top of the Tapeats to thinly laminated even-bedded sandstone and sandy shale at the base of the overlying Bright Angel shale.

Subdivisions.-At Bass Canyon the formation is rudely divisible into three parts. (See Pl. XX.) Subdivision A, at the top of the formation, consists of white cross-bedded sandstone which includes a few layers of greenish shale. Subdivision B, beneath A, consists of evenly bedded chocolate-colored sandstone with partings of shale. Subdivision $\mathrm{C}$, at the base, consists of chocolatecolored cross-bedded sandstone and constitutes by far the greater part of the formation. As the Tapeats sandstone is traced southeastward from Bass Canyon, subdivision A decreases in thickness and becomes more and more like $\mathrm{C}$ in lithologic character until it is practically indistinguishable from $\mathrm{C}$, so that in the three easternmost sections shown on Plate $\mathrm{XX}$ the formation is divisible into only two parts and consists essentially of chocolatecolored cross-bedded sandstone capped by white cross-bedded sandstone. Where hills of pre-Cambrian rock project into the Tapeats sandstone, beds of coarse conglomerate may appear at any horizon in the sandstone where it rests against their steeper slopes, but these conglomerates are local in extent and do not persist many hundreds of feet.

Thickness.-The Tapeats sandstone varies irregularly in thickness from place to place, but the variations have no ultimate stratigraphic significance because the sandstone was deposited upon a surface which, although remarkably even when considered in relation to its vast horizontal extent, is uneven in detail, exhibiting at some places a relief of 600 feet. Thus at the point where the section at Bass Canyon was measured the sandstone attains a thickness of 328 feet, whereas the average thickness in Bass Canyon does not exceed 250 feet; and a mile away, on the north side of Colorado River, where a hill of hard pre-Cambrian strata rises several hundred feet above the general level of the pre-Cambrian surface, the sandstone was not deposited. The thickness assigned to the sandstone at Bass Canyon is exceptional. Perhaps 200 feet would be a fair estimate of the average maximum thickness in the Kaibab division.

Fossils.-No fossils have been found in the Tapeats sandstone except near the top. Schuchert $^{9}$ has noted fragments of an obolid shell in the white cross-bedded sandstone at the top of the formation near Hermit Creek. Walcott ${ }^{10}$ reports the following fauna "in the Tapeats sandstone about 300 feet above its base at the head of Nunkoweap Valley":

9 Schuchert, Charles, The Cambrian of the Grand Canyon of Arizona: Am. Jour. Sci., 4th ser., vol. 45, p. 365, 1918.

10 Walcott, C. D., Cambrian geology and paleontology: Smithsonian Misc. Coll., vol. 64, No. 5, pp. 373, 374, 1916. 
Dolichometopus tontoensis.

Micromitra pealei.

Micromitra (Paterina) crenistria.

Micromitra (Paterina) superba.

Micromitra (Iphidella) pannula.

Obolus zetus.

Obolus (Westonia) chuarensis.

Obolus (Westonia) englyphus.

Lingulella lineolata.

Lingulella perattenuata.

Billingsella obscura.

Alokistocare althea.

According to Walcott the thickness of the Tapeats sandstone at Nunkoweap Valley is 300 feet (see Pl. XX), so that the beds from which he obtained this fauna must lie at the very top of the formation. The age of the fauna is stated to be Middle Cambrian. Practically all the forms listed occur also in the Bright Angel shale.

The age of the summit beds of the Tapeats sandstone is therefore Middle Cambrian. Inasmuch as the formation appears to have been deposited continuously, as is indicated by its homogeneous character, and to have accumulated rapidly, as is indicated by its relatively coarse cross-bedded structure, it is not likely that any part of it is older than Middle Cambrian.

BRIGHT ANGEL SHALE.

Character.-The chief constituent of the Bright Angel shale is fine-grained quartzose micaceous sand, which forms innumerable platy beds mostly less than a quarter of an inch thick. Many beds of sandstone are separated by partings of micaceous sandy shale, and at some horizons the sandstone and shale are associated with dolomitic limestone or with cross-bedded glauconitic sandstone.

The distinctive features of the formation are thin, platy lamination, a prevailingly dull greenish-buff color, the occurrence of glauconite in many beds, and the abundance of wormmarkings and fucoidal casts. Many beds are ripple-marked. Shells of obolid or linguloid brachiopods are abundant at many horizons, and most of the shells are broken and worn, showing marks of grinding and attrition. The ripple marks indicate that the strata were deposited in shallow water, and the broken shells indicate that the deposits were subjected to repeated pounding by waves.

The formation as a whole is the least resistant to erosion of all the formations in the can- yon wall. It makes a more or less continuous slope, which at most places has retreated far back from the summit of the Tapeats cliff, leaving the so-called "lower plateau," or Tonto platform. It owes its weakness to the alternations of shale and sandstone and to the thin platy lamination of the beds. Actually most of the platy sandstone is well indurated, and some of it is as compact as quartzite.

Glauconite is decidedly more abundant in the Bright Angel shale than in the other two formations of the Tonto group. It occurs rather sparingly in most beds in tiny grains scattered through the rock but is widely distributed in the formation, both vertically and horizontally. Apparently no beds consist entirely of glauconite, but an examination of the formation anywhere in the Kaibab division of the Grand Canyon will disclose a few beds several inches thick in which nearly half of the rock is glauconite and many beds in which the grains are sufficiently abundant to impart a greenish tinge to the rock. The mineral is not confined to the prevailing platy sandstone and shale but occurs in the dolomite, intraformational conglomerate, and cross-bedded sandstone described below. An interesting feature of its occurrence is its association with deposits that were obviously laid down in shallow water.

Interbedded with the platy sandstone and shale are two types of rock which, although they form only a subordinate part of the Bright Angel shale, are particularly characteristic of the formation.

One of these rocks is a compact crystalline limestone whose color is deep snuff-brown on weathered surfaces and pale tan on freshly broken surfaces. Beds of this limestone are very resistant to erosion and make cliffs. In the region about Bass Canyon two beds vertically 35 feet apart appear in the Bright Angel shale at a horizon about 125 feet above its base and make two conspicuous brown cliffs in the slope above the Tonto platform. Each cliff is about 12 feet high. The beds of snuffbrown limestone, which determine the cliffs, range in thickness from a few inches to 8 feet and are associated with beds of green, magenta, and brown cross-bedded sandstone. The cliffs are sharply defined and are wonderfully persistent. (See Pl. XXI, B.) Wherever possible the Tonto trail in this part of the canyon follows 
the narrow ledge at the top of one or the other of these cliffs, because the ledges afford much smoother going than the dissected and débriscovered slopes of the Tonto platform below. Other beds of snuff-brown limestone appear in the Bright Angel shale between the twin cliffs just described and the base of the Muav limestone, but at Bass Canyon they are thin and do not make conspicuous cliffs. Most of them are associated with beds of greenish and magenta cross-bedded sandstone.

The snuff-brown limestone effervesces weakly with acid. Some beds contain no visible impurities, but others contain scattered grains of glauconite and tiny rounded grains of quartz and exhibit cross-bedding. Many beds contain broken shells of brachiopods. In places the limestone passes laterally into an intraformational conglomerate composed chiefly of rounded, flattened fragments of limestone but containing glauconite, quartz sand, and broken shells.

The following analysis of a specimen of the snuff-brown limestone forming the lower of the twin cliffs at Bass Canyon (see p. 35) probably represents approximately the composition of the purer limestone. The bed from which the specimen was taken contains no visible glauconite or quartz and appears to consist entirely of coarsely crystalline limestone.

Partial chemical analysis of snuff-colored limestone from Bright Angel shale.

[Alfred A. Chambers, analyst.]

Insoluble......................... 2.66

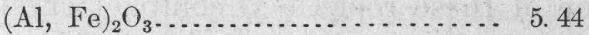

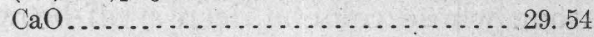

$\mathrm{MgO} \ldots \ldots \ldots \ldots \ldots \ldots \ldots \ldots \ldots . . \ldots \ldots . .18 .26$

From this analysis it appears that the rock is an impure dolomite. The presence of quartz grains in beds closely associated with the one analyzed suggests that the insoluble impurities are largely quartz sand, and the fact that the rock weathers brown suggests that the other impurities are largely iron. Inasmuch as the snuff-colored limestones effervesce weakly with acid and differ from one another chiefly in the amount of impurities that they contain I have called them all dolomites in this report.

Another characteristic rock in the Bright Angel shale is dark-green or magenta crossbedded sandstone. Most of this sandstone forms rather massive beds, which range in thickness from a few inches to several feet. The component grains are rather coarse and in most beds are loosely cemented, so that the rock crumbles easily. Some beds, however, form weak cliffs. The chief constituent of the sandstone is quartz, but many beds contain glauconite and many contain a large amount of ferritic sandy mud and more or less hematite. Broken shells of brachiopods are abundant in some beds. These green and magenta sandstones are readily distinguishable from the prevailing platy sandstone by their deep colors, cross-bedding, absence of thin lamination, and relatively coarse texture. The colors of some beds are very striking, green shading into deep bottle-green and magenta into deep purplish brown. In places these colors are mingled in blotches in the same bed, producing a curious mottled effect. The greenish beds owe their color largely to glauconite, and the magenta beds owe theirs to ferritic material. Some beds associated with snuff-colored dolomite weather brown.

At Bass Canyon the thickness of the Bright Angel shale is 391 feet and I have divided it into two members-subdivision A, at the top, 58 feet thick, and subdivision B, below, 333 feet thick. Both subdivisions consist essentially of thin-bedded greenish and buff micaceous shale and sandstone, with which snuff-brown dolomite and greenish and magenta sandstone of the types just described are interbedded at irregular intervals. The character and succession of the beds are recorded in the columnar section (pp. 34-35). In general composition subdivision $\mathrm{A}$ differs from $\mathrm{B}$ only in that it contains, near the base, a few beds of mottled limestone similar to those which constitute subdivision D of the overlying Muav limestone. In a former report ${ }^{11} \mathrm{I}$ included subdivision $\mathrm{A}$ in the Muav limestone, placing the base of the Muav at the lowest point where mottled limestone appears in the Tonto group, but in the present report I have included subdivision A in the Bright Angel shale, which as here defined includes all strata between the white cross-bedded sandstone at the top of the Tapeats and the cliff-making gray and buff mottled limestone that constitutes subdivision D of the Muav. This definition is in accord with Walcott's observations at Kanab Creek. Wal-

11 Noble, L. F., op. cit., p. 65. 


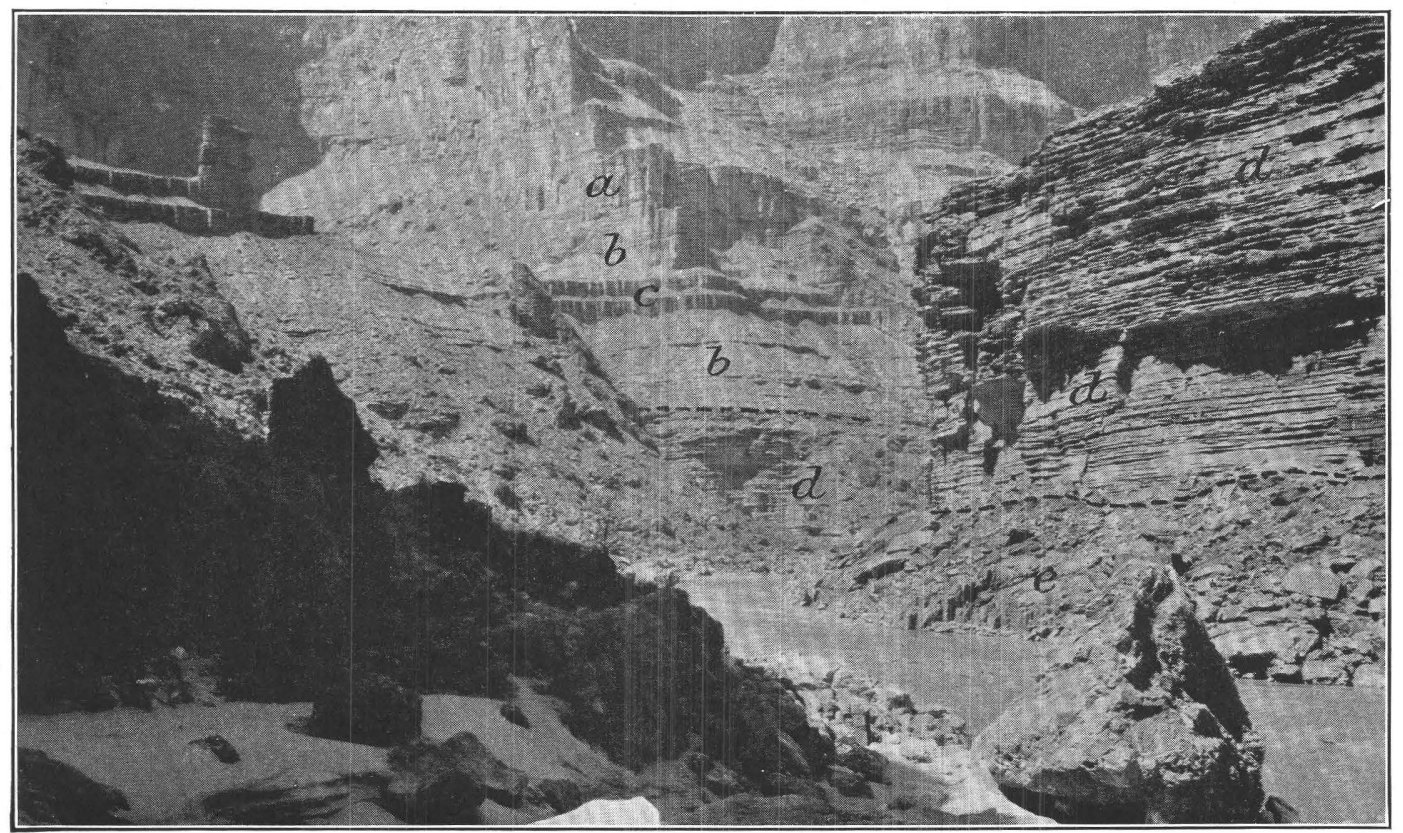

A. TYPICAL EXPOSURE OF TAPEATS SANDSTONE ON COLORADO RIVER OPPOSITE MOUTH OF ELVES CHASM, SHINUMO QUADRANGLE, ARIZ.

$a$, Muav limestone; $b$, Bright Angel shale; $c$, twin cliffs of snuff-colored dolomite of Bright Angel shale; $d$, Tapeats sandstone; $e$, Vishnu schist.

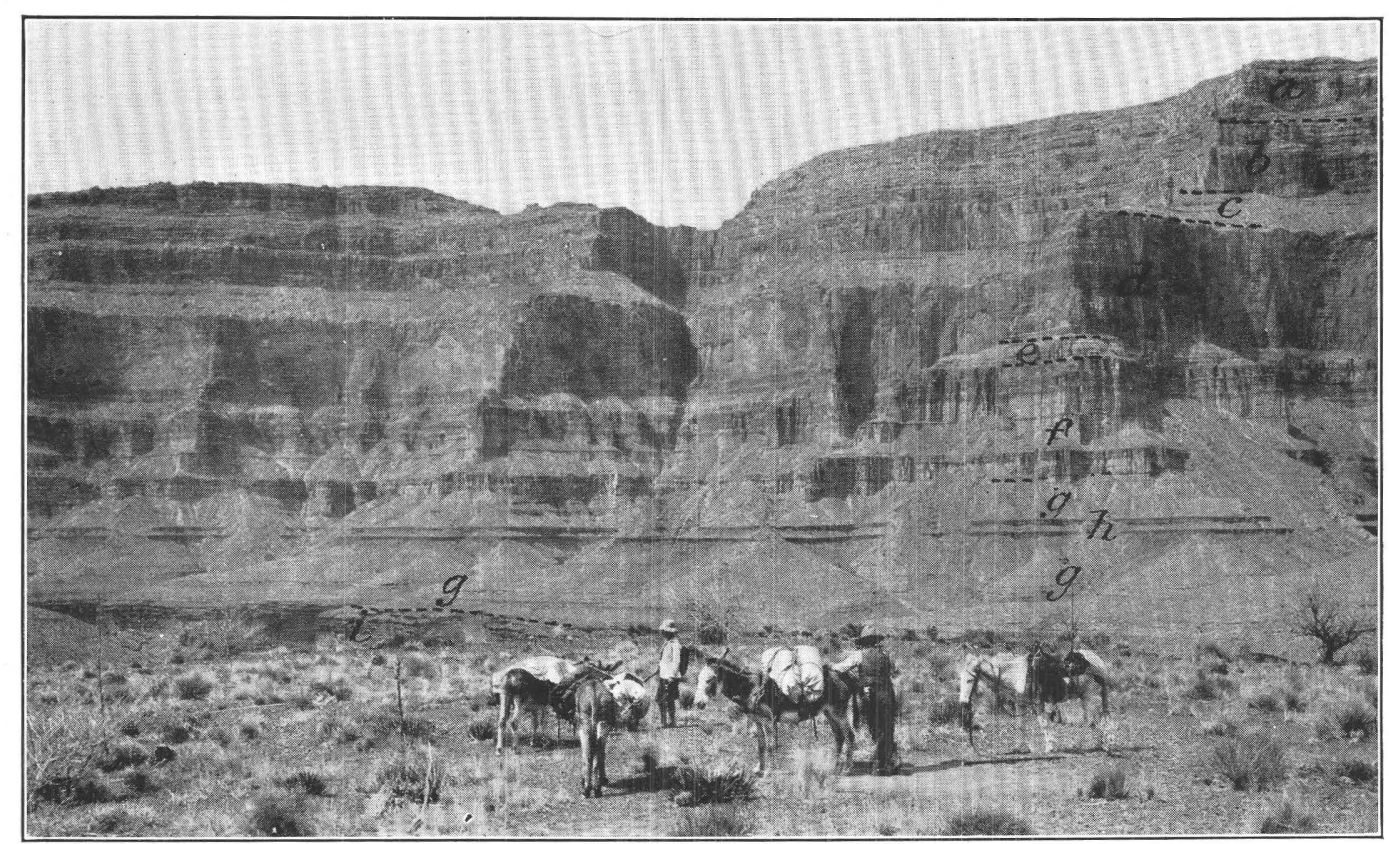

B. TYPICAL EXPosure of BRIGHT ANGEL SHALE, MUAV LIMESTONE, TEMPle BUTTE LIMESTONE, REDWALL LIMESTONE, AND SUPAI FORMATION IN NORTH WALL OF GRAND CANYON OPPOSITE GARNET CANYON, SHINUMO QUADRANGLE, ARIZ.

$a, b, c$, Supai formation, subdivisions $\mathrm{A}, \mathrm{B}, \mathrm{C} ; d$, Redwall limestone; $e$, Temple Butte limestone; $f$, Muav limestone; $g$, Bright Angel shale; $h$, twin cliffs of snuff-colored dolomite in Bright Angel shale; $i$, Tapeats sandstone. 

cott's section at Kanab Creek (see Pl. XX) shows 100 feet of greenish micaceous shale and sandstone (d) beneath beds of mottled limestone (c) that are evidently equivalent to subdivision D of the Muav limestone of my Bass Canyon section. He states ${ }^{12}$ that a mile or two east of Kanab Creek, where more of the greenish micaceous shale and sandstone (d) is exposed, the shale and sandstone pass downward into mottled gray limestone, calcareous and micaceous shale, and dark indurated sandstone. Probably this mottled gray limestone is equivalent to the mottled limestone that appears in thin beds at the base of subdivision A of the Bright Angel shale in my Bass Canyon section, so that subdivision d of Walcott's section at Kanab Creek is roughly equivalent to my subdivision A at Bass Canyon. Walcott states ${ }^{13}$ : "I find on my locality label 75 that the thin-bedded sandstone and shale (d) at Kanab Creek is placed in the Bright Angel shale and the overlying mottled limestone (c) in the Muav limestone."

The columnar sections of the Tonto group shown on Plate XX trace the lithology of the Bright Angel shale through the greater part of the Kaibab division. They show that although the formation exhibits little change in general composition from place to place the interbedded layers of green and magenta sandstone and snuff-colored dolomite increase in number and become thinner and more widely distributed through the prevailing platy sandstone and shale toward the southeast. This change is shown clearly in the profiles of the different sections. Thus, at Garnet and Bass canyons the formation contains only two prominent sets of beds of green and magenta sandstone and snuff-brown dolomite, so that only two cliffs break the long slope formed by the platy beds. But southeast of Bass Canyon, at Slate, Hermit, and Pipe creeks, two other sets of beds of sandstone and dolomite have appeared above the lower pair, so that the slope is broken by four cliffs instead of two. These four cliffs are strongly defined at Slate Creek, fairly well defined at Hermit Creek, and poorly defined at Pipe Creek because the beds become thinner toward the southeast. Southeast of Pipe Creek, at Cottonwood Creek, these beds are so widely distributed in the platy sandstone and

12 Walcott, C. D., unpublished notes.

13 Personal communication. shale and are all so thin that no bed or set of beds makes a prominent cliff. Here the whole formation presents a continuous slope. Three miles east of Cottonwood Creek, at "Congress Canyon" (Red Canyon), that part of Frech's section of the Tonto group ${ }^{14}$ which represents the Bright Angel shale is similar in lithology to my section of the Bright Angel shale at Cottonwood Creek.

Southeast of Bass Canyon beds of green and magenta sandstone are more abundant in the Bright Angel shale than beds of snuff-colored dolomite. In the region between Slate and Pipe creeks these sandstones have attracted attention as a possible source of platinum and at one time were extensively prospected. No samples of the rock examined by the Survey have yielded platinum, but some of the rock when crushed and panned yields a small amount of magnetite. At Slate Creek some of these sandstones, near the base of the Bright Angel shale, contain considerable hematite and form thin beds that are conspicuous by their bright-red color. Between Bass Canyon and Garnet Canyon some ferritic beds at this horizon exhibit oolitic structure. (See p. 35.)

Probably the beds of snuff-brown dolomite and sandstone that make the twin cliffs at Bass and Garnet canyons are traceable far west of the area covered by the present report, because a section of the Bright Angel shale at the mouth of the Grand Canyon ${ }^{15}$ shows a double cliff of snuff-colored sandstone that is said to be continuous throughout the Shivwits division, Gilbert having traced it from the Grand Wash to Diamond Creek.

Southeastward from Bass Canyon the thin beds of mottled limestone at the base of subdivision A gradually give way to calcareous sandy shale and finally disappear southeast of Hermit Creek.

Few hills of pre-Cambrian rock rise far into the Bright Angel shale, but one hill on the north side of Colorado River about 3 miles east of Bass Canyon rises nearly to the top of subdivision B. So far as known, this is the highest hill of pre-Cambrian rock in the Grand Canyon.

Thickness.-The thickness of the Bright Angel shale decreases gradually from northwest

14 Frech, F., Cong. géol. internat., 5e sess., Compte rendu, p. 479.

15 U. S. Geog. and Geol. Surveys W. 100th Mer. Rept., vol. 3, p. 199, figs. $86,87,1875$. 
to southeast. Thus the formation is 402 feet thick at Garnet Canyon, 391 feet at Bass Canyon, 392 feet at Slate Creek, 344 feet at Hermit Creek, 325 feet at Pipe Creek, and 334 feet (estimated) at Cottonwood Creek. At Nunkoweap Valley, 15 miles north of Cottonwood Creek, it is 325 feet thick. The beds equivalent to subdivision A of the Bass Canyon section decrease from 60 feet at Garnet Canyon to 42 feet at Pipe Creek, and the beds equivalent to subdivision B decrease from 342 feet at Garnet Canyon to 283 feet at Pipe Creek. At Cottonwood Creek the two subdivisions can not be separated with certainty.

Fossils.-Fossils are abundant at several horizons in subdivision B of the Bright Angel shale. The following species listed in my report on the geology of the Shinumo quadrangle ${ }^{16}$ were collected by Walcott or by me at several horizons in subdivision B in the region about Bass Canyon and Shinumo Creek:

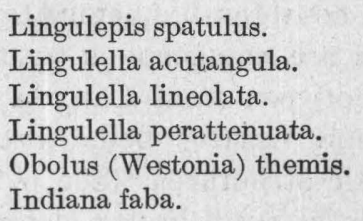

At 25 feet above the base of subdivision B in Serpentine Canyon I have collected and Edwin Kirk has identified Micromitra (Paterina) superba and Lingulella lineolata, and at 165 feet above the base of subdivision B near Hermit Creek Obolus (Westonia) chuarensis and Micromitra (Iphidella) pannula.

At 100 to 120 feet above the base of subdivision B near the Bright Angel (Cameron) trail Walcott ${ }^{17}$ has collected the following species:

Obolus (Westonia) chuarensis.

Eocystites? undet. sp.

Hyolithes.

Alokistocare althea.

Dolichometopus productus.

Dolichometopus tontoensis.

The age of this fauna is stated by Walcott to be Middle Cambrian.

In 1915 Schuchert studied the Bright Angel shale at Hermit Creek and collected fossils at several horizons. He states ${ }^{18}$ :

When the sandy muds were forming, seaweeds (Palaeophycus) were common, along with a great abundance of burrowing annelids. Trailings and fucoidal casts are

\footnotetext{
${ }_{16}$ Noble, L. F., op. cit., p. 64.

17 Walcott, C. D., Cambrian geology and paleontology: Smithsonian Misc. Coll., vol. 64, No. 5, p. 374, 1916.

18 Schuchert. Charles, op. cit., p. 367.
}

nearly always to be seen, and also the vertical burrowings of worms like Arenicolites. * * * In spite of the fact that almost no good fossils are to be had in the Bright Angel formation, yet the physical phenomena show that the epeiric sea of this time must have been rich in life. This is proved by the abundance of fucoidal casts, trailings, and annelid burrows. Further, in some of the sandstones obolid fragments teem, and at times their shells make up one-third of a stratum. When the obolid shells are prevalent, glauconite is also common, and the formation of this mineral is probably conditioned by the decomposition of the organic remains. On the other hand, there are entire beds of glauconite up to a few inches thick that are almost devoid of fossils. When glauconite is very abundant, there are also apt to be thin beds and even zones a few feet thick of low-grade iron ore.

Palaeophycus casts are very common and well preserved at 15 feet above the Tapeats sandstone, and 150 feet higher is a glauconitic sandstone replete with the brachiopods Micromitra (Iphidella) pannula (White) and Obolus (Westonia) chuarensis. Ten feet higher occur abundantly in thin-bedded sandstones Obolus zetus and rarely Obolus (Westonia) themis and Lingulella acutangula.

The most prominent horizon for fossils, consisting almost entirely of obolids, is the one just mentioned, which occurs from 150 to 170 feet above the base of the Bright Angel formation and is at the same time a general level for thin-bedded sandstones.

It is evident that the age of at least the lower 170 feet of subdivision B of the Bright Angel shale is Middle Cambrian, as shown by fossils. I have found no determinable fossils in the upper part of the subdivision but have noted in a bed near the top small fragments of obolid shells similar to those that occur in the lower 170 feet. I have found no fossils in subdivision A at Bass Canyon, nor in beds that occupy the equivalent horizon at localities where I measured the other Tonto sections. But inasmuch as subdivision A differs in general lithologic character from subdivision $\mathrm{B}$ only in that it contains a few layers of mottled limestone, which gradually disappear east of Bass Canyon, and is evidently equivalent to a set of beds at Kanab Creek in which Walcott has found Middle Cambrian fossils and which he includes in the Bright Angel shale (see p. 41), I believe the entire Bright Angel shale as defined in this report is Middle Cambrian.

\section{MUAV LIMESTONE.}

Character.-At Bass Canyon the Muav limestone consists chiefly of impure limestone and calcareous sandstone but includes much platy sandstone and shale that do not differ from those which occur throughout the Bright Angel shale. Platy or shaly lamination is a prominent feature except at the top of the formation, but 
unlike the Bright Angel shale the Muav, as a whole, is fairly resistant to erosion and makes cliffs or steep slopes. The prevailing rock is a peculiar gray and buff mottled limestone, which occurs in countless beds averaging less than an inch thick. The lower two-thirds of the formation consists largely of this mottled limestone and partly of platy sandstone and shale; the upper third consists of calcareous sandstone overlain by massive magnesian limestone.

Subdivisions.-At Bass Canyon four subdivisions with persistent features can be differentiated, although the boundaries between them are not sharp. The massive magnesian limestone at the top of the Muav constitutes subdivision A, 63 feet thick, and forms a strong cliff. The underlying calcareous sandstone constitutes subdivision $B, 72$ feet. This sandstone, massive at the top but thin-bedded at the base, makes a set of weak cliffs that in most places unite with the cliff formed by the overlying limestone. Beneath subdivision B is 241 feet of thin-bedded mottled limestone containing many interbedded layers of platy sandstone and shale. These alternating beds constitute subdivision $\mathrm{C}$ and form a steep slope. Beneath them is a cliff-making bed of relatively pure mottled limestone 97 feet thick, which constitutes subdivision D, at the base of the Muav.

In appearance the mottled limestone of the Muav is unlike any other rock in the Paleozoic section. Characteristically it is a hard thinbedded impure limestone, whose outcrops when seen from a distance resemble outcrops of shale. The beds range in thickness from less than an eighth of an inch to several inches but commonly do not exceed half an inch. The purer limestone is gray, but most of the rock contains a considerable amount of buff material which was originally a fine-grained micaceous sandy mud. Some of this material forms shaly partings between the beds of limestone, and some of it is mixed with the limestone, so that in most beds the gray and buff colors are mingled. Many limestone beds are intraformational conglomerates composed of small flattened rounded pebbles of mottled limestone embedded in a matrix which in some places consists of crystalline limestone and in others of buff calcareous material. Nearly every bed of limestone or conglomerate exhibits numerous coralloid or fucoidal markings. These markings, which Newberry and other early observers ascribed to branching corals but which Schuchert and Walcott have shown to be largely the work of worms, are one of the distinctive features of the mottled limestone. Schuchert ${ }^{19}$ states:

Where the calcareous materials become more dominant the beds are completely riddled with vertical and anastomosing worm burrows. These are usually filled with a very fine sand, and it is this feature that gives so much of the Muav its mottled appearance and that led Gilbert many years ago to call the formation in the western part of the Grand Canyon the "mottled limestone." Throughout the middle third of the Muav many of the shaly limestones are intraformational conglomerates with the pebbles small, flat, and more or less rounded on the edges. It is an interesting shallow-water, near-shore marine deposit. This is shown in the great abundance of annelid burrows, in the intraformational conglomerates, and in the variable nature of the calcareous deposits. * * * The writer has not seen a Paleozoic marine deposit more bored into and consumed by mud eaters than this one, and these burrows are most prevalent in the calcareous zones. Worm castings are often well preserved in the thin-bedded shale zones and occur as little confused heaps or in circular sausage-like strings, .

Most beds of the mottled limestone effervesce freely with acid. An analysis of a typical specimen from a bed that exhibits the usual mixture of gray limestone and buff sandy material is given below.

Partial chemical analysis of mottled limestone from Muav limestone.

[Albert A. Chambers, analyst.]

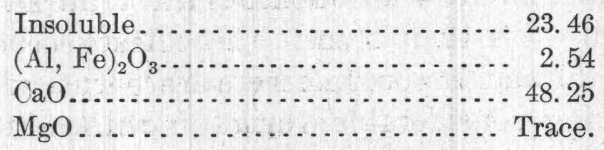

This analysis shows that the limestone is not magnesian and indicates that the sandy impurities constitute about a quarter of the rock.

Subdivision D, at the base of the Muav, consists almost wholly of the thin-bedded mottled limestone just described and contains very little limestone of the intraformationalconglomerate type. In the basal 10 feet of the subdivision thin layers of fine-grained platy sandstone are interbedded with the limestone. These alternating beds define the lower limit of the Muav limestone, and their separation from the underlying greenish shale and platy sandstone of the Bright Angel shale is distinct at Bass Canyon, although they represent a transition in lithology rather than an abrupt change. Owing to the hardness of the mottled limestone subdivision D forms a strong cliff, a feature

${ }_{19}$ Schuchert, Charles, op. cit., pp. 368,369 
which at once distinguishes it from the overlying subdivision $\mathrm{C}$ and from the underlying Bright Angel shale, which forms slopes. Just beneath the cliff are the soft underlying greenish shale and sandstone, which persist over a considerable area east and west of Bass Canyon and etch out everywhere, leaving a small alcove overhung by the cliff. The alcove will guide the observer to the contact between the Bright Angel shale and the Muav limestone.

Subdivision C consists chiefly of thin-bedded mottled limestone but unlike subdivision D contains many thin interbedded layers of sandstone and shale. The character and succession of the strata, which are variable in composition and occur in countless alternations, are shown in the detailed section on pages 33-34. Some parts of the subdivision contain as much sandstone and shale as mottled limestone, but other parts contain considerably more mottled limestone than any other rock, and large parts consist almost entirely of mottled limestone. The mottled limestone in subdivision C, unlike that in the underlying subdivision, is chiefly of the intraformational-conglomerate type. In general the beds contain more worm markings than those of subdivision D and vary more in thickness and composition. Some beds attain a thickness of a foot or more, and many are from 4 to 6 inches thick, although most are less than 1 inch. The thicker beds of intraformational conglomerate are lenticular, exhibiting considerable variation within horizontal distances of a few hundred feet. Glauconite occurs sparingly in some strata. Most of the interbedded sandstone and shale resemble those which prevail in the Bright Angel shale. Thesandstone is fine grained, quartzose, and micaceous and occurs in thin platy layers; the shale is greenish, soft, micaceous, and sandy. Some of the sandstone, however, is calcareous and resembles that which occurs in the overlying subdivision B. A prominent bed of hard brownish-buff cross-bedded calcareous sandstone 8 feet thick appears at a horizon 142 feet above the base of subdivision C and makes a small conspicuous and persistent brown cliff that is traceable over many miles in the region about Bass Canyon. Other beds of calcareous sandstone are interbedded with intraformational conglomerate and platy quartzose sandstone at the top of the subdi- vision. Some of these upper beds exhibit purplish spots and mottlings similar to those which appear in the rocks of subdivision B, and some of the intraformational conglomerates are purplish.

Subdivision B consists chiefly of fine-grained calcareous sandstone but includes beds of platy quartzose sandstone, sandy micaceous shale, crystalline limestone, dolomite, and intraformational conglomerate. The prevailing color of the strata is pale buff, but pinkish, purplish, and greenish hues occur. Many beds contain pinkish or purplish blotches and mottlings. The upper portion of the subdivision is relatively thick bedded, many beds attaining a thickness of 2 feet or more. The lower portion contains some beds as much as 1 foot thick but in general is thin bedded. Toward the base the lamination becomes shaly and many layers are as thin as cardboard. Most of the subdivision forms a cliff or a steep ledgy slope broken by cliffs.

The typical calcareous sandstone is hard, compact, and fine grained, effervesces with acid, and is easily scratched with a knife. Weathered surfaces feel gritty and display indistinct cross-bedding, although freshly broken surfaces may exhibit no cross-bedded structure. Some beds are crystalline and consist entirely of calcareous material. Others contain more or less fine quartzose and micaceous sand. It is difficult to decide whether to classify some beds as limestone or as calcareous sandstone, but the cross-bedded structure indicates that the component material, whatever its composition, is of clastic origin.

The upper half of the subdivision is composed largely of the calcareous sandstone just described. Here and there a bed of pinkish or purplish crystalline limestone is interbedded with the calcareous sandstone. Beds of fine quartzose sandstone, sandy shale, and intraformational conglomerate appear at several horizons, and near the top of the subdivision there is a bed or two of dolomite similar to that in the overlying subdivision A. The lower half of the subdivision is composed partly of calcareous sandstone and partly of platy quartzose micaceous sandstone, sandy micaceous shale, and intraformational conglomerate. Worm markings are abundant, and some beds exhibit sun cracks and ripple marks. Scat- 
tered grains of glauconite occur in some beds. Most beds in the lower part of the subdivision do not effervesce with acid.

Although intraformational conglomerate may appear at any horizon in subdivision $\mathrm{B}$ it does not form thick sets of beds and is not abundant in the subdivision as a whole. Most of it differs in composition from the conglomerate in the underlying subdivision in that, although composed chiefly of small flattened rounded pebbles, it is not essentially a limestone. Most of the pebbles are fine-grained sandstone, and the matrix is fine sand.

Subdivision A, at the top of the Muav, consists of hard buff limestone which forms massive beds from 2 to 10 feet thick. Thin partings of sandy shale separate some beds. The limestone is entirely crystalline and exhibits no bedded structure on freshly broken surfaces, but weathered surfaces show faint traces of cross-bedding. Most of the rock contains small cavities, some of which are filled with crystalline material. Some beds exhibit purplish blotches and mottlings. Most beds do not effervesce with acid, although some effervesce feebly. The following analysis shows the composition of a typical specimen of the limestone from a bed 15 feet above the base of the subdivision in Bass Canyon.

Partial chemical analysis of limestone from subdivision $A$, Muav limestone.

[Alfred A. Chambers, analyst.]

Insoluble..................... 1.52

$(\mathrm{Fe}, \mathrm{Al})_{2} \mathrm{O}_{3} \ldots \ldots \ldots \ldots \ldots \ldots \ldots \ldots \ldots . . .6 . .80$

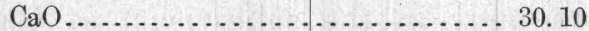

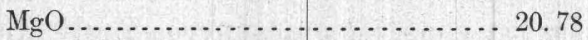

From this analysis it appears that the rock is a magnesian limestone that differs little in composition from typical dolomite. The small amount of insoluble material which the rock contains suggests that if, as the indistinct crossbedding indicates, the rock was composed originally of detrital sand, the sand was calcareous, not siliceous.

These massive dolomites of subdivision A are the most resistant strata in the Tonto group and in eonsequence of their hardness weather everywhere into strong cliffs. In appearance they are wholly unlike the thin-bedded strata of the Bright Angel shale and lower Muav, resembling rather beds at the base of the great cliff formed by the Redwall limestone. How- ever, they are separated from the Redwall cliff in Bass Canyon by 75 feet of thinly laminated beds that form a slope, so that the observer will experience no difficulty in distinguishing them from the Redwall strata. The upper limit of subdivision A is an unconformity of erosion, which is described on pages 49-51.

Thickness and correlation.-The columnar sections in the Kaibab division of the Grand Canyon (see Pl. XX) in connection with Walcott's section at Kanab Creek (see Pl. XIX) trace the lithology of the Muav limestone through a distance of 50 miles southeastward. These sections show that the formation thins steadily from northwest to southeast. The thickness at Kanab Creek is 685 feet; at Garnet Canyon, 504 feet; at Bass Canyon, 473 feet; at Slate Creek, 429 feet; at Hermit Creek, 419 feet; at Pipe Creek, 383 feet; and at Cottonwood Creek (estimated), 238 feet. At Nunkoweap Valley the thickness is 425 feet, but this locality is 15 miles north of Cottonwood Creek. Thus the formation loses about two-thirds of its thickness in the 50 miles between Kanab Creek and Cottonwood Creek. The thinning is due primarily to decrease in deposition, not to erosion, although at some places-for example, at Cottonwood Creek-more beds have been removed below the erosional unconformity at the top of the Muav than at others.

The chief lithologic units into which the formation is divisible at Bass Canyon are recognizable in all the other sections, although it is difficult to trace from one locality to another the exact boundaries that limit the subdivisions, because the strata undergo gradual changes in composition from place to place and the subdivisions grade into one another vertically. Broadly the lower two-thirds of the formation everywhere is thin bedded and consists of mottled limestone and interbedded sandy material, whereas the upper third is comparatively thick bedded and consists of calcareous sandstone below and massive limestone above. Large parts of the formation, however, bécome increasingly sandy toward the southeast. At Kanab Creek the formation consists chiefly of limestone, whereas at Cottonwood Creek, 50 miles southeast of Kanab Creek, and at Nunkoweap Valley, 15 miles north of Cottonwood Creek, it consists chiefly of calcareo-arenaceous rocks. 
Most of the lithologic change occurs in subdivisions $\mathrm{C}$ and D. (See Pl. XX.) Thus at Bass Canyon subdivision $\mathrm{D}$, at the base of the Muav, is 97 feet thick and consists almost wholly of mottled limestone. Only 10 feet of limestone, at the base of the subdivision, contains interbedded layers of sandstone. At Slate Creek, southeast of Bass Canyon, the mottled limestone of subdivision D is 50 feet thick, and the basal 44 feet of the subdivision is made up of alternating beds that consist chiefly of sandstone and shale but include a few layers of mottled limestone. That these prevailingly sandy beds are actually a part of subdivision $\mathrm{D}$ as defined at Bass Canyon and are not equivalent to beds included in the Bright Angel shale at Bass Canyon is clear, because the conspicuous soft green shale that marks the upper limit of the Bright Angel shale at Bass Canyon (see p. 34) is traceable continuously from Bass Canyon to Slate Creek. At Hermit Creek the mottled limestone of subdivision $\mathrm{D}$ is 40 feet thick and the underlying sandy beds 42 feet; and at Pipe Creek, still farther southeast, the mottled limestone is 34 feet thick and the sandy beds 51 feet. At the last two localities the mottled limestone interbedded with the sandy beds is very impure, so that the beds do not differ conspicuously from the Bright Angel shale and are difficult to separate from it. At Cottonwood Creek, southeast of Pipe Creek, the mottled limestone at the top of subdivision D is only 25 feet thick and overlies beds of greenish sandstone which contain layers of impure mottled limestone in the upper 17 feet. Here I have placed the base of subdivision $\mathrm{D}$ at a point 37 feet below the 25 -foot bed of mottled limestone. This horizon, as nearly as I could determine, is equivalent to that which marks the top of the Bright Angel shale at Bass Canyon, but the horizon is not actually traceable between Bass Canyon and Cottonwood Creek. Probably, however, my estimate of its position at Cottonwood Creek is correct within 25 feet.

West of Bass Canyon, at Garnet Canyon, the mottled limestone is 122 feet thick and occupies all of subdivision D. A few thin layers of sandy material are interbedded with the basal 6 feet of the limestone.

Thus subdivision D decreases in thickness and undergoes a gradual change in composition southeastward through the Kaibab division.
It decreases from 122 feet at Garnet Canyon to 62 feet at Cottonwood Creek, 28 miles southeast of Garnet Canyon. At Garnet Canyon it consists almost entirely of mottled limestone; at Cottonwood Creek it contains only a third as much mottled limestone as sandstone and shale, the limestone measuring only 25 feet. The increase of sandy material in the lower part of the subdivision makes its separation from the Bright Angel shale increasingly difficult southeast of Bass Canyon.

Subdivision C, like subdivision D, decreases in thickness southeastward. At the type locality, at Bass Canyon, it is 241 feet thick. Southeast of Bass Canyon equivalent beds are 225 feet thick at Slate Creek, 215 feet at Hermit Creek, 185 feet at Pipe Creek, and 176 feet at Cottonwood Creek. These correlations are necessarily approximate, because subdivision $\mathrm{C}$ is nowhere separated from the overlying and underlying subdivisions by sharp lithologic changes, but in general the limits of the beds correlated with subdivision $\mathrm{C}$ are believed to be correctly placed within 25 feet. At all localities the subdivision is prevailingly calcareous but variable in composition, thin beds of mottled limestone, in traformational conglomerate, sandstone, and shale succeeding one another in countless alternation, yet it contains much more limestone in proportion to sandy material at Garnet Canyon than at Cottonwood Creek and thus, like subdivision $\mathrm{D}$, becomes increasingly sandy toward the southeast. Glauconite, which occurs sparingly in the subdivision at Garnet and Bass canyons, becomes increasingly abundant southeast of Bass Canyon.

Subdivisions C and D together constitute that part of the Muav limestone in which thin-bedded mottled limestone is the prevailing rock and occupy the lower two-thirds of the formation. I have separated them at Bass Canyon, (1) because at that locality subdivision D consists essentially of mottled limestone, whereas subdivision $\mathrm{C}$ includes many interbedded layers of sandstone and shale; (2) because practically no limestone in subdivision $\mathrm{D}$ is of the intraformational-conglomerate type, whereas most of the limestone in subdivision $\mathrm{C}$ is intraformational conglomerate; and (3) because the two subdivisions differ in topographic expression, D forming a cliff and $\mathrm{C}$ forming a slope. Walcott in his sections at 
Kanab Creek and Nunkoweap Valley (see Pls. XIX and XX) does not subdivide this part of the Muav in which mottled limestone is the prevailing rock.

The mottled limestone at Kanab Creek is described by Walcott ${ }^{20}$ as follows:

\begin{abstract}
The limestone is hard and brittle, breaking into angular fragments. Arenaceous shaly partings occur at various horizons, and there is considerable arenaceous detrital matter mixed with the limestone. At the base a massive bed 70 feet in thickness occurs, which is followed by several hundred feet of thin-bedded limestones. Many layers are gray limestone full of small flattened fragments [intraformational conglomerate?]. Toward the summit the upper 85 feet is essentially a repetition of the 70 feet at the base. The entire mass has a thickness of 450 feet. The coralline mottling, as it has been called by authors, extends from base to summit. That a portion of the mottling is produced by the former presence of branching corals may be true, but that such is usually the case is questioned. A study of the various forms of ramifying annelid trails and borings in the shales beneath prepares us to look for the origin of the mottling in that direction. On the surface of the intercalated arenaceous shales and also of the shaly sandstone layers these trails are seen in abundance. They may be traced into the limestone from the surface. Where the matrix is arenaceous they are frequently calcareous, and in the calcareous layers they are often silicified. Usually of a purplish color, they may be gray or buff according to the material by which they have been replaced. *** I should assign to annelids by far the greater share in the origin of the mottling of the limestone.
\end{abstract}

The 450-foot mottled-limestone member just described constitutes subdivision $\mathrm{c}$ of Walcott's section at Kanab Creek and is undoubtedly roughly equivalent to subdivisions $\mathrm{C}$ and D of my Bass Canyon section. At Nunkoweap Valley it constitutes subdivision 3 of Walcott's section, is 340 feet thick, and is a series of mottled and variegated calcareoarenaceous rocks. Thus it decreases from 450 feet at Kanab Creek to 338 feet (the aggregate thickness of subdivisions $\mathrm{C}$ and D) at Bass Canyon, 30 miles southeast of Kanab Creek. Between Bass Canyon and Nunkoweap Valley, 30 miles to the northeast, the thickness changes very little, but between Bass Canyon and Pipe Creek, 18 miles to the southeast, it decreases from 338 to 270 feet, and at Cottonwood Creek, southeast of Pipe Creek, it appears to be less than it is at Pipe Creek. Walcott's descriptions indicate that the member is much less sandy at Kanab Creek than at Nunkoweap Valley and somewhat less sandy at Kanab

20 Walcott, C. D., unpublished notes.
Creek than at Bass Canyon. It is therefore evident that the member as a whole becomes increasingly sandy southeastward from Kanab Creek.

Subdivisions A and B, which constitute the upper third of the Muav at Bass Canyon, are represented by equivalent strata in all the sections shown on Plates XIX and XX, except in the section at Cottonwood Creek, where they have been removed by erosion.

The relatively thick-bedded calcareous sandstone in the upper part of subdivision B of my Bass Canyon section is evidently equivalent to the gray and buff calciferous sandrock, 50 feet thick, which constitutes subdivision B of Walcott's section at Kanab Creek, and to the yellowish sandstone, 25 feet thick, which constitutes subdivision 2 of his section at Nunkoweap Valley. Probably subdivision B as defined by me includes a wider range of strata than the corresponding subdivision as defined by Walcott, and if so the thin-bedded sandstones of variable composition in the lower part of my subdivision B may be equivalent to beds of limestone at the top of Walcott's subdivision $\mathrm{C}$ at Kanab Creek and to beds of calcareo-arenaceous rocks at the top of his subdivision 3 at Nunkoweap Valley. Subdivision $\mathrm{B}$ as defined at Bass Canyon does not appear to undergo any significant lithologic change in the area between Garnet Canyon and Pipe Creek. The thick-bedded calcareous sandstone in the upper portion maintains a thickness of about 35 feet, whereas the subdivision as a whole varies irregularly in thickness, being 78 feet thick at Garnet Canyon, 72 feet at Bass Canyon, 95 feet at Slate Creek, 93 feet at Hermit Creek, and 87 feet at Pipe Creek. The fact that the boundary between subdivisions $\mathrm{B}$ and $\mathrm{C}$ is indefinite suggests that these variations may be only apparent, because in measuring some sections I may have included in subdivision B beds that are actually equivalent to beds in the underlying subdivision $\mathrm{C}$ of the Bass Canyon section.

Subdivision A as defined at Bass Canyon consists of massive buff crystalline limestone whose composition is approximately that of dolomite and which appears to be formed largely of calcareous or dolomitic sand. This subdivision is constant in lithologic character in all the sections between Garnet Canyon and Pipe Creek but exhibits many irregularities 
in thickness, owing to the fact that its upper surface is an unconformity of erosion. Its thickness is 70 feet at Garnet Canyon, 63 feet at Bass Canyon, 15 feet at Slate Creek, 29 feet at Hermit Creek, and 26 feet at Pipe Creek. In the region between Bass Canyon and Hermit Creek the beds of subdivision A have been entirely removed at many places and a large part of the underlying subdivision $\mathrm{B}$ has been removed at some places. These variations in thickness show the character and relief of the surface produced by erosion after the beds of subdivision A were deposited but afford no evidence concerning the original thickness of the beds.

Subdivision A is apparently equivalent to the massive mottled limestone, 60 feet thick, which constitutes subdivision 1 of Walcott's section at Nunkoweap Valley and to the massive arenaceous and more or less mottled limestone, 185 feet thick, which constitutes subdivision a of his section at Kanab Creek. At Kanab Creek, at Nunkoweap Valley, and in the area between Garnet Canyon and Pipe Creek these limestones lie at the top of the Muav. Everywhere, therefore, they occupy the same stratigraphic position with regard to the underlying beds of calcareous sandstone of subdivision B. Moreover, if it is assumed that the sand in Walcott's limestones is calcareous, they do not appear to differ conspicuously from the equivalent beds in the area between Garnet Canyon and Pipe Creek. Some of the beds in this intermediate area exhibit purplish blotches and mottlings, and all of them, like Walcott's beds, are massive. Inasmuch as the top of subdivision A is eroded at Kanab Creek and at Nunkoweap Valley as well as in the intermediate area it is impossible anywhere to determine the original thickness of the subdivision and consequently of the Muav limestone.

Frech's section ${ }^{21}$ at "Congress Canyon" (Red Canyon), 3 miles east of Cottonwood Creek, shows only 129 feet of strata at the summit of the Tonto group that can be confidently assigned to the Muav limestone. Probably he has included strata in the Redwall limestone which are actually equivalent to the Muav and Temple Butte limestones, because the thickness of 1,000 feet which he assigns to the Redwall at that locality is certainly too great by several hundred feet.
Fossils.-Fossils are scarce in the Muav limestone. At Kanab Creek, from the lower bed of mottled limestone in subdivision $\mathrm{c}$ of his section, Walcott ${ }^{22}$ obtained the following species:

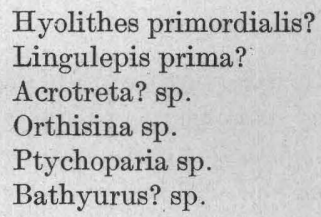

This bed of mottled limestone is probably roughly equivalent to my subdivision $\mathrm{D}$ of the Muav at Bass Canyon. (See pp. 43-44.)

From the upper bed of mottled limestone in subdivision $\mathrm{c}$ at Kanab Creek Walcott obtained the forms listed above and in addition a species of Lingula. This mottled limestone is probably equivalent to beds in the upper part of my subdivision $\mathrm{C}$ at Bass Canyon.

From beds in the upper part of the Muar limestone at Kanab Creek which are probably equivalent to my subdivision $\mathrm{A}$ at Bass Canyon Walcott obtained a species of Trematis and an imperfect specimen of Discina.

At Nunkoweap Valley the beds at the top of the Muar which are equivalent to my subdivision $\mathrm{A}$ at Bass Canyon are reported by Walcott to contain Lingulepis and Ptychoparia. (See columnar section at Nunkoweap Valley, Pl. XX.)

In the area covered by my sections between Garnet Canyon and Cottonwood Creek I have obtained fossils from the Muav limestone at only one locality. At Hermit ${ }^{\circ}$ Creek, from a bed of mottled limestone in subdivision C, 118 feet above the base of the subdivision, I collected

$$
\begin{aligned}
& \text { Finkelnburgia sp. } \\
& \text { Syntrophia sp. } \\
& \text { Anomocarella sp. } \\
& \text { Pagodia? sp. } \\
& \text { Ptychoparia? sp. }
\end{aligned}
$$

The locality is on the west slope of Cope Butte a few hundred feet north of the Hermit trail. The fossils were identified by Edwin Kirk, who states:

The fauna as shown in the collection might be either Middle or. Upper Cambrian. I think more extensive collections are needed definitely to prove its age. In this connection a faunal list given by Walcott ${ }^{23}$ might be of interest. This fauna is cited from the Tonto at Kanab Creek and is given as Upper Cambrian.

${ }^{22}$ Walcott, C. D., unpublished notes.

${ }^{23}$ Walcott, C. D., U. S. Geol. Survey Mon. 51, p.214, locality 75, 1912. 
At Hermit Creek, from a bed in subdivision C, 50 feet lower than that in which I found the fossils listed above, Schuchert ${ }^{24}$ obtained pygidia of Saukia and of Neolenus. In discussing the fossils collected at Hermit Creek he states, "These fossils, and more especially the trilobites, show that the Muav is of Upper Cambrian age."

Regarding the age of the Muav limestone Walcott ${ }^{25}$ states:

As far as can be determined from the present collections I should include the Muav limestone in the Upper Cambrian; the Bright Angel shale and Tapeats sandstone in the Middle Cambrian. However, it is very desirable that larger collections be made from the Muav limestone.

Therefore I have assigned the Muav limestone to the Upper Cambrian in the present report, although I realize that further collections of fossils are necessary before its age can be fixed definitely. A careful search for fossils at the top of the formation may yield interesting results, for if the Muav is in fact Upper Cambrian it is conceivable that strata younger than Cambrian and older than Upper Devonian may be preserved in some places beneath the surface of erosion at the top of the formation.

\section{UNCONFORMITY BETWEEN CAMBRIAN AND} DEVONIAN SYSTEMS.

Walcott has shown that both at Kanab Creek $^{26}$ and in the region about Nunkoweap Valley, ${ }^{27} 50$ miles southeast of Kanab Creek, the upper limit of the Tonto group is an unconformity. The unconformity at Kanab Creek he describes as a strong line of erosion that in places exhibits vertical irregularities of 80 feet within horizontal distances of a few hundred feet. In studying the Tonto group between Garnet Canyon and Cottonwood Creek I have traced this unconformity through a distance of about 28 miles in the south wall of the Grand Canyon in the Kaibab division. (See Pl. XX.) Probably, therefore, it extends continuously from Kanab Creek to Nunkoweap Valley. Further study may show that it extends far west of Kanab Creek.

Inasmuch as the unconformity lies within horizontal strata it can not be detected by

${ }^{24}$ Schuchert, Charles, op. cit., p. 369.

${ }^{25}$ Walcott, C. D., personal communication.

${ }^{26}$ Walcott, C. D., The Permian and other Paleozoic groups of the

Kanab Valley, Ariz.: Am. Jour. Sci., 3d ser., vol. 20, pp. 221-225, 1880.

${ }^{27}$ Walcott, C. D., Pre-Carboniferous strata in the Grand Canyon of the Colorado, Ariz.: Am. Jour. Sci., 3d ser., vol. 26, p. 438, 1883. discordance of dip and is plainly recognizable only where the eroded surface exhibits strong: relief. In places where the eroded surface: is level or nearly level, as, for example, at Bass Canyon and at Cottonwood Creek, the unconformity is obscure. Even where the surface is moderately irregular, as in the region about the Hermit and Bright Angel trails, the visitor may at first experience considerable difficulty in recognizing the unconformity until he knows exactly where to look for it.

At present the Hermit and Bright Angel trails afford the visitor the easiest opportunity to examine the unconformity. If he will deseend either of these trails to a point about a hundred feet below the base of the sheer cliff formed by the Redwall limestone, pick out the beds of massive cliff-making dolomite that constitute the topmost subdivision of the Muav limestone (see Pl. XX), and follow their upper surface, he will find broken-down areas in the top of the dolomite cliff, which at first sight may appear to be caused by masses of rock breaking off from the cliff but which close inspection will show to be hollows eroded in the dolomite and filled by overlying strata. As a rule the strata in the hollows exhibit pale purplish or pinkish tints, which contrast slightly with the prevailing buff or gray of the dolomite, although in many places their color is obscured by buff and gray stains washed over them from overlying beds. Moreover, they are softer than the dolomite and are irregularly bedded, so that they weather more easily than the dolomite and form slopes. Commonly, these slopes are wholly or partly covered with talus.

In the canyon of Garden Creek, through which the Bright Angel trail descends from the rim of the Grand Canyon at El Tovar, a hollow of the type just described is well exposed near the north end of the promontory that separates the canyon of Garden Creek from that of Pipe Creek. This hollow lies about half a mile east of Indian Garden and may be reached by leaving the trail near Indian Garden and climbing the long slope of Bright Angel shale and Muav limestone east of the Garden. Other hollows are exposed in the canyon of Garden Creek which the visitors will easily discover when he has learned where to look for them. The canyon of Pipe. 
Creek, east of Garden Creek, contains at least ten of them. Several are exposed in each of the canyons west of Garden Creek, between Garden Creek and Hermit Creek.

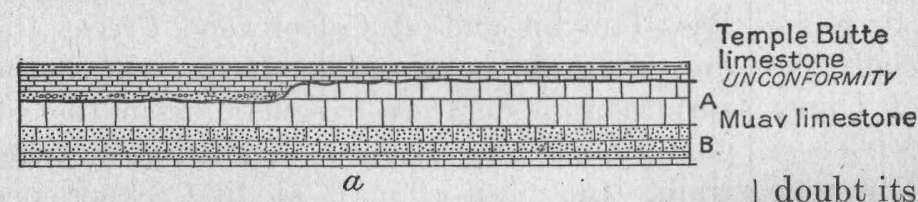

$a$
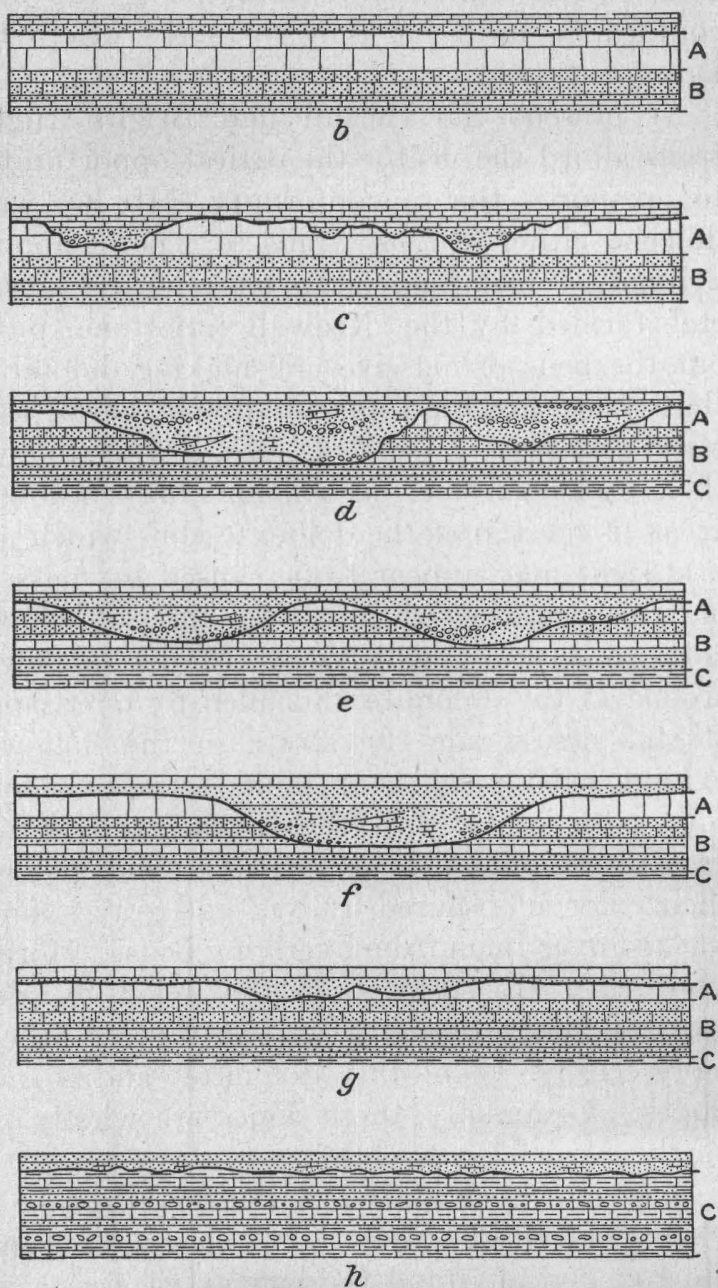

h

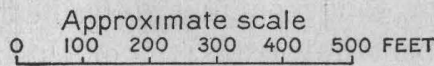

FIGURE 3.-Diagrammatic sketches showing general character of unconformity between Temple Butte limestone and Muav limestone at eight localities between Garnet Canyon and Cottonwood Creek, Grand Canyon, Ariz. $a$, Garnet Canyon; $b$, Bass Canyon; $c$, Ruby Canyon; $d$, Turquise Canyon; $e$, Slate Creek; $f$, Hermit Creek; $g$, Pipe Creek; $h$, Cottonwood Creek.

In the canyon of Hermit Creek a hollow nearly 80 feet deep lies in the northern slope of Cope Butte just east of and above the Hermit trail. To reach this hollow the visitor should leave the trail at the lower end of the tangent called "Long Drag" and climb eastward several hundred feet up the steep ledgy slope formed by subdivisions C and B of the Muar limestone, following a contact between bare rock on his left and talus on his right. The hollow is difficult to find, because all but the north end of it is concealed by talus, and the observer may The north end of the hollow affords good exposures of the gnarly, irregularly bedded pinkish or purplish calcareous sandrock that constitutes the typical deposit of known Devonian age in this part of the Grand Canyon (see p. 51), so that to one interested in the stratigraphy the hollow is well worth a visit because of its accessibility. A similar hollow is exposed on the west side of the canyon of Hermit Creek about a mile west of the hollow just described. It lies near the north end of the promontory that separates the canyon of Hermit Creek from the next large canyon west of it.

By far the best exposures of the unconformity which I have seen in the Grand Canyon are in the region between Hermit Creek and Bass Canyon, in the long straight canyons that head behind Diana, Pollux, and Castor temples, namely, Slate Creek, Agate, Sapphire, and Turquoise canyons; also in Ruby Canyon, $2 \frac{1}{2}$ miles southeast of Bass Canyon. In all these canyons the surface of erosion is irregular in many places, so that the unconformity is plainly evident at first sight, even when viewed from a considerable distance. This interesting region, however, is not easily accessible to the tourist.

The accompanying sketches of the unconformity (fig. 3) show the topographic character of the eroded surface at eight different localities between Garnet Canyon and Cottonwood Creek. The photographs reproduced in Plates XXII and XXIII, $A$, show details of the unconformity. At Garnet Canyon the surface is comparatively even and exhibits no narrow hollows. Depressions are eroded in it, but they appear to be so broad and flat that the general aspect of the surface is mesa-like. At Bass Canyon, 3 miles from Garnet Canyon, the surface is practically level, and I have observed only one irregularity in it in a distance of several thousand feet. This irregularity is a steplike drop of about 25 feet from one mesa-like level to another. At Ruby Canyon, $2 \frac{1}{2}$ miles from Bass Canyon, the surface is very uneven. The 


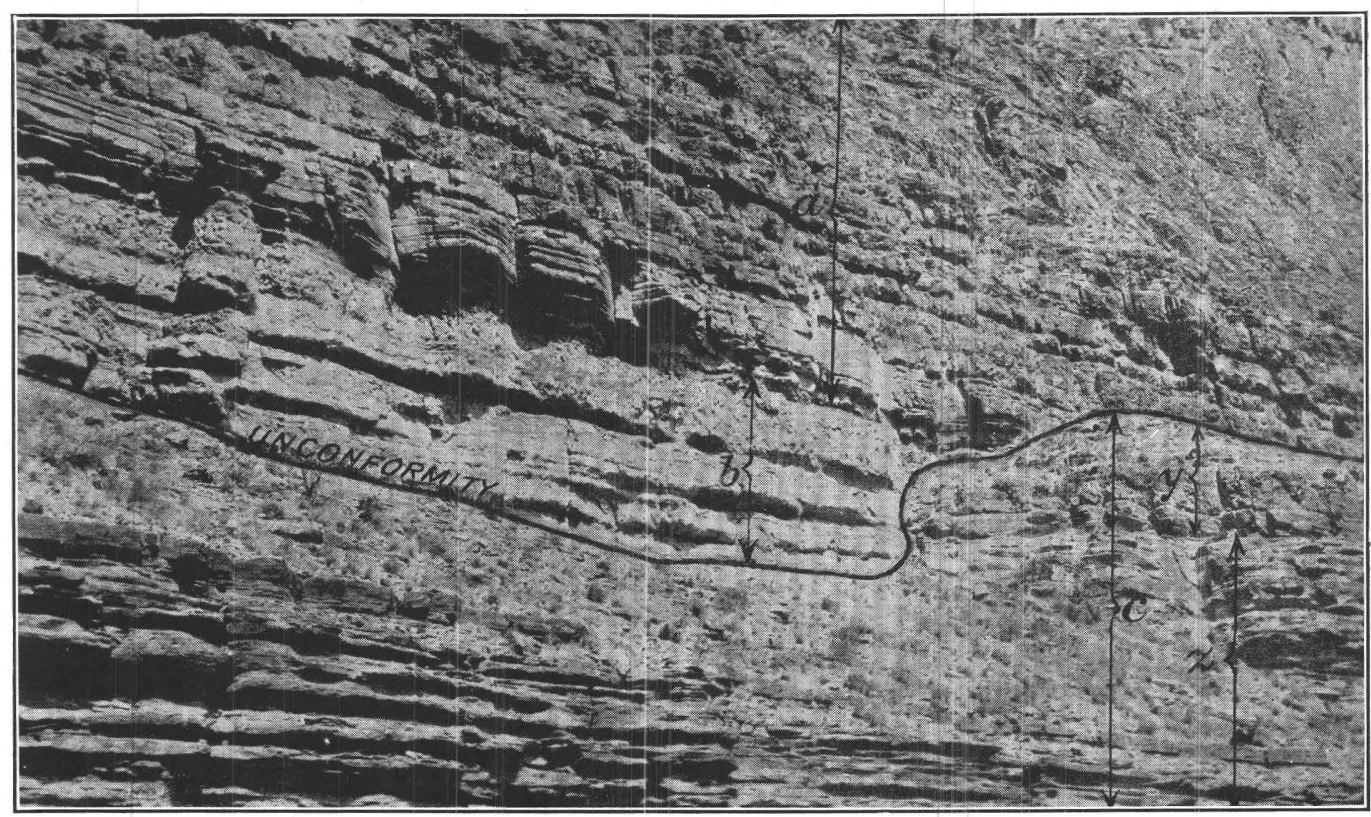

$A$.

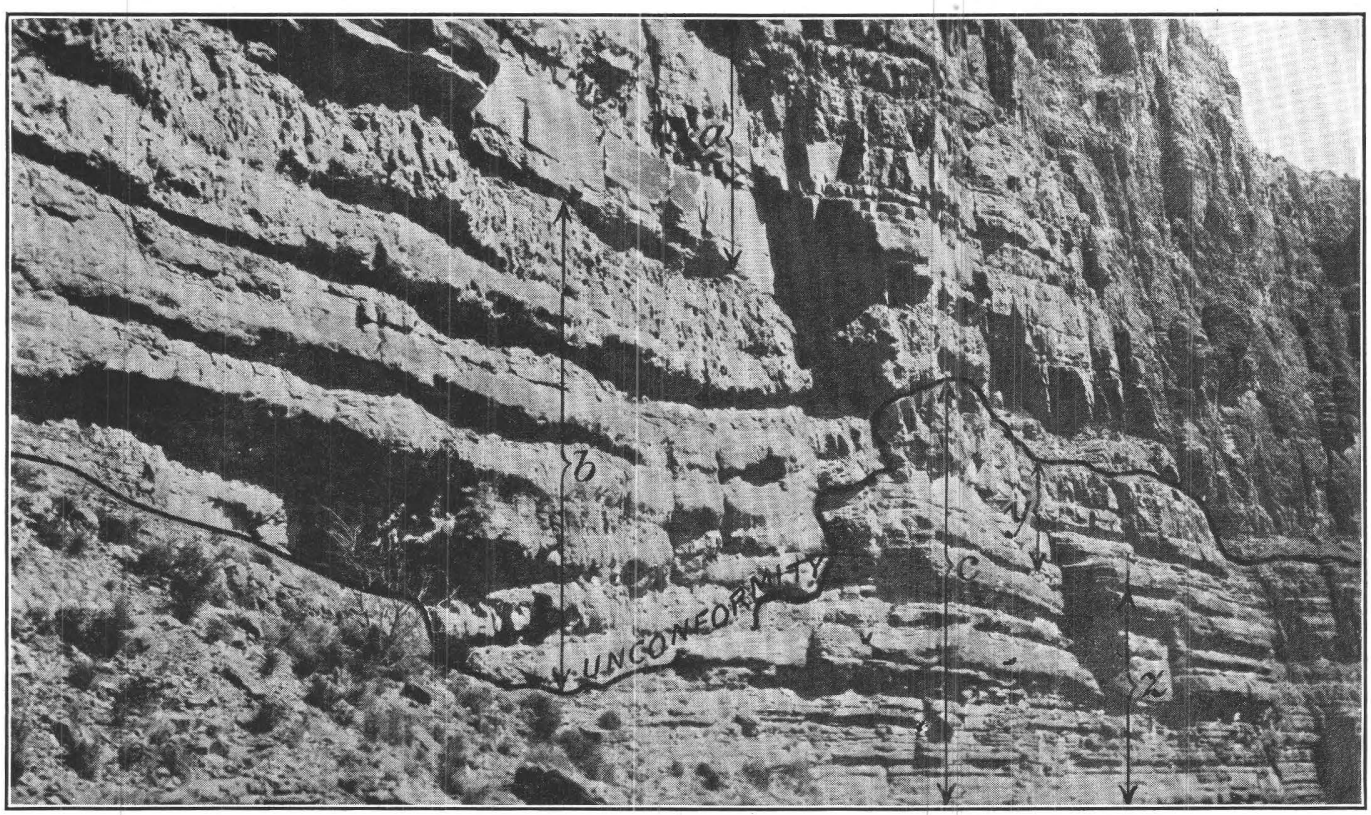

$B$.

UNCONFORMITY BETWEEN TEMPLE BUTTE LIMESTONE AND MUAV LIMESTONE IN WEST WALL OF CANYON OF SLATE CREEK, SHINUMO QUADRANGLE, ARIZ.

$a$, Redwall limestone; $b$, Temple Butte limestone; $c$, Muav limestone; $y$, $z$, subdivisions A, B of Muav limestone. The human figure just at the right of the sharp bend in the unconformity in $A$, gives an idea of the scale of the photograph. 


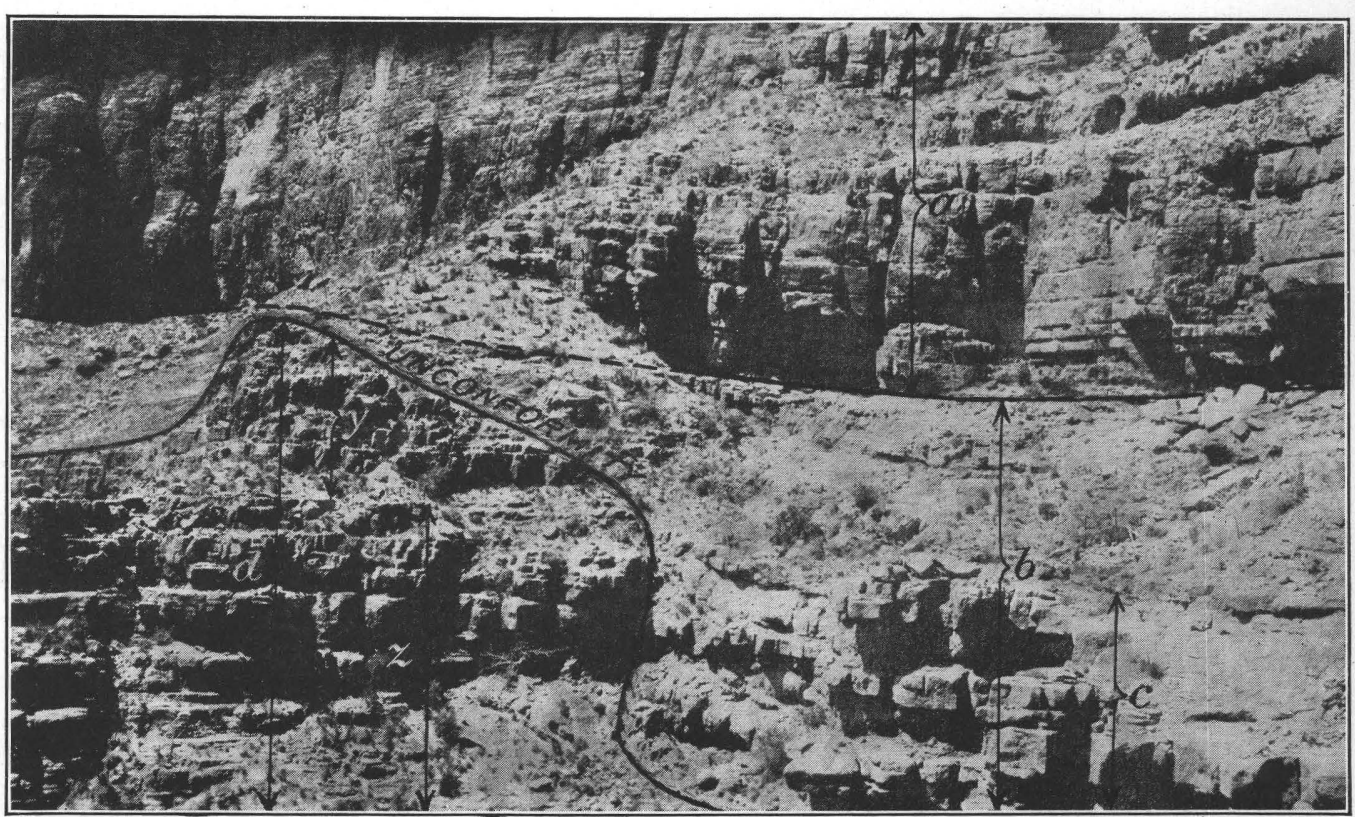

A. UNCONFORMITY BETWEEN TEMPLE BUTTE LIMESTONE AND MUAV LIMESTONE IN WEST WALL OF TURQUOISE CANYON, SHINUMO QUADRANGLE, ARIZ.

$a$, Redwall limestone; $b$, Temple Butte limestone; $c$, conglomerate; $d$, Muav limestone; $y, z$, subdivisions A, B of Muav limestone.

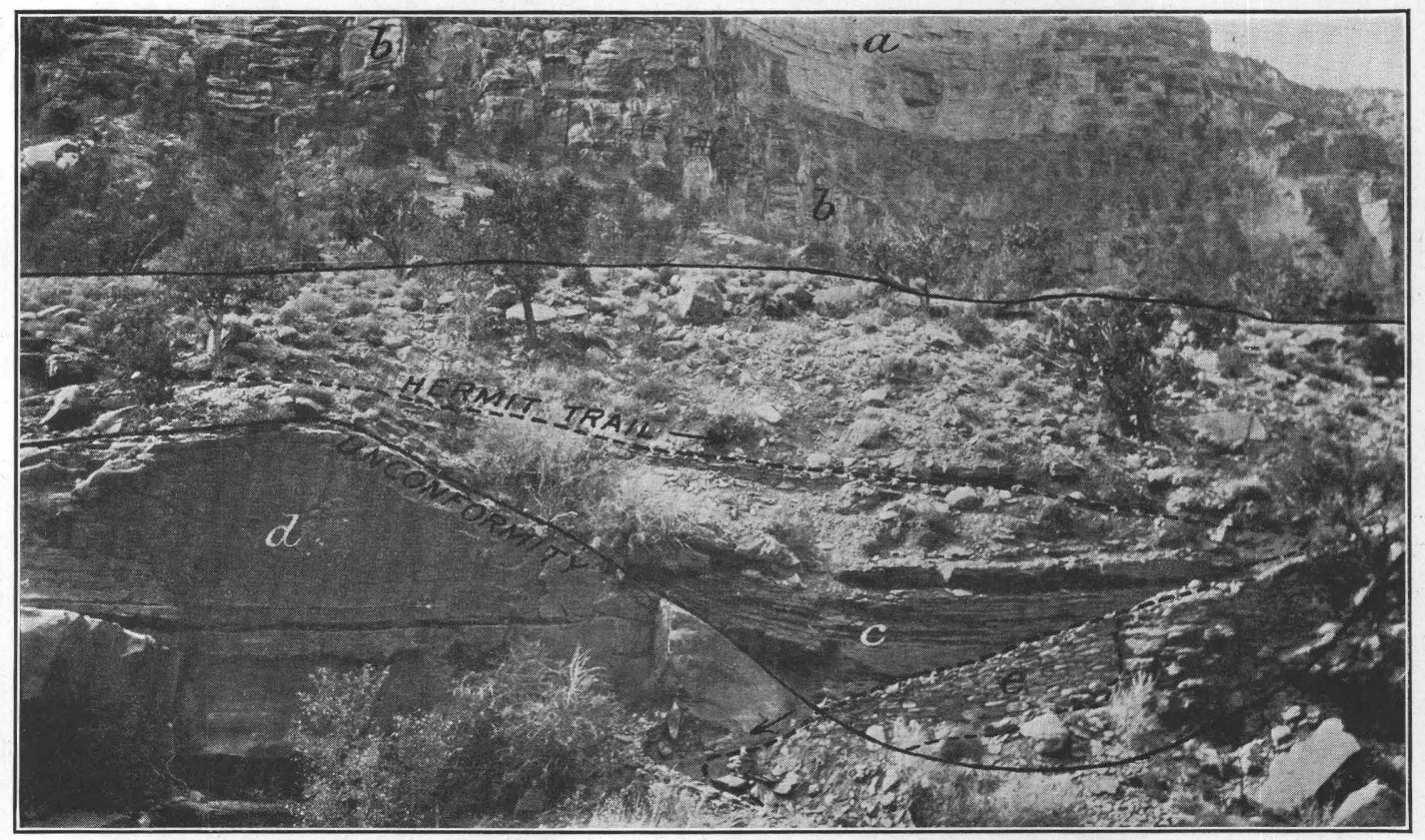

B. UNCONFORMITY BETWEEN HERMIT SHALE AND SUPAI FORMATION AT RED TOP, ON HERMIT TRAIL, BRIGHT ANGEL QUADRANGLE, ARIZ.

$a$, Kaibab limestone; $b$, Coconino sandstone; $c$, Hermit shale; $d$, Supai formation; $e$, artificial fill below trail. 
depressions in it are numerous, irregular in profile, and comparatively narrow. Some of these hollows are 40 feet deep. At Turquoise Canyon, $2 \frac{1}{2}$ miles from Ruby Canyon, the hollows are less numerous but are broader and deeper than they are at Ruby Canyon. Some are 80 feet deep. In profile they are irregular, like those at Ruby Canyon. At Slate Creek, 3 miles from Turquoise Canyon, the hollows are broad and deep but are more symmetrical in profile than those at Ruby Canyon. At Hermit Creek, 5 miles from Slate Creek, they are symmetrical, broad, and deep but are much less numerous than at Slate Creek. At Pipe Creek, $5 \frac{1}{2}$ miles from Hermit Creek, they are shallower and narrower than at Hermit Creek but otherwise resemble those at Hermit Creek. Southeast of Pipe Creek they disappear, and at Cottonwood Creek, 7 miles from Pipe Creek, the unconformity is rèpresented by a slightly wary surface which does not appear to exhibit vertical irregularities of more than 3 or 4 feet in horizontal distances of hundreds of feet.

In the region between Ruby Canyon and Pipe Creek the hollows look like cross sections of ancient stream valleys. If they are, I believe it would be possible by studying and mapping the hollows between Slate Creek and Ruby Canyon to identify certain ancient valleys in opposite walls of a canyon, trace them through the narrow promontories separating the canyons, and thus by restoring in imagination their courses over a considerable area determine their direction and grade.

\section{DEVONIAN SYSTEM.}

TEMPLE BUTTE LIMESTONE.

Although the upper limit of the Tonto group is clearly defined by the unconformity just described, the correlation of the beds that lie between this unconformity and the sheer cliff of the Redwall limestone is a difficult problem. The beds differ from place to place in thickness, character, and succession and are not separated from the overlying Redwall strata, of known Mississippian age, by a sharp stratigraphic break like the unconformity at the summit of the Tonto. Some beds are unquestionably of Devonian age, and others may be Mississippian, but owing to their variation in character and succession and to the absence of sharp stratigraphic breaks their separation can be established definitely only by the aid of fossils.
Many beds contain obscure traces of life, but determinable forms are scarce and the beds are difficult to reach in many places where it seems desirable to study them. It will be necessary to make a more thorough study of the beds than I have yet attempted, and particularly to make a systematic search for fossils in them, before their age and corrélation can be established in detail. Meanwhile the correlations presented in this report (see Pl. XX) should be regarded as tentative.

Fortunately one type of deposit that can be recognized wherever it is present by its peculiar lithologic character has yielded fossils at one locality which conclusively establish its age as Devonian. This deposit is an irregularly bedded, gnarly pinkish or purplish calcareous sandrock which fills hollows in the surface marked by the unconformity. It is exposed most typically in the canyons between Ruby Canyon and Pipe Creek (see fig. 3 and Pl. XX) and is apparently represented by equivalent beds at Garnet Canyon and at Cottonwood Creek. It is not exposed at Bass Canyon. Apparently it is the oldest deposit laid down upon the post-Tonto surface in this part of the Grand Canyon.

The locality where I found fossils in the deposit is in Sapphire Canyon, at an elevation of about 3,700 feet, in the main stream course of the canyon. At this point the deposit fills a depression about 50 feet deep eroded in the Muav limestone. It consists essentially of irregularly bedded calcareous sandrock whose component grains are chiefly calcareous or dolomitic sand; the rock might thus be classed either as limestone or as sandstone. Some beds, however, are compact crystalline limestone or dolomite, and some are coarse conglomerate. A few beds consist of bright-red finegrained friable sandstone or sandy shale which resembles the Hermit shale higher in the canyon wall. (See p.64.) In places this red sandstone shows concretionary structure, and some beds exhibit sun cracks. Practically all the calcareous sandrocks and associated beds are in lenticular layers which are highly irregular and are of no great horizontal extent, commonly wedging out within distances of less than 100 feet. Local unconformities are common between the beds. No two vertical sections of the deposit are alike, even in the same hollow. The prevailing color of the beds is 
pinkish or purplish gray, but some beds display green or yellowish tints, and some are white or cream-colored. In many places the colors are mingled in blotches and streaks. Most of the rock is moderately fine grained, and nearly all of it exhibits cross-bedded structure. In many parts of the deposit, but particularly at the top, the bedding is curiously gnarled and contorted. Probably this gnarly structure is an irregular form of cross-bedding.

The fossils occur in the lower part of the deposit, most of them within 3 feet of the base. They are abundant but are fragmentary and poorly preserved. A few fragments are scattered through higher beds. The following analysis of a representative sample of the rock in which the fossils occur shows that the rock is an impure dolomite.

Partial chemical analysis of limestone from Sapphire Canyon.

[Alfred A. Chambers, analyst.]

Insoluble....................... 10.96

$(\mathrm{Al}, \mathrm{Fe})_{2} \mathrm{O}_{3} \ldots \ldots \ldots \ldots \ldots \ldots \ldots \ldots \ldots \ldots \ldots$

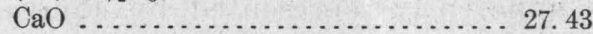

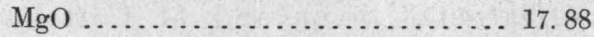

The fossils are scales and plates of fishes. The material which I collected was examined by J. W. Gidley, who writes:

I have gone over your collection critically and find only Bothriolepis represented in the lot. The material is too fragmentary to be determined specifically. However, the form represented appears to agree rather more closely with an Eastern species, B. nitidus, found in the Catskill formation, than it does with the common western form. B. canadensis. This, however, is not important for your purpose, except that it certainly indicates Upper Devonian.

So far as I know, Bothriolepis is characteristic of the Upper Devonian and is not known to occur below the Middle Devonian.

In addition I may state that in the character of the rock and broken condition of the fish remains your collection is very similar to the Catskill material.

The deposits of the type just described can therefore be assigned without question to the Devonian Temple Butte limestone, which, according to Walcott, ${ }^{28}$ "is unmistakably marked by thin purplish-colored layers of fine-grained sandstone that pass into calcareous sandrock and limestone in which cyathophylloid corals, casts of brachiopods and gastropods, and plates of placoganoid fishes usually occur." Fossils will probably be found in other localities than the one in Sapphire Canyon when systematic search is made for them.

28 Walcott, C. D., Pre-Carboniferous strata in the Grand Cany on of the Colorado, Ariz.: Am. Jour. Sci., 3d ser., vol. 26, p. 438, 1883.
The deposits just described are essentially similar wherever they are exposed, although they may differ somewhat in lithologic detail. At Turquoise Canyon, for example, they contain many lenses of conglomerate, whereas at many other localities they may contain little or none. At some places they may contain no bright-red sandstone or shale, and at some places little or no limestone or dolomite. Calcareous sandrock characterized by gnarly or contorted bedding, however, is always present. At Turquoise and Sapphire canyons and at the canyons of Slate and Hermit creeks the upper part of the deposits consists wholly of gnarly sandrock, which forms a massive, rather distinct bed from 20 to 25 feet thick. Commonly the upper part of this bed extends over the top of the higher Cambrian knolls to a depth of 5 to 15 feet.

At Bass Canyon the massive dolomite (subdivision A) at the top of the Muav limestone is overlain by 75 feet of thin-bedded purplish to white sandy limestone which is mottled in places by worm markings and contains a few beds of intraformational conglomerate similar to that in the Muav limestone. This thinbedded limestone contains no determinable fossils, although one bed contains obscure forms that are probably cup corals. A detailed section of the limestone is given on pages 32-33. The following analysis shows the composition of a sample of the limestone taken from bed 14 , at the base of the section:

Partial chemical analysis of limestone from bed 14, Temple Butte limestone.

[Alfred A. Chambers, analyst.]

Insoluble..................... 24.41

$(\mathrm{Al}, \mathrm{Fe})_{2} \mathrm{O}_{3} \ldots \ldots \ldots \ldots \ldots \ldots \ldots \ldots . . .6 . .63$

$\mathrm{CaO} \ldots \ldots \ldots \ldots \ldots \ldots \ldots \ldots . . .22 .95$

$\mathrm{MgO} \ldots \ldots \ldots \ldots \ldots \ldots \ldots \ldots \ldots . . .15 .01$

The rock is therefore an impure magnesian limestone or dolomite. The insoluble impurities are probably largely quartzose sand.

The beds of sandy limestone are overlain by a massive bed of brecciated limestone (see p. 32 ), which lies at the base of the Redwall cliff. Both upper and lower surfaces of this brecciated limestone are wavy, but I am not sure that they represent planes of erosion. At any rate the brecciated bed marks an abrupt change in lithology, and I have placed it at the base of the Mississippian Redwall. 
At most places in Bass Canyon the contact between the thin-bedded sandy limestone and the underlying massive dolomite of the Muav limestone is an even line, so that the two formations appear to be conformable. But at Garnet Canyon, 3 miles west of Bass Canyon, and at Ruby Canyon, 2 miles southeast of Bass Canyon, the thin-bedded sandy limestone is separated from the Muar by a plain line of erosion. (See fig. 3.) The contact is therefore an unconformity.

I have assigned the 75 feet of thin-bedded sandy limestone exposed at Bass Canyon to the Devonian Temple Butte limestone, because at Garnet Canyon (see Pl. XX) similar beds overlie a gnarly purplish conglomeratic sandrock that resembles the deposit in which fish remains occur in Sapphire Canyon and are overlain by other beds of gnarly conglomeratic sandrock and red shale, so that at Garnet Canyon the thin-bedded sandy limestone is actually included within beds that are lithologically identical with the known Temple Butte limestone.

\section{POSSIBLE UNCONFORMITY BETWEEN DEVONIAN AND CARBONIFEROUS SYSTEMS.}

Walcott ${ }^{29}$ has shown that at Kanab Creek the Redwall limestone is separated from underlying Devonian beds by a line of erosion, but I am unable confidently to trace this unconformity in the region between Garnet Canyon and Cottonwood Creek and at all places to separate Devonian beds from the Redwall limestone.

At Hermit Creek the sequence of beds between the Devonian Temple Butte limestone and the Redwall strata of known Mississippian age is as follows:

Section in western slope of Cope Butte, near Hermit trail.

[For profiles of section see Pls. XIX and XX.]

Massive gray magnesian limestone of known Mississippian age forming lower part of sheer Redwall cliff.

1. Alternating beds of gray magnesian limestone, buff sandstone, and chert; partly concealed; form slope....................... 15

2. Massive gray vesicular crystalline magnesian limestone; cavities contain coarse crystals of of calcite; forms cliff.................. 11

3. Concealed beds; form slope.............. 6

4. Limestone like bed 2 ; cliff............... 7

29 Walcott, C. D., The Permian and other Paleozoic groups of the Kanab Valley, Ariz.: Am. Jour. Sci., 3d ser., vol. 20, pp. 221-225, 1880.
5. Band of chert layers; weathering black.......

6. Limestone like bed 2 ; cliff.................

7. Buff sandstone with bands of chert...........

8. Limestone like bed 2 ; cliff................

9. Buff sandstone with bands of chert...........

10. Limestone like bed 2 but sandy; slope........

11. Sandy conglomerate composed largely of fragments of calcareous sandrock; cliff; base of bed uneven, wavy .....................

Gnarly purplish and white calcareous sandrock of known Devonian age (Temple Butte limestone) lying in hollow eroded in Muav lime. stone; upper surface of sandrock uneven, wavy; in places exhibits inequalities of 3 feet

Feet. 7 5 7 2

4

The following analysis of a representative sample of the limestone forming bed 8 of the foregoing section probably shows approximately the composition of beds 2,4 , and 6 as well, because none of these beds differ in appearance.

Partial chemical analysis of limestone from bed 8, Cope Butte. [Alfred A. Chambers, analyst.]

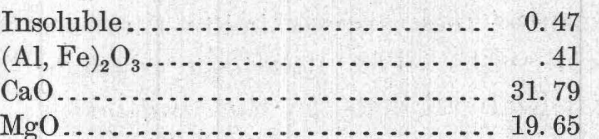

The limestone is therefore a practically pure dolomite, and it is interesting to note that the chemical composition of this rock is almost exactly that of the overlying limestone, which forms the lower part of the Redwall cliff (see analysis, p. 55) and from which, indeed, the limestone of bed 8 is almost indistinguishable in appearance, differing only in the thickness of the bedding.

Because the limestones in the series of beds 1 to 11 of the above section are lithologically identical with the beds at the base of the overlying Redwall limestone I have assigned the series to the Redwall limestone. The lithologic change from these beds to the gnarly sandrock underlying them is sharp, and it is possible that the wavy line at their base marks an erosional unconformity which separates the Devonian from the Mississippian. However, I do not wish unduly to emphasize the importance of the latter feature, because wavy surfaces occur at many horizons in the Redwall and Temple Butte limestones and are not necessarily of widespread stratigraphic significance.

Massive beds of gray vesicular magnesian limestone that alternate with layers of sand or 
chert and are similar to the series at Hermit Creek just described are exposed at Turquoise Canyon and in the canyons of Slate, Pipe, and Cottonwood creeks, where I have also assigned them to the Redwall limestone. (See Pl. XX.) Apparently the series thickens southeastward and attains a thickness of more than 100 feet in the region about Cottonwood Creek, but I have examined it in detail only at Hermit Creek. At Turquoise Canyon and Slate Creek it is underlain by 15 to 20 feet of thin-bedded sandy purplish and whitish magnesian limestones; those at Slate Creek I have assigned tentatively to the Temple Butte limestone (see Pl. XX), because they resemble the thinbedded Temple Butte limestone at Bass Canyon (see pp. 51-53), although it is possible that they belong at the base of the Redwall limestone, for they are separated from underlying gnarly'sandrock of Devonian age by a slightly wavy surface. At Bass Canyon no beds at all resembling the massive vesicular limestones of Hermit Creek appear below the base of the Redwall cliff. The lithologic change from typical Redwall beds to the thin-bedded purplish sandy limestone of the Devonian takes place at a brecciated bed at the very base of the cliff, and the plane of separation, as stated on page 53 , may or may not be an unconformity. At Garnet Canyon all beds above the known Devonian are inaccessible. An uneven surface is exposed there at the top of the highest beds that I could reach, but I do not know whether this surface is an unconformity separating Devonian and Mississippian or only a local unconformity in the Temple Butte limestone.

In brief, if an unconformity separates the Temple Butte limestone and the Redwall limestone in the region which I have examined, it is so obscure and exhibits so little irregularity that it can be detected only by obtaining determinable fossils in the strata within which it lies. Certainly no surface of erosion exists which is at all comparable in irregularity with that which separates the Tonto group from overlying beds.

\section{CARBONIFEROUS SYSTEM.}

MISSISSIPPIAN SERIES.

REDWALL LIMESTONE (RESTRICTED).

Definition.-In previous publications the Redwall limestone has been classified as of Pennsylvanian and Mississippian age. As orig- inally defined by Gilbert ${ }^{30}$ the formation was "named from the red appearance of its escarpments on either side of the Grand Canyon" and included in its top 200 to 510 feet of alternating sandstones and limestones of "Coal Measures" (Pennsylvanian) age. Later writers have also included these Pennsylvanian beds in the Redwall, although Darton ${ }^{31}$ in 1910 expressed the belief that they properly belonged to the overlying Supai formation. In the present report these beds of Pennsylvanian age are transferred to the Supai formation, to which, by reason of their lithology, age, and probable unconformable contact with the Mississippian rocks, they seem more properly to belong. The name Redwall limestone is therefore here restricted to the massive gray crystalline limestones of Mississippian age, and this restricted definition has been adopted by the United States Geological Survey.

Character.-The Redwall limestone as here restricted consists almost wholly of bluish-gray crystalline limestone whose distinctive features are massive appearance, hardness, and relatively great thickness. The massive appearance of the limestone is due partly to the thickness and homogeneity of the beds but chiefly to the fact that the planes of separation between many beds are inconspicuous, so that when viewed from a distance large parts of the formation present the appearance of a single stratum. The hardness and thickness of the limestone cause it to make the sheerest and most continuous cliff in the canyon wall.

At Bass Canyon the Redwall limestone is about 570 feet thick and is divisible into three parts which differ in topographic expression. Subdivision C, at the base of the formation, makes a slope that unites with the steep ledgy slope formed by the Temple Butte limestone (see p. 32) and is a bed of sandy breccia 8 feet thick whose fragments consist chiefly of gray limestone. It is overlain by bluish-gray massive crystalline limestone, obscurely bedded at the base and top, which makes a cliff approximately 500 feet high. This cliff-making limestone constitutes subdivision B. Subdivision A, at the top of the formation, consists of distinctly bedded bluish-gray crystalline limestone which includes a few thin partings of red

${ }^{30}$ Gilbert, G. K., U. S. Geog. and Geol. Surveys W. 100th Mer. Rept., vol. 3 , pp. $161,162,177,178$, 185 , fig. 82,1875 .

31 Darton, N. H., A reconnaissance of parts of northwestern New Mexico and northern Arizona: U. S. Geol. Survey Bull. 435, p. 22, 1910. 
shale. This subdivision, 62 feet thick, makes a succession of small cliffs and narrow ledges above the sheer cliff formed by subdivision B. The character and succession of the Redwall beds are described in the sections given on pages 31-32, and the profiles of the subdivisions are shown in the columnar section (Pl. XIX).

Subdivisions $\mathrm{A}$ and $\mathrm{C}$ can not be traced with certainty far from Bass Canyon, but subdivision $\mathrm{B}$, the main cliff-making portion of the Redwall, is constant in lithology and in appearance and is readily recognizable everywhere in the Kaibab division of the Grand Canyon. The upper and lower portions of the subdivision are obscurely and heavily bedded, whereas the middle portion is distinctly bedded and contains many thin layers of chert and sand. Most beds in the subdivision contain a few scattered nodules of chert, but chert is conspicuously abundant only in the middle, distinctly bedded portion. Many beds contain coarse crystals of calcite, some of which line cavities, some of which form large irregular masses in the rock, and some of which form layers a few inches to a foot thick. Interbedded layers of sandstone occur throughout the subdivision but are numerous only in the middle portion. As a rule the sand is loosely cemented and exhibits gnarly structure. Many beds rest on irregular, wavy surfaces. In many places the limestone cliff is stained pinkish or pale rose color by ferritic pigment washed over it from overlying red shales in the Supai formation. Unstained surfaces of the limestone commonly weather gray or bluish gray. Freshly broken surfaces are gray, buff, or white.

The following analyses show the composition of representative samples of limestone from subdivision $B$ at Bass Canyon. No. 1 represents the obscurely bedded limestone (No. 1, p. 32) that forms the upper part of the subdivision; No. 2, the heavily bedded limestone (No. 3, p. 32) that forms the lower part.

Partial chemical analyses of limestone from subdivision $B$, Redwall limestone.

[Alfred A. Chambers, analyst.

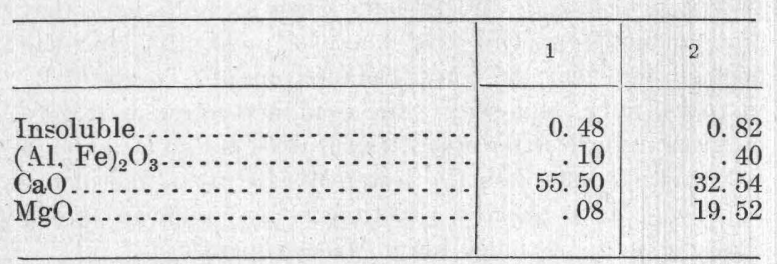

These analyses show that the limestone at the top of the subdivision is practically pure, whereas that at the base is magnesian and is essentially dolomite. The composition of the limestone forming the middle, laminated member of the subdivision was not determined by analysis, but inasmuch as this limestone resembles that in the overlying obscurely bedded member in appearance and effervesces freely with acid, it is probably not magnesian. The limestones in subdivision A resemble those in the upper part of subdivision B and effervesce freely with acid. It would appear, therefore, that the limestone in the whole upper portion of the Redwall is comparatively pure and only that in the basal member of subdivision B is magnesian.

Southeastward from Bass Canyon subdivision B diminishes gradually but steadily in thickness. At Bass Canyon it is approximately 500 feet thick; at Hermit Creek, 13 miles southeast of Bass Canyon, 475 feet; and at Red Canyon, 16 miles farther southeast, 375 feet. Red Canyon is 4 miles east of Cottonwood Creek. This decrease in the thickness of subdivision B is readily apparent to most observers in the diminished height of the Redwall cliff when seen from Grandview or Desert View, as contrasted with the height of the cliff when seen from the head of the Hermit trail or from Bass Camp.

Subdivision A as defined at Bass Canyon is traceable southeastward at least as far as Hermit Creek (see columnar sections, Pl. XIX), but subdivision $\mathrm{C}$ is not traceable southeast of Ruby Canyon, 2 miles from Bass Canyon. At Slate Creek, 8 miles southeast of Bass Canyon, and in the region southeast of Slate Creek (see $\mathrm{Pl}$. XX) subdivision $\mathrm{B}$ is underlain by a series of gray vesicular magnesian limestones and interbedded sandstones which make a steep ledgy slope beneath the cliff of subdivision B. A section of these alternating limestones and sandstones at Hermit Creek is given on page 53. This series, which I have assigned to the Redwall limestone (see p. 53), apparently occupies a lower horizon in the Redwall than subdivision $\mathrm{C}$, which actually is probably a local bed at the base of subdivision B. The alternating limestones and sandstones thicken southeastward, for they are 68 feet thick at Hermit Creek and at least 130 feet (estimated) at Red Canyon. I have not measured them at Slate, Pipe, and Cottonwood creeks. 
Thickness.-The Redwall limestone decreases in thickness in the 29 miles between Bass Canyon and Red Canyon. It is 570 feet thick at Bass Canyon, 538 feet at Hermit Creek, and a little over 500 feet at Red Canyon. The decrease in thickness in the formation as a whole is not so great as the decrease in its cliff, because the series of alternating limestones and sandstones at the base of the formation increases in thickness southeastward as the overlying cliff-making limestone diminishes. At Kanab Creek, 30 miles northwest of Bass Canyon, the formation is a little over 700 feet thick. (See Pl. XIX.)

Fossits.-Fossils are scarce in the Redwall limestone at the Bass, Hermit, and Bright Angel trails. Commonly they are poorly preserved and are difficult to collect unless they are weathered out of the rock. In 1914 I made small collections at two localities. At Bass Canyon I obtained from the middle, distinctly bedded member (2) of subdivision B Fenestella sp. and Schuchertella chemungensis. This locality is at the Bass trail near the bottom of the narrow part of Bass Canyon in the Redwall.

In the canyon of Hermit Creek I obtained from the same middle member of subdivision B

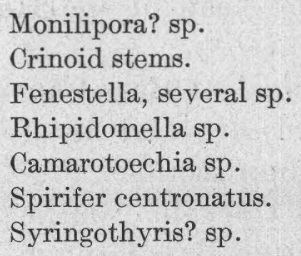

The fossils were identified by G. H. Girty, who writes:

Although these fossils are poor and constitute a very small fauna, they indicate with but little uncertainty a Mississippian (Madison) age and thus confirm previous determinations of the age of the lower and major part of the Redwall limestone. It is true that an undoubted Pennsylvanian fauna has been cited by Meek from the upper part of the Redwall limestone of this general region, but these fossils came from beds that are now being transferred to the Supai formation.

In 1920 I collected fossils from beds near the top of the Redwall limestone at two localities.

One collection, which I labeled lot C, I obtained at the very top of the Redwall cliff in the eanyon of Garden Creek directly under El Tovar. The locality is about an eighth of a mile east of the point where the Bright Angel (Cameron) trail descends the Redwall cliff and may be reached by leaving the trail at this point and walking eastward along the narrow bench at the summit of the cliff. The fossils weather from the upper surface of the limestone that underlies this bench, and the horizon appears to be equivalent to the very top of subdivision B of the Bass Canyon section.

The other collection, which I labeled lot A, I obtained from bed 5 of subdivision $\mathrm{A}$ in Bass Canyon. (See p. 31.) The locality is on the west side of Bass Canyon about a quarter of a mile north of the point where the Bass trail descends the break in the Redwall cliff at the head of the canyon. It may be reached by following the first bench above the top of the sheer cliff of subdivision B that is wide enough for a man to walk upon. The fossiliferous horizon is about 14 feet above the top of the cliff.

Regarding these two collections Mr. Girty writes:

Lot $\mathrm{C}$ contains an abundant fauna, though one showing but little diversity and represented by very unsatisfactory specimens. I recognize in it the following forms:

Diphyphyllum? sp. (probably the same form shown by better specimen in lot $\mathrm{A}$ ):

Camarotoechia? n. sp.

Spirifer centronatus.

Spirifer aff. S. incertus.

Composita? sp.

Bellerophon sp.

Euomphalus? sp.

Lot A contains Diphyphyllum (Lithostrotion?) sp., Camarotoechia? (apparently the same form as in lot $\mathrm{C}$ ), and a fucoid.

These two lots contain essentially the same fauna and are of the same geologic age. As between Pennsylvanian and Mississippian, I should refer them with little question to the Mississippian. As between lower Mississippian and upper Mississippian-that is, as between Madison and Brazer-a definite conclusion can not be reached. So few occurrences of upper Mississippian rocks are known in this southwestern region that a general probability is established that these faunas belong to the lower horizon. The facies of the faunas corresponds so far as it goes with the lower Mississippian faunas, as we know them now, but the forms contained in these collections are so few, so poorly represented, and in some cases so ambiguous that one can not deny the existence of a possibility that the geologic age may be upper Mississippian. To state the matter briefly, as I see it, the evidence so far as it goes suggests lower Mississippian, but it does not go far enough definitely to establish the lower Mississippian age of the horizon. My personal convictions, I may add, are strong that the age is actually lower Mississippian. 
Schuchert, who has collected fossils in the Redwall at the Hermit trail, states: ${ }^{32}$

The base of the Redwall on the Hermit trail consists of three thick beds. The upper one is from 10 to 12 feet thick, and the lowest bed is 8 feet thick, of a vesicular gray dolomite with the cavities filled with calcite. The upper bed has Syringopora cf. surcularia. Between these two dolomite beds is a yellowish-white sandstone, 4 feet thick. $^{33}$

The Redwall may be studied on the Hermit trail below the Cathedral Stairs, but the sequence can not be made out with certainty because all of it has slumped and slid down in a huge landslide. The parts are mixed, and even some of the Supai is included with blocks of the Redwall. One entire day was devoted to collecting fossils from it, but the results were very unsatisfactory. Toward the middle of the Redwall were seen sections of a few corals, of Menophyllum and Clisiophyllum, and a number of crinoidal columnals, besides Spirifer centronatus. Of the few fossils taken away there is a Syringopora like $S$. surcularia Girty, Menophyllum excavatum Girty, Fenestella and Polypora in several species, and a finely striate Spirifer.

These fossils are seen to belong to the same fauna as those identified by Girty from near Nelson, Ariz., and collected by W. T. Lee. The time indicated by them is that of the Madison limestone so widely distributed in the Rocky Mountain country, or of the older half of the Mississippian of the Mississippi Valley.

In 1879 Walcott collected fossils at Kanab Creek at many horizons in beds which he designated subdivisions $\mathrm{b}$ and $\mathrm{c}$ of the Redwall limestone. (See PI. XIX.) These two subdivisions and the underlying subdivision $\mathrm{d}$ of Walcott's section correspond closely in lithology with the Redwall of my Bass Canyon section and constitute the Redwall as it is here redefined. Subdivision a, at the top of Walcott's Redwall at Kanab Creek, corresponds in lithology to my subdivision C of the Supai formation at Bass Canyon and undoubtedly properly belongs in the Supai. (See p. 62.)

These collections from subdivisions $\mathrm{b}$ and $\mathrm{c}$ at Kanab Creek were never worked up in detail by Walcott and in the course of time have become badly mixed with collections made from other Carboniferous beds in the general region. However, Mr. Girty, who has examined the material, makes the following statement concerning as much of it as he is able to assign to the collections from $b$ and $c$ :

The faunas are much more extensive and conclusive than the one contained in your lots $\mathrm{A}$ and $\mathrm{C}$, and I refer them without hesitation to the lower Mississippian, to that widespread limestone formation which has commonly been

?2 Schuchert, Charles, op, cit., pp. 360-361.

${ }_{35}$ The three dolomite beds described by Schuchert are probably beds

2,4 to 6 , and 8 of my section at Cope Butte given on page 53.-L. F. N. called the Madison limestone but which in New Mexico has received the name Lake Valley limestone. I do not myself feel in doubt, although the evidence is not entirely conclusive, that the entire Redwall limestone, so far as it is embraced within the horizons represented by your collections A and C and by Mr. Walcott's collections from Kanab Canyon, is of lower Mississippian age and belongs in a general alinement with the Madison limestone.

The type locality of the Redwall limestone selected by Darton ${ }^{34}$ is Redwall Canyon, in the Shinumo Amphitheater, only 4 miles north of Bass Canyon. The section at Bass Canyon, given in the present report, is so near Redwall Canyon that it may be assumed practically to represent the formation at the type locality. The evidence just presented indicates that at the type locality the entire Redwall as here restricted is of lower Mississippian age, although it is conceivable, but highly improbable, as Girty states, that the beds at the top of the formation in which I found fossils may be upper Mississippian.

No evidence has been found which indicates that any part of the Redwall as here recognized in the Kaibab division of the Grand Canyon is younger than Mississippian.

Ransome, ${ }^{35}$ who has examined the Redwall in the Jerome region, where he collected fossils in it that Girty identified as lower Mississippian, states: "No evidence was obtained at Jerome to indicate that any of the Redwall limestone is as young as the Pennsylvanian." In the Jerome region the beds assigned to the Redwall aggregate only 250 feet and probably belong to the lower part of the formation.

\section{PROBABLE UNCONFORMITY BETWEEN MISSIS-} SIPPIAN AND PENNSYLVANIAN SERIES.

The top of the Redwall limestone is very difficult to reach, except at places near the trails that descend the canyon wall, and I have so far been able to examine it only at the Bass trail, at the trail which ascends the northern wall of the Grand Canyon through Muav Canyon, and at the Hermit, Bright Angel, and Hance (Red Canyon) trails. Viewed from a distance it appears to exhibit no irregularity at most places in the Kaibab division of the canyon.

At Bass Canyon the contact between the typical bluish-gray limestone of the Redwall

${ }^{34}$ Darton, N. H., A reconnaissance of parts of northwestern New Mexico and northern Arizona: U. S. Geol. Survey Bull. 435, p. 21, 1910 35 Ransome, F. L., Some Paleozoic sections in Arizona and their correlation: U. S. Geol. Survey Prof. Paper 98, p. 162, 1916. 
and the red shale at the base of the overlying Supai appears to be remarkably even, and the only evidence of a stratigraphic break is the abrupt change from limestone to shale. However, actual exposures of the contact are not to be found, owing to the softness of the shale, which makes a slope at this horizon that is entirely concealed by talus.

At Muav Canyon the surface of the Redwall is uneven, but the beds are shattered along the axis of a faulted flexure, so that it is uncertain whether the unevenness is due to shattering or to erosion.

At the Hermit, Bright Angel (Cameron), and Hance trails the appearance of the top of the Redwall suggests that it was exposed to erosion before the overlying Supai beds were deposited, as I shall show.

Near the Hermit trail, just south of the point where the trail descends the Redwall, the upper surface of the Redwall limestone is decidedly uneven, and in places jagged knolls of the limestone project 25 feet or more above the general level of the surface. At this locality the basal deposit of the Supai is a bright reddish or purplish sandy shale. Some parts of the shale exhibit no bedded structure whatever; other parts exhibit gnarly, irregular bedding and are more or less concretionary, whereas still other parts are evenly and thinly bedded. Thin lenses of conglomerate occur at some horizons in the shale. The pebbles in the conglomerate are well r. unded and are coated with black "desert varnish." Most of them are composed of chert. derived, apparently, from the underlying limestone. The shale varies considerably in thickness from place to place. Above the tops of the higher limestone knolls the thickness may not exceed 45 feet, but between the knolls, where the deposit appears to fill depressions, the thickness may exceed 70 feet. The deposit becomes more evenly bedded toward the top, and the upper 21 feet consists of thinly laminated soft reddish shale. Above this shale are alternating beds of red sandy shale, purplish and gray limestone containing red chert, and reddish to buff calcareous sandstone. The thickness of these alternating beds is 132 feet. The section just described, 202 feet in total thickness, is shown diagrammatically on Plate XIX. The beds are undoubtedly equivalent to subdivision $\mathrm{C}$ of the Supai at the Bass trail. (See p. 61.)
The upper surface of the Redwall limestone is infiltrated with red mud, and the overlying irregularly bedded, more or less structureless red shale appears to represent just such a deposit of red clay as one would expect to find above a weathered limestone surface. It is possible that the roughness of the top of the Redwall is due to shattering of the beds in this locality, because the formation has slumped in a landslide at the point where the trail descends it. For this reason the evidence just presented should be regarded as inconclusive. Nevertheless the lithologic change from the massive limestone of the Redwall to the structureless red deposit above it is so sharp that it indicates a stratigraphic break at this horizon, and the variation in thickness of the red shale is also suggestive. The bed is 72 feet thick at the Hermit trail, whereas the shale at the corresponding horizon in Bass Canyon is not over 14 feet thick. (See p. 31; also Pl. XIX.)

At the Bright Angel (Cameron) trail the summit of the Redwall is irregular, but here also the evidence is inconclusive, because the Redwall is shattered by a fault in the vicinity of the trail.

At Red Canyon the summit of the Redwall is well exposed near the 4,955-foot bench mark, where the Hance trail descends the Redwall on the east side of the canyon. This locality is some distance east of a fault that coincides with the axis of Red Canyon, so that the beds here have not been disturbed by the fault. Near the bench mark the surface of the Redwall is wavy, and the limestone is more or less infiltrated with red mud, but the best evidence of a stratigraphic break at the top of the limestone is found in the lithologic character of the overlying Supai beds. The Supai begins abruptly with a bed of conglomerate, which exhibits great variations in thickness. At one place it is 20 feet thick, at many places 5 to 10 feet thick, and at some places entirely absent. The conglomerate contains both angular and rounded pebbles of chert and limestone, derived, apparently, from the underlying Redwall. The pebbles range in diameter from a fraction of an inch to 6 inches but average about half an inch. The conglomerate is gravelly and contains very little matrix. Where present the matrix consists of red sandy clay. Where the conglomerate is thickest it appears to fill shallow depressions in the Red- 
wall. Above the conglomerate is 100 feet of red friable sandy shale that is more or less calcareous and in places exhibits concretionary structure, and above the shale are alternating beds of shale, limestone containing red chert, and calcareous sandstone, some of which is cross-bedded. The conglomerate, red shale, and overlying alternating beds just described are undoubtedly equivalent to subdivision $\mathrm{C}$ of the Supai as exposed at the Hermit and Bass trails.

Walcott,$^{36}$ in describing the upper part of the Redwall at Kanab Creek, states:

Toward the close of the 700 feet of limestone and its intercalated cherty bands evidences of an approaching change occur. The horizontal bedding is broken by gradually increasing curves of depression and elevation of the previously level surface. The limestone becomes more and more interstratified with white chert, weathering black. Arenaceous layers of a detrital origin come in, with pink chert and chalcedony replacing the white chert of the beds beneath.

Massive layers of brecciated chert in a quartzitic matrix denote the increasing change of conditions, and soon the sandstone epoch of the Lower Aubrey group opens. The transition beds (a) have filled the hollows and leveled off the uneven surface of the limestone beneath, and, 255 feet above, the great sandstone group begins with a massive cross-bedded sandstone stratum (e), 50 feet in thickness.

The transition beds to which Walcott refers are the beds that constitute subdivision a of his Redwall at Kanab Creek (see Pl. XIX), which is now transferred to the Supai (see p. 62). Therefore the uneven surface which he describes actually lies at the top of the Redwall limestone as here restricted, and the horizon occupied by the uneven surface is equivalent to that at the Hermit, Bright Angel (Cameron), and Hance trails which I have just described.

Schuchert, ${ }^{37}$ who has examined the RedwallSupai contact on the Hermit trail, writes:

The contact may be studied just beneath the signpost "Cathedral Stairs" that stands on Supai strata. It is of the disconformable type, and the Redwall is more or less eroded. Where the contact was studied this limestonedolomite series terminates in thin-bedded deposits, with the beds varying in thickness from 12 to 20 inches. The Supai begins at once with its characteristic sandy and rain-pitted shales and muddy sandstones. This disconformity has far greater significance than the physical phenomena as seen on the Hermit trail would seem to indicate,

36 Walcott, C. D., unpublished notes.

37 Schuchert, Charles, op. cit., p. 358. for the fossils of the Redwall are here all of early Mississippian age. Nothing of later Mississippian time is present, and the land interval preceding Supai deposition was certainly longer than all of Redwall time.

Ransome ${ }^{38}$ reports that 8 miles north of Jerome what he regards as the base of the Supai is a limestone conglomerate 2 to 3 feet thick in which the pebbles are generally less than 2 inches in diameter. He states that layers of a similar conglomerate also occur a little higher in the formation.

In brief, although the evidence just presented is inconclusive, it establishes a strong probability that the upper limit of the Redwall is an unconformity of erosion.

\section{PENNSYLVANIAN AND PERMIAN (?) ROCKS.}

SUPAI FORMATION (REDEFINED).

Definition.-As originally defined by Darton ${ }^{39}$ the name Supai formation was applied to about 800 feet of red sandstones and shales, the latter in part sandy, underlying the Coconino sandstone, overlying the Redwall limestone, and composing the lower part of the Aubrey group in northern Arizona. 'Darton's Redwall limestone, like Gilbert's and Walcott's Redwall, included rocks of Mississippian and Pennsylvanian age. In this report the Supai formation is redefined by cutting off at the top about 300 feet of deep brick-red sandy shale and fine-grained friable sandstone of Permian age, to which the new name Hermit shale is herein applied, and by adding at the bottom about 250 feet of red sandy shale, purplish and gray limestone with red chert, and reddish to buff calcareous sandstone of Pennsylvanian age that have heretofore been included in the Redwall limestone. This redefinition of the Supai formation has been adopted by the United States Geological Survey. As thus defined the Supai formation is of Pennsylvanian and Permian (?) age and rests with probable unconformity on the underlying Mississippian Redwall limestone. The accompanying table shows the different classifications of the Carboniferous rocks of the Grand Canyon.

38 Ransome, F. L., op. cit., p. 162.

${ }^{39}$ Darton, N. H., A reconnaissance of parts of northwestern New Mexico and northern Arizona: U. S. Geol. Survey Bull. 435, pp. 25-27, 1910. 
Classifications of the Carboniferous rocks of the Grand Canyon.

\begin{tabular}{|c|c|c|c|c|c|}
\hline \multicolumn{2}{|c|}{$\begin{array}{l}\text { G. K. Gilbert, 1875. } \\
\text { (U. S. Geog. and Geol. Surveys W. 100th Mer. } \\
\text { Rept., vol. 3, pp. 161-186, fig. 82.) }\end{array}$} & $\begin{array}{l}\text { C. D. Walcott, } 1880 \text {. } \\
\text { (Am. Jour. Sci., } \\
\text { 3d ser., vol. } 20 \text {, } \\
\text { pp. 221-225.) }\end{array}$ & $\begin{array}{l}\text { N. H. Darton, } 1910 . \\
\text { (U.S. Geel.survey } \\
\text { Bull. } 435 .)\end{array}$ & $\begin{array}{l}\text { L. F. Noble, } 1922 \text {. } \\
\text { (This report.) }\end{array}$ & Age. \\
\hline \multirow{3}{*}{ Aubrey group. } & $\begin{array}{l}\text { Cherty limestone, } 200 \text { - } \\
820 \text { feet. }\end{array}$ & Upper Aubrey. & $\begin{array}{l}\text { Kaibab lime- } \\
\text { stone. }\end{array}$ & Kaibab limestone. & \multirow{3}{*}{ Permian. } \\
\hline & $\begin{array}{l}\text { Cross-bedded and other } \\
\text { sandstones, } 300-1,000 \\
\text { feet. }\end{array}$ & \multirow{2}{*}{ Lower Aubrey. } & $\begin{array}{l}\text { Coconino sand- } \\
\text { stone. }\end{array}$ & Coconino sandstone. & \\
\hline & $\begin{array}{l}\text { Red and white shales } \\
\text { and sandstones, } 800 \\
\text { feet. }\end{array}$ & & $\begin{array}{l}\text { Supai forma- } \\
\text { tion. }\end{array}$ & $\begin{array}{l}\text { Hermit shale. } \\
\text {-Unconformity- }\end{array}$ & \\
\hline \multirow{3}{*}{$\begin{array}{l}\text { Redwall lime- } \\
\text { stone group. }\end{array}$} & $\begin{array}{l}\text { Alternating sandstones } \\
\text { and compact lime- } \\
\text { stones, } 200-500 \text { feet. }\end{array}$ & \multirow{3}{*}{$\begin{array}{l}\text { Redwall lime- } \\
\text { stone. }\end{array}$} & \multirow{3}{*}{$\begin{array}{l}\text { Redwall lime- } \\
\text { stone. }\end{array}$} & \multirow{3}{*}{$\begin{array}{l}\text { Supai formation (re- } \\
\text { defined). } \\
\text {-Unconformity (?)- } \\
\text { Redwall limestone } \\
\text { (restricted to Mis- } \\
\text { sissippian lime- } \\
\text { stones). }\end{array}$} & $\begin{array}{l}\text { Permian (?) and } \\
\text { Pennsylva- } \\
\text { nian. }\end{array}$ \\
\hline & $\begin{array}{l}\text { Redwall limestone, } \\
\text { sheer escarpment, } 800 \\
\text { feet. }\end{array}$ & & & & \\
\hline & $\begin{array}{l}\text { Limestones in lesser es- } \\
\text { carpments and cal- } \\
\text { careous shales, } 800- \\
1,365 \text { feet. }\end{array}$ & & & & Mississippian. \\
\hline
\end{tabular}

Character of beds.-The Supai formation as here redefined consists chiefly of sandstone but includes many beds of sandy shale and a few beds of limestone. Much of the sandstone is in thick, massive beds that make strong cliffs. The shales and beds of laminated sandstone make slopes. As seen from a distance, the distinctive features of the formation are its prevailingly red color and its steplike profile, which consists of a succession of cliffs and slopes carved from the alternating hard and soft beds. Close inspection shows that the red color of the formation is derived from the shales. The outcrops of the sandstones are stained reddish by ferritic pigment washed over them from the interbedded shales, but the natural color of the sandstones, as shown on freshly. broken surfaces, is buff or pinkish buff.

The sandstones of the Supai are uniformly fine grained. Some of them are regularly bedded and exhibit thin, platy lamination, but most of them are conspicuously cross-bedded, and in the thicker layers the cross-bedded structure is on a coarse scale. In uniform fineness of grain and in coarseness of cross-bedding the more massive layers resemble the Coconino sandstone. Commonly, however, their grains are bound together by calcareous cement, whereas the binding material in the Coconino is siliceous. Curiously, the prevailing dip of the inclined laminae in the cross-bedded sandstones of the Supai is south, just as it is in the Coconino. Most of the shale in the Supai resembles that of the overlying Hermit shale and is essentially a red sandy mud. Some beds exhibit sun cracks and ripple marks, but these features are not conspicuous at the Bass trail. Two types of limestone occur in the Supai. One type, which is clearly of detrital origin, consists of grains of calcareous sand, exhibits faint cross-bedded structure on weathered surfaces, and in places passes into cross-bedded sandstone. Some beds of this type are crystalline, and others granular; most of them are pinkish buff. The other type of limestone is bluish or purplish gray, massive, and crystalline and contains nodules of red chert. Beds of this type occur only in the lower third of the Supai. Many of them resemble the limestone in the underlying Redwall.

Subdivisions. - At Bass Canyon I have divided the Supai into three members, which in lithol- 
ogy and in topographic expression are sufficiently constant to be recognizable throughout the Kaibab division of the Grand Canyon. These members I have designated subdivisions $\mathrm{A}, \mathrm{B}$, and $\mathrm{C}$.

Near the top and just below the middle of the Supai the cross-bedded sandstones are exceptionally thick and massive and make strong, conspicuous cliffs. Between these two sets of cliffs and below them the strata make steep ledgy slopes. The strata that make the upper set of cliffs constitute subdivision $\mathrm{A}$; those that make the lower set of cliffs and the ledgy slope above the cliffs constitute subdivision B; and those that make the slope at the base of the Supai constitute subdivision C.

Subdivision A consists chiefly of sandstone but includes a few beds of sandy shale; subdivision $\mathrm{B}$ consists chiefly of sandstone but includes beds of sandy shale and a few beds of limestone; and subdivision $\mathrm{C}$ consists of sandstone, shale, and limestone in about equal proportions. Broadly, therefore, although the Supai consists chiefly of sandstone, it exhibits a passage upward from shale and limestone to sandstone.

Subdivisions A and B rest on slightly wavy surfaces at Bass Canyon. However, similar wavy surfaces occur at other horizons in the Supai (see sections of subdivisions B and C, pp.29-31), and some of these surfaces are more irregular than those at the base of subdivisions $\mathrm{A}$ and $\mathrm{B}$. Without further study it is impossible to determine whether any of them have widespread stratigraphic significance.

The order, character, and thickness of the strata that constitute the three subdivisions just outlined are described in the section of the Supai given on pages $29-31$, and the topographic profile of the beds is shown in the columnar section, Plate XIX.

Subdivision C, at the base of the Supai, 208 feet thick, begins at the bottom with alternating beds of red sandy shale and bluish-gray limestone carrying nodules of red chert, and the shales and limestones pass upward into alternating beds of red shale, bluish-gray limestone, and reddish to buff calcareous sandstone, a part of which is cross-bedded. The limestones and harder sandstones form small cliffs, and the shales and softer sandstones form slopes. Outcrops of many softer beds are concealed by talus. The contact between $91048^{\circ}-23-5$ this subdivision and the underlying Redwall limestone is described on pages $57-59$, where I have presented evidence indicating that it is a plane of unconformity by erosion.

Subdivision B, the middle member of the Supai, 439 feet thick, begins at the base with heavy, cliff-making beds of buff cross-bedded sandstone, 200 feet in aggregate thickness, which are separated by thin layers of limestone or red shale. These massive sandstones pass upward into alternating beds of red friable shaly sandstone and cross-bedded calcareous sandstone that contain thin interbedded layers of limestone and, 66 feet below the top of the subdivision, a prominent bed of limestone conglomerate 28 feet thick. This conglomerate (see p. 30), which occurs in highly lenticular layers and consists chiefly of rounded pebbles of limestone embedded in a matrix of red sandy mud, appears to be continuously traceable not only through the Kaibab division of the canyon but far beyond. I have noted it on the Bright Angel (Cameron) and Tanner trails, respectively 18 and 32 miles southeast of Bass Canyon, and in the Aubrey Cliff, near Seligman, 70 miles southwest of Bass Canyon. At all these localities the conglomerate occupies approximately the same horizon in the Supai that it does at Bass Canyon. At the Bass trail and the Bright Angel trail it rests on an uneven surface which exhibits vertical irregularities of several feet within horizontal distances of 100 feet. It is conceivable that the conglomerate marks a stratigraphic break in the Supai that is more significant than the contact between subdivisions $\mathrm{A}$ and $\mathrm{B}$.

Near Pine, in the Jerome region, Ransome ${ }^{40}$ has noted a bed of limestone conglomerate in what he regards as the Supai at a horizon about 450 feet above the base of the formation. The conglomerate is 12 feet thick and overlies a seam of impure lignite.

Subdivision A, at the top of the Supai, 306 feet thick, begins at the base with massive beds of pinkish, purplish, or buff cross-bedded sandstone which form a set of cliffs nearly 200 feet in height. Above these sandstones are alternating beds of soft red platy sandstone and hard buff cross-bedded sandstone which form a series of cliffs and slopes.

At the top of subdivision A is a broad red platform known as the Esplanade, which begins

40 Ransome, F. L., op. cit., p. 160. 
at Bass Canyon and extends far westward in the interior of the Grand Canyon. I have described this platform in a previous report ${ }^{41}$ and have shown that, like every other ledge in the canyon wall, it is a structural bench determined by the hardness of the beds that underlie it and the softness of the beds that overlie it, and that it does not necessarily, as Dutton supposed, ${ }^{42}$ represent a temporary baselevel of erosion produced by a pause in the uplift of the region during the cutting of the Grand Canyon. West of Bass Canyon the Esplanade is so broad that it is by far the most striking feature in the canyon landscape. East of Bass Canyon it shrinks to a narrow ledge and is inconspicuous as a topographic feature but is nevertheless traceable continuously through the Kaibab division. Inasmuch as this bench is cut on the summit beds of the Supai it constitutes a landmark that enables the observer everywhere to distinguish the Supai formation from the overlying Hermit shale. In the region between Bass Canyon and the Hermit trail it marks a conspicuous unconformity between the Supai formation and the Hermit shale. (See pp. 63-64.)

Fossils.-No determinable fossils have been found in the Supai formation in the Kaibab division of the Grand Canyon. The available evidence concerning its age may be summed up as follows:

Subdivision a of Walcott's Redwall at Kanab Creek (see Pl. XIX), "arenaceous beds with pink chert passing down into shaly limestone, brecciated arenaceous cherty beds, and gray limestone with red chert," not only corresponds closely with subdivision C of the Supai as I have defined the formation at Bass Canyon but is overlain at Kanab Creek by massive cross-bedded sandstone (subdivision e of Walcott's "Lower Aubrey group") that corresponds to the massive sandstone at the base of subdivision B of the Supai at Bass Canyon and is underlain at Kanab Creek by massive limestone which is obviously equivalent to the upper part of the Redwall as defined at Bass Canyon. Therefore there can be no reasonable doubt that subdivision a of Walcott's Redwall is subdivision $\mathrm{C}$ of the Supai as here

${ }_{41}$ Noble, L. F., U. S. Geol. Survey Bull. 549, pp. 21, 73-75, 1914.

${ }^{42}$ Dutton, C. E., Tertiary history of the Grand Canyon district: U. S. Geol. Survey Mon. 2, p. 121, 1882. redefined. Subdivision a of Walcott's Redwall is division 5 of Gilbert's Paleozoic section at Kanab Creek, "purple and white arenaceous limestone with pink chert, in one bed passing into cross-bedded sandstone." Walcott ${ }^{43}$ states that although at Kanab Creek he obtained no fossils from these beds nor from any part of the overlying sandstones, "the beds elsewhere have given evidence of their upper Carboniferous age by the presence of a fauna rich in many species." This fauna is the Pennsylvanian fauna described by Meek and listed by Gilbert, ${ }^{44}$ who says concerning it: "The fauna of the upper portion [of the Redwall] is rich in species and, while differing from that of the Aubrey limestone, is equally referable to the Coal Measures." By the "upper portion of the Redwall" Gilbert means not the upper portion of the Redwall as the formation is here restricted, but the beds that constitute division 5 of his section at Kanab Creek ${ }^{45}$ and division 4 of his section at the mouth of the Grand Canyon, ${ }^{45}$. which are equivalent to the lower part of the Supai as here defined. Recently Longwell ${ }^{46}$ has found Pennsylvanian fossils in the Grand Wash Cliffs north of the mouth of the Grand Canyon "near the top of beds which apparently correspond to Noble's basal Supai in the Grand Canyon."

The evidence just presented indicates that subdivision C, at least, of the Supai is of Pennsylvanian age. The Supai is overlain by the Hermit shale, which contains Permian fossils, and the two formations are separated by an unconformity of erosion, but inasmuch as no determinable fossils have been found in subdivisions A and B of the Supai there is no conclusive evidence that the unconformity separates Pennsylvanian and Permian beds. Therefore the Pennsylvanian-Permian contact may lie at any horizon in the Supai between the summit of the formation and the base of subdivision B. However, no stratigraphic break as great as the unconformity at the base of the Hermit shale appears to occur within the Supai itself, so I am inclined to regard the entire Supai as probably of Pennsylvanian age.

43 Walcott, C. D., unpublished notes.

${ }^{44}$ Gilbert, G. K., U. S. Geog. and Geol. Surveys W. 100th Mer. Rept., vol. 3, pt. 1, p. 178, 1875 .

45 Idem, p. 162.

46 Longwell, C. R., Geology of the Muddy Mountains, Nev., with a section to the Grand Wash Cliffs in western Arizona: Am. Jour. Sci., 4th ser., vol. 50, p. 47, 1921. 
Robinson ${ }^{47}$ has reported Pennsylvanian fossils from the Redwall limestone at Elden Mountain, near Flagstaff. He states that at this locality "the limestone becomes thinner bedded than usual and gives way to red calcareous shale and sandstone. The limestone immediately overlying these beds contains many fragments of shale and includes at one point a patch of conglomerate." The fossils determined as Pennsylvanian came "from the uppermost strata" at this locality. In my opinion, Robinson's description of the beds indicates that they are equivalent to strata exposed in the basal part of the Supai in the Grand Canyon, and not to any part of the Redwall limestone as here restricted.

Lee ${ }^{48}$ has also reported a Pennsylvanian fauna from the top of the Redwall limestone in Truxton Canyon, near Yampai. The fossils are stated to have been obtained "near the top of the exposed section." Probably the limestone beds in which Lee found the Pennsylvanian fossils are also correlatives of limestones that lie in the basal part of the Supai at Bass Canyon.

\section{UNCONFORMITY BETWEEN SUPAI AND HERMIT FORMATIONS.}

In Hermit Basin, 12 miles southeast of Bass Canyon, a strong unconformity of erosion separates the Supai formation as here redefined from the overlying red sandy shale here named the Hermit shale. The unconformity is beautifully exposed on the Hermit trail just under a signpost marked "Red Top." (See Pl. XXIII, B.) At this locality the top of subdivision A of the Supai consists of alternating beds of hard pinkish or buff cross-bedded sandstone and friable red platy sandstone. These beds make a succession of small cliffs and ledges just under the bench that forms the floor of Hermit Basin and locally represents the Esplanade platform. Just under the "Red Top" sign a sharp hollow 40 feet deep in these Supai beds is filled with the soft red sandy layers that constitute the Hermit shale. The soft Hermit shale in the hollow determines a break in the small cliffs at the top of the Supai, and the trail takes advantage of this break to descend the

${ }^{47}$ Robinson, H. H., The San Franciscan voleanic field, Ariz.: U. S. Geol. Survey Prof. Paper 76, pp. 21-22, 1913.

${ }^{43}$ Lee, W. T., Geologic reconnaisance of a part of western Arizona: U. S. Geol. Survey Bull. 352, p. 15, 1908. cliffs to a ledge on the summit of the massive sandstone that forms the main cliff of subdivision A. When the observer has examined the unconformity in the fine exposure under Red Top he will have no difficulty in following it with his eye all around the rim of the canyon of Hermit Creek, where it is in plain sight for several miles. The unconformity marks the change from the highest cliff-making strata in the Supai to the softer, shaly beds that overlie them. It is difficult to recognize the unconformity at first sight because the beds above and below it are stained the same color, a deep brick-red. Many fine exposures of the unconformity may, however, be studied by following the trail that leads westward along the general level of the Esplanade from Red Top to Dripping Spring. The sketch in figure $4, a$, and the photograph reproduced in Plate XXIV, $A$, show an exposure of the unconformity on this trail at a point about a quarter of a mile west of Red Top. As seen in the canyon of Hermit Creek the unconformity is comparable in irregularity to the unconformity at the top of the Tonto (see pp. 49-51), which, indeed, it strongly resembles, the eroded surface exhibiting in places irregularities of 50 feet or more.

I discovered the unconformity in 1916 at the end of a field trip when I came out of the canyon over the Hermit trail, and I furnished Prof. Schuchert with a sketch of it which he published in his paper on the Carboniferous formations of the Grand Canyon in 1918. ${ }^{49}$ However, until 1920 I had no opportunity to examine the horizon of the unconformity at other localities, to learn something of its extent, but in the fall of that year I was able to examine it at several points in the south wall of the Grand Canyon northwest and southeast of Hermit Creek. Northwest of Hermit Creek the unconformity is traceable at least 11 miles, being plainly recognizable from the rim of the Grand Canyon in the walls of Ruby Canyon, 2 miles southeast of Bass Canyon. Figure $4, b$, shows it just under Havasupai Point, the end of the promontory that forms the west wall of the Ruby Canyon. The sketch was drawn from the Grand Scenic Divide, a spur of the Esplanade a mile west of Havasupai Point, and may be incorrect in detail, for I could not reach and examine the locality shown by the sketch. At Bass Canyon

${ }^{49}$ Schuchert, Cha les, op. cit., p. 356. 
I could not detect the unconformity, but the beds at its horizon are poorly exposed at that locality.

At the Bright Angel (Cameron) trail, 5 miles southeast of Hermit Creek, the unconformity can be detected by very careful inspection, but the eroded surface exhibits so little relief that it would probably be unrecognizable to one who had not first examined it at the Hermit trail. At Tanner Canyon, 20 miles southeast of the Hermit trail, I could not detect it. In that region the Hermit shale is readily distinguishable from the underlying Supai formation both topographically and lithologically, but the contact with the Supai is so even that if it represents an unconformity of erosion the eroded surface is practically level.
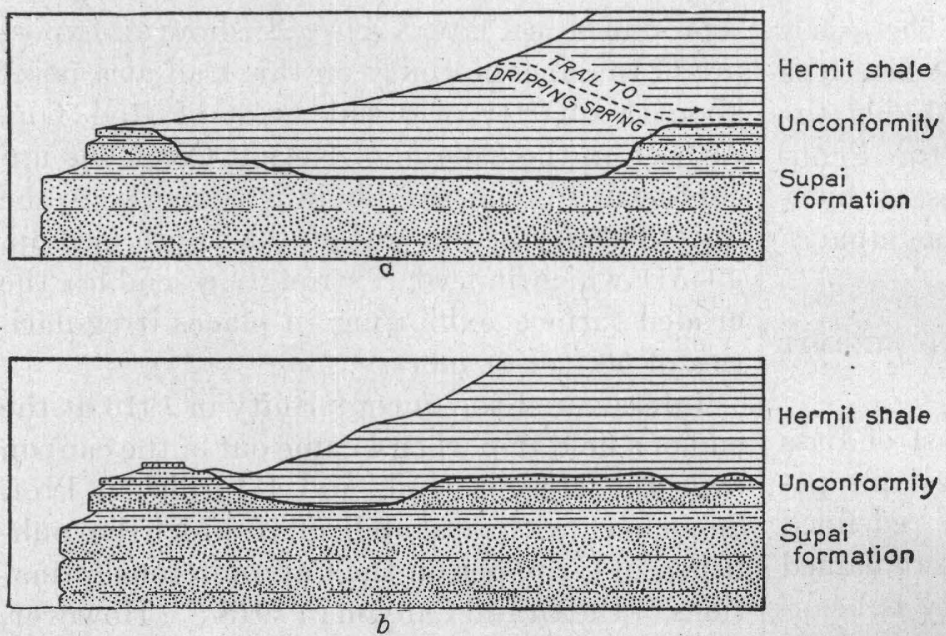

FIGURE 4.-Diagrammatic sketches showing character of unconformity between Hermi shale and Supai formation in Grand Canyon, Ariz. $a$, On trail between Red Top and Dripping Spring, Bright Angel quadrangle; $b$, under Havasupai Point, Shinumoquadrangle.

In brief, although the Supai formation is separated from the overlying Hermit shale by an unconformity of erosion which is continuously traceable for at least 15 miles in the Kaibab division, study of a wider area than I have covered will be necessary before it can be stated confidently that the unconformity is a widespread feature in the Grand Canyon district.

In the area which I have covered the unconformity coincides with the general level of the Esplanade. If this association is significant, the unconformity may extend over a very wide area, for the Esplanade extends many miles west of the Kaibab division in the Grand Canyon.
PERMIAN SERIES.

HERMIT SHALE.

Definition.-At Hermit Basin above the unconformity just described there is a series of deep brick-red sandy shales and fine-grained friable sandstones whose thickness is 317 feet measured from the base of the deepest depression and 267 feet measured from the summit of the highest knoll in the unconformity. (See Pl. XIX.) Formerly these strata were included in the Supai formation and were designated "shale of the Supai formation" or "Upper Supai shale," ${ }^{50}$ but because they have been found to be separated from the underlying beds by an unconformity, because they contain determinable fossils of Permian age, and because they are constant in lithology and are distinct from the underlying beds in topographic expression everywhere in the Kaibab division, I have proposed that they be designated the Hermit shale, and the name has been adopted by the United States Geological Survey. The name is taken from Hermit Basin, where the beds are typically exposed. The formation is conformably overlain by the Coconino sandstone. Plate XXIV, $B$, shows an exposure of the Hermit shale in Tapeats Amphitheater, northwest of Powell Plateau.

Character and thickness.-At Bass Canyon the Hermit shale is 332 feet thick. The character and succession of the beds are given in the section on pages 28-29 and their profile is shown in the columnar section, Plate XIX. The beds differ little from one another in composition and consist essentially of sandy mud colored red by ferritic pigment. The beds that I have designated sandstone in the section are massive and relatively compact as contrasted with the beds that I have designated shale, which are thinly laminated, but the distinction between sandstone and shale is unimportant. All the strata are friable. Many beds exhibit sun cracks and rain prints, and some beds are ripple-marked. One bed (No. 15, p. 29) con${ }_{50}$ Noble, L. F., op. cit., p. 69. 


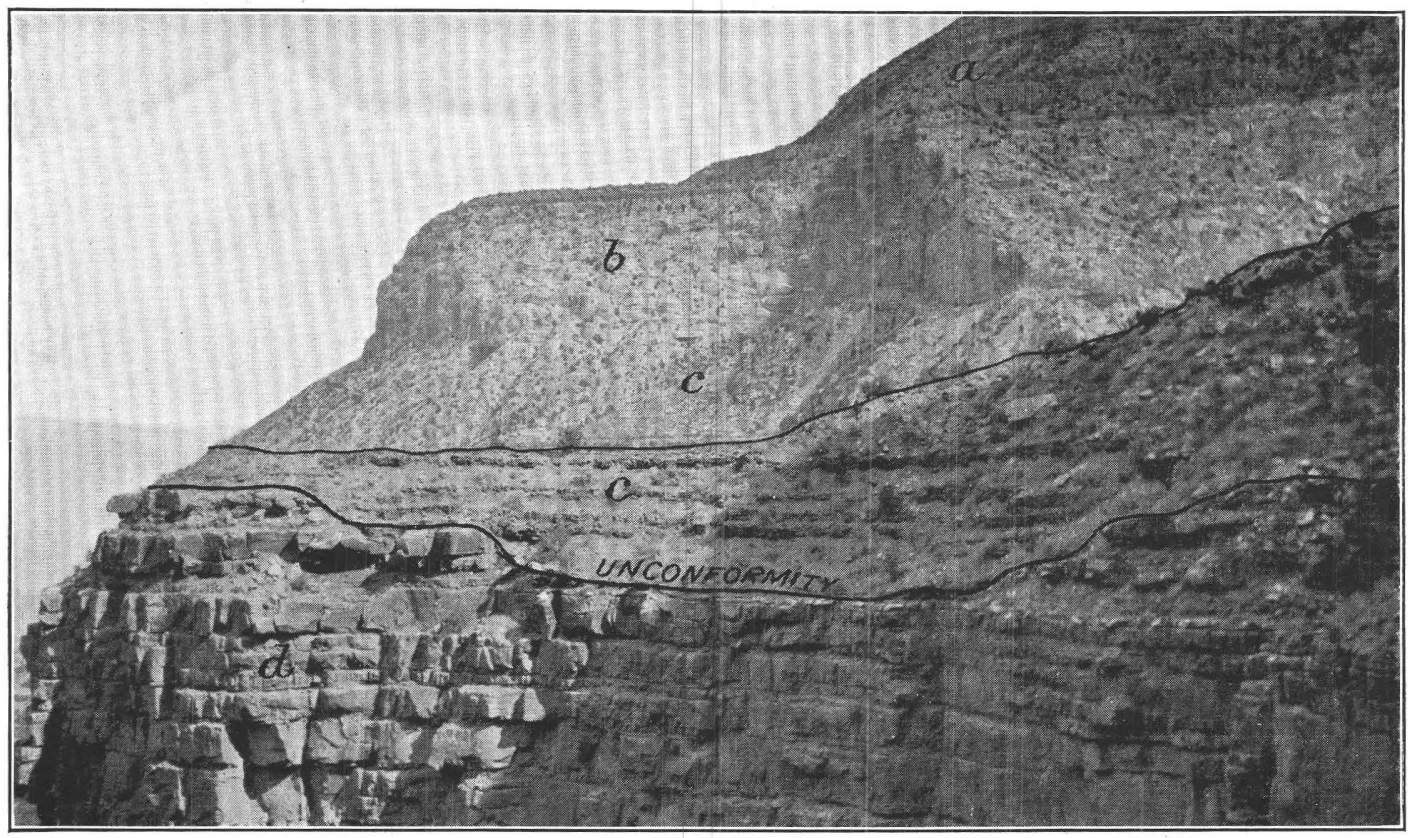

A. UNCONFORMITY BETWEEN HERMIT SHALE AND SUPAI FORMATION ON TRAIL BETWEEN RED TOP AND DRIPPING SPRING, BRIGHT ANGEL QUADRANGLE, ARIZ.

$a$, Kaibab limestone; $b$, Coconino sandstone; $c$, Hermit shale; $d$, Supai formation.

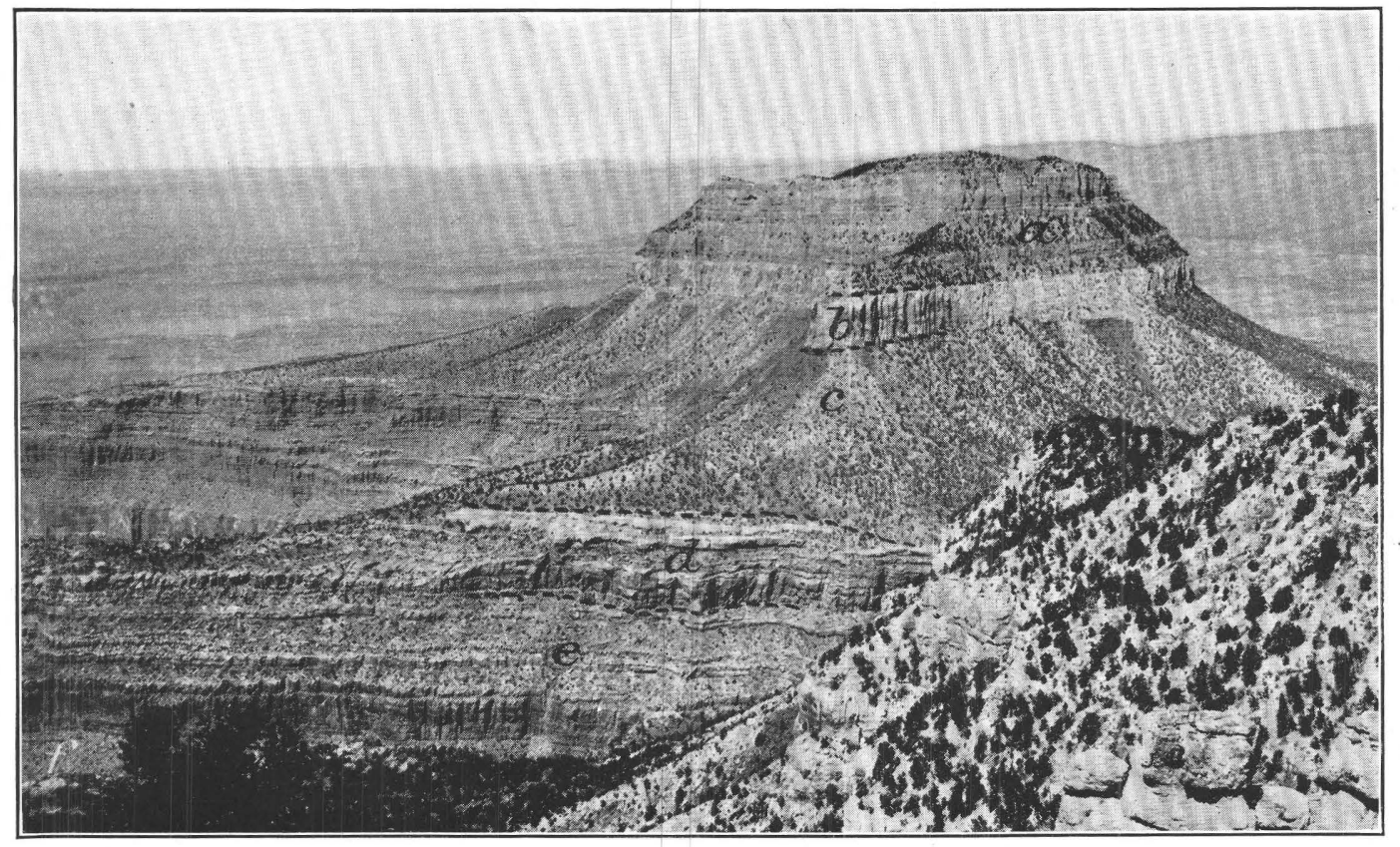

B. TYPICAL EXPOSURE OF HERMIT SHALE IN TAPEATS AMPHITHEATER, NORTHEAST OF POWELL PLATEAU, KAIBAB QUADRANGLE, ARIZ.

$a$, Kaibab limestone; $b$, Coconino sandstone; $c$, Hermit shale; $d, e, f$, subdivisions A, B, C of Supai formation. 


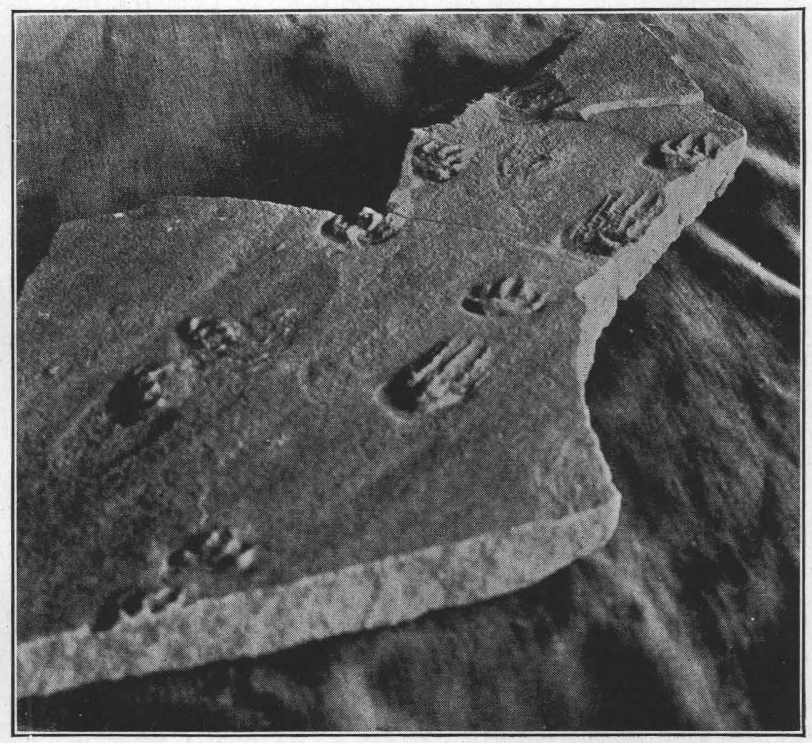

A. FOSSIL TRACKS ON SLAB OF COCONINO SANDSTONE AT HERMIT TRAIL, BRIGHT ANGEL QUADRANGLE, ARIZ.

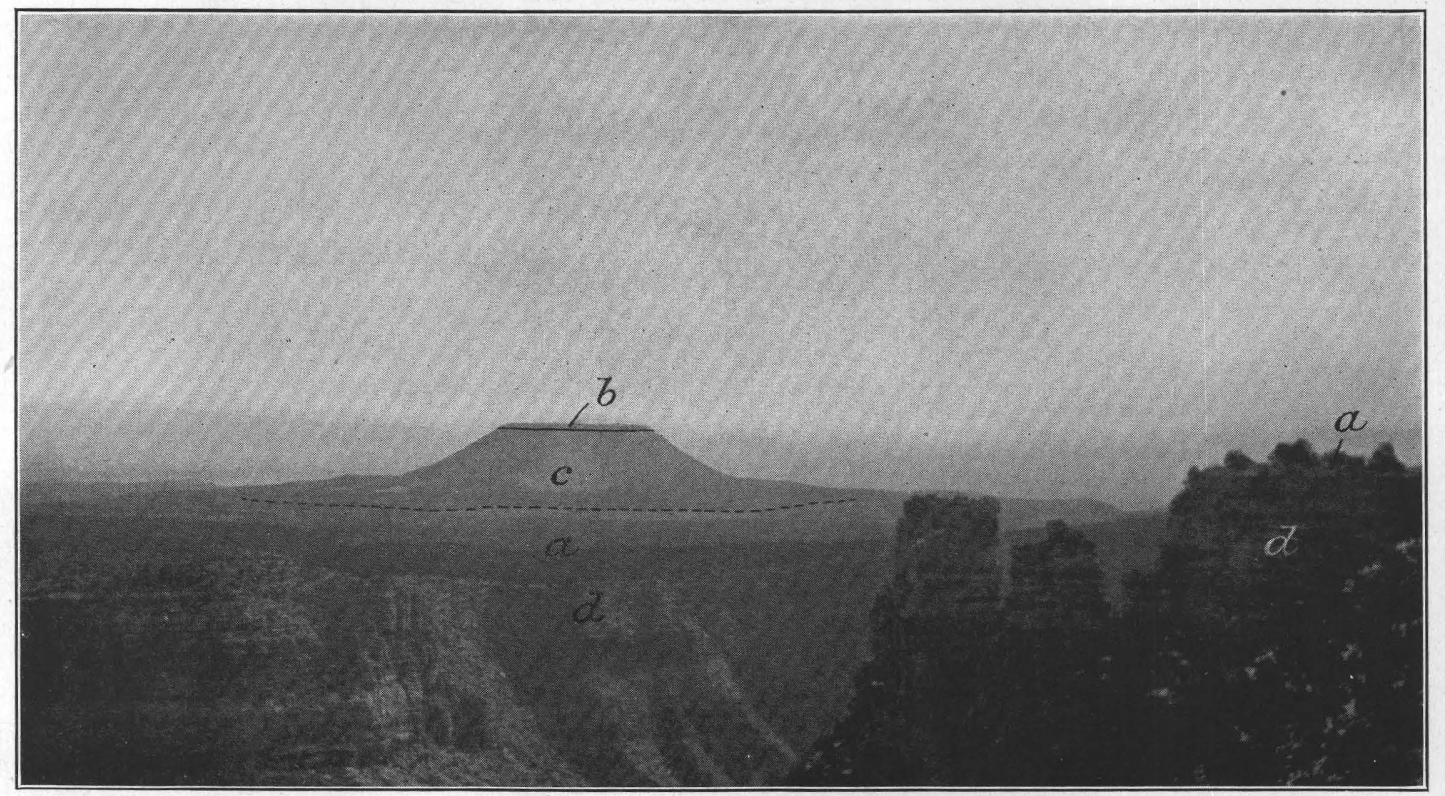

B. Cedar mountain, Vishnu Quadrangle, ARiz., From desert View Camp.

$a$, Surface of Coconino Plateau; $b$, Shinarump conglomerate, capping Cedar Mountain; $c$, Moenkopi formation; $d$, Kaibab limestone. 
sists of intraformational conglomerate. Near the top of the formation many beds exhibit concretionary structure. Lithologically the Hermit shale resembles many beds of sandy shale in the Supai, but unlike the Supai it contains no massive hard layers of crossbedded sandstone, and the more. sandy beds in the Hermit are prevailingly reddish, not buff, as they are in the Supai. Thin, platy lamination is the most prominent structural characteristic of the Hermit shale. Everwhere the formation makes a slope which is in strong topographic contrast with the sheer cliff of the overlying Coconino sandstone and with the steplike cliffs and ledges of the underlying Supai.

Although the Hermit shale is constant in lithology throughout the Kaibab division of the Grand Canyon its thickness varies considerably. In the region about Tanner Canyon, in the eastern part of the Kaibab division, it is less than 100 feet thick (estimated) and may be less than 75 feet. At Bass Canyon it is 332 feet thick, and west of Bass Canyon, at the west end of the Kaibab division, more than 500 feet. The widening of the Esplanade west of Bass Canyon is caused, as I have shown, ${ }^{51}$ by the increase in thickness of the soft Hermit shale, which wastes back from the floor of the platform, in conjunction with a corresponding shrinkage in the overlying hard Coconino sandstone, which defends the retreat of the wall above the platform. Apparently the Hermit shale continues to increase in thickness at least as far as Kanab Creek, for Walcott's subdivisions a1, a2, and a3 of the Aubrey group at Kanab Creek, which I believe represent the Hermit shale, are 775 feet in aggregate thickness. (See Pl. XIX.)

Beds in Gilbert's section at the mouth of the Grand Canyon, ${ }^{52}$ which he designates division 3 and which may represent the Hermit shale, are said to be 800 feet thick at that locality.

In the Aubrey cliff 4 miles north of Seligman beds identical in lithology with the typical Hermit shale underlie the Coconino sandstone and overlie a cliff-making portion of the Supai that corresponds in lithology and in stratigraphic position to subdivision A of the Supai as defined at Bass Canyon. The beds between the Supai and Coconino formations are 80 feet thick, are soft and thinly laminated,

\footnotetext{
${ }^{51}$ Noble, L. F., op. cit., p. 70.
}

52 Gilbert, G. K., op. cit., p. 162. and make a slope above a bench at the top of the Supai that corresponds to the Esplanade. Undoubtedly they are the Hermit shale. In this region the Coconino sandstone, although it is nearly 450 feet thick, does not make a cliff but weathers into a slope that is little steeper than that formed by the Hermit shale. The actual cliff-makers in the Aubrey cliff are the Supai formation and the Kaibab limestone.

Describing the beds in the Jerome region that were believed to represent the Supai, Ransome ${ }^{53}$ writes:

At this locality [mouth of Sycamore Creek, 8 miles north of Jerome] the lower 700 feet of the Supai consists chiefly of fine-grained cross-bedded sandstone in beds less than 6 feet thick, with a smaller proportion of deep-red shale. The general color is not brilliant, and some of the sandstone beds incline to a tawny hue. The upper beds of this division of the formation are fairly massive and form an outer bench in the plateau escarpment at this locality. Overlying them and under the Coconino sandstone are apparently softer beds of much brighter red, with an estimated thickness of 200 to 300 feet. As seen through field glasses at a distance of 2 or 3 miles they show conspicuous cross-bedding and appear to grade upward with no sharp break into the Coconino sandstone.

Perhaps the soft beds noted by Ransome beneath the Coconino sandstone and the rock bench formed by the Supai are the Hermit shale.

Fossits. - Schuchert was the first geologist to find fossils in the Hermit shale. He states : ${ }^{54}$

Just below the sign "Red Top" in the lower turn of the Hermit trail [in Hermit Basin] and immediately above the thick upper sandstone [of the Supai] are seen thin. bedded red shaly sandstones alternating with deep-red zones of shale. The surfaces of the glistening and smooth platy sandstones are replete with fillings of the small prisms of interbedded sun-cracked shales, are often rainpitted, and further marked by the feet impressions of fresh-water amphibians described elsewhere in this number of the Journal by Prof. Lull ${ }^{55}$ as Megapezia? coloradensis and Exocampe? delicatula. Some of the tracks are distinct impressions of the feet, and others are mere strokes of the toes. In these same beds also occur plant remains in very fragmentary condition which were badly macerated and coated with a slime of red mud during their entombment. They are therefore difficult to determine, but after much effort Dr. David White tentatively identified them as Callipteris sp. cf. C. conferta, Walchia cf. W. gracilis, Gigantopteris, and cf. Sphenophyllum. * * *

The plants listed above and found associated with the tracks led White in his letter to the writer dated June 27; 1916, to the following conclusions: "The condition of preservation of the fragments is so bad that caution is

${ }^{53}$ Ransome, F. L., op. cit., p. 162.

54 Schuchert, Charles, op. cit., pp. 353-354.

${ }^{65}$ Lull, R. S., Fossil footprints from the Grand Canyon of the Colorado: Jour. Am. Sci., vol. 45, pp. 337-346, May, 1918. 
necessary in basing conclusions of any kind on the material submitted. However, the presence of Gigantopteris, Walchia, and probably of Callipteris, if my tentative generic identification of the latter is correct, points to lower Permian age of the flora. * * * In any event, it appears probable that the flora, when it is better known, will be found to indicate a level not below the highest stage of the Pennsylvanian."

In 1916 I made a small collection of plant material from beds at the base of the Hermit shale resting in depressions in the unconformity near Red Top in Hermit Basin. The collection was examined by Mr. White, who made the following report:

The fossils are very obscure on account of the maceration of the plant substance, the washing of the surface with mud slimes, with more or less curling, and deformation produced apparently by shrinkage in the sun, so that the nervation is in general obliterated, even the midribs being imperfectly represented in some cases. Curling of the leaves obscures or even conceals their true forms.

One of the specimens probably belongs to the genus Pecopteris. Two other fragments may represent a species of Alethopteris. Another fragment has the outline of Callipteris. If the outline is not misleading as the result of shrinkage and curling of the borders of the leaf, the plant probably is a Callipteris, in which case the evidence of the fossils will conform to the tentative age determinations based upon the collection submitted by Prof. Schuchert, namely, that the beds are Permian in age, or possibly referable to the latest Pennsylvanian.

Pending the collection of additional material, some of which it is hoped will be found better preserved, the reference of the exiremely obscure and imperfect fragments to the Permian must be considered as provisional. I anticipate, however, that more material will point more strongly to the Permian age of the upper part of the Supai formation. Should this prove to be the case, the unconformity at the base of the Permian in northern Arizona will remind geologists of the strong angular conformity beneath the Permian "Red Beds" on the south flank of the Ouachita Mountains in southern Oklahoma and the presence of inconspicuous conglomerate in or near the base of the Permian in northern Oklahoma and southern Kansas.

In $1920 \mathrm{I}$ returned to Hermit Basin and searched the Hermit shale in the hope of getting material that would prove to be specifically determinable, and at a point 50 feet above the base of the formation, a quarter of a mile west of Red Top on the trail to Dripping Spring, at the locality shown in the sketch and photograph (fig. $4, a$, and $\mathrm{Pl}$. XXIV, $A$ ), I obtained among other specimens a well-preserved part of a fernlike frond, concerning which $\mathrm{Mr}$. White writes: ${ }^{56}$

A close inspection shows it to belong to the genus Callipteris, which the world over is everywhere recognized as

56 White, David, personal letter. the most characteristic and widespread exclusively Permian fern. I judge that the specimen is not even varietally distinguishable from Callipteris conferta. Accordingly this evidence practically confirms conclusively the opinions based on fragments previously collected by you and Prof. Schuchert and is of itself probably adequate to prove the Permian age of the Hermit shale. Taken in connection with the plant fragments previously transmitted by Prof. Schuchert and you, it can be only Permian.

In 1920 I noted imperfect fragments of plant impressions here and there in the Hermit shale near the Bass trail and near the Bright Angel trail. The fragments are not confined to any particular bed in the formation but occur at various horizons. They are not nearly so abundant as they are at Hermit Basin.

In the light of the evidence just presented the Hermit shale may be confidently assigned to the Permian.

\section{COCONINO SANDSTONE.}

Character.-The Coconino sandstone is a pale-buff fine-grained cross-bedded sandstone whose distinctive features are its massive appearance, the huge scale of the cross-bedding, and the uniform fineness of the component grains of sand. The massiveness of the sandstone, which is due to the coarseness of the cross-bedding, causes it to weather into the highest and most precipitous cliff in the upper wall of the canyon.

The formation is made up of lenticular beds, each of which is truncated by the bed above it in such a way that, as outlined in cross section or cliff faces, the beds commonly form irregular wedges whose sides are sweeping curves. Each wedge consists of innumerable thin inclined laminae. Horizontal bedding is absent except near the base of the formation, where it is inconspicuous. The wedges differ greatly in thickness. One wedge, near the Bass trail, is more than 75 feet thick; most are between 10 and 75 feet; some are less than 10 feet. In every wedge the laminae dip in a general southerly direction ranging from southeast to southwest, but the dip is not uniform in all parts of the wedge. The laminae form parallel curves that flatten downward. Commonly at the top of a wedge they are inclined at angles of $15^{\circ}$ to $25^{\circ}$, or exceptionally $30^{\circ}$, but near the base of a wedge they bend and become horizontal or nearly horizontal. The prevailing dip of the laminae is south wherever the Coconino sandstone is exposed in northern 
Arizona. This feature causes the formation to make a more continuous cliff in the southern wall of the Grand Canyon than it does in the northern wall, because where the outcropping edges of the sandstone face south, as they do in the northern wall, the sandstone breaks down here and there into slopes on the dip of the laminae. A break of this character permits the Hermit trail to descend the sandstone in Hermit Basin, and another permits the Bass trail to descend it near Bass Camp. At both places the Coconino cliff faces southwest in an alcove cut at right angles to the prevailing dip of the beds.

The sandstone is cut by many vertical joints. In weathering, it splits into blocks along these joints or into slabs along the inclined laminae rather than along contacts between the wedges. Although the prevailing color of the sandstone is pale buff, some wedges are rusty buff, pinkish, or pale red. The reddish color, where present, is strongest, as a rule, at the base of a wedge. The constituent grains of the Coconino sandstone are quartz, and they are bound together by siliceous cement; the rock does not effervesce with acid. Commonly the grains are uniformly small, translucent to transparent, and rudely globular or subangular rather than broken or angular, but fresh surfaces of the rock feel gritty and sparkle in the sunlight. Exceptionally the grains are rather coarse, are well rounded, and are dull on the surface, like ground glass. These dull, rounded grains commonly form thin bands or streaks.

Ripple-marked or sun-cracked surfaces are very rarely seen in the Coconino sandstone. I have never seen ripple marks in it, but Sehuchert $^{57}$ has noted them at one place, near the Hermit trail. Near the Bass trail the under surface of the formation contains distinct impressions of sun cracks, but these impressions are derived from the upper surface of the underlying Hermit shale. The only sun cracks I have noted that are unmistakably within the Coconino itself are on a block in a talus slide near the Hermit trail.

At the Bass, Hermit, and Tanner trails the sandstone at the base of the Coconino is in horizontal layers for 5 to 25 feet above the Coconino-Hermit contact, and some of these layers do not exhibit cross-bedding. At the Tanner trail these horizontal beds of sandstone

${ }^{57}$ Schuchert, Charles, op. cit.s p. 349. alternate with layers of red shale, so that the boundary between the Hermit shale and Coconino sandstone is not sharp. At the Bright Angel (Cameron) trail the cross-bedding begins abruptly at the base of the Coconino.

At the Hermit and Bright Angel trails the beds at the top of the Hermit shale are cut here and there by vertical fissures that do not extend upward into the Coconino sandstone. These fissures, some of which extend downward 15 to 20 feet into the Hermit shale and are 6 inches to a foot wide at the top, are filled with the buff sand that constitutes the overlying Coconino sandstone. Probably they are a widespread feature of the Coconino-Hermit contact, for a few of them are exposed under Fossil Mountain, near Havasupai Point, 11 miles from the Hermit trail. I have not seen them at Red Canyon or at Tanner Canyon, but the contact is poorly exposed at those localities.

The Coconino-Hermit contact is the most favorable horizon for springs in the upper part of the canyon wall, because the upper surface of the relatively impervious Hermit shale checks the downward movement of ground water percolating through the more pervious Coconino sandstone. Many small springs issue at this contact in the Kaibab division of the canyon. Dripping Spring, at Hermit Basin, and a spring at the Muav Saddle, near the head of Muav Canyon, are examples.

Thickness.-In the region between Kanab Creek and the east end of the Kaibab division the thickness of the Coconino sandstone increases steadily southeastward and is everywhere in inverse ratio to that of the underlying Hermit shale. For example, the Coconino is only 30 feet thick at Kanab Creek (see section by Walcott, Pl. XIX), where beds believed to represent the Hermit shale are 775 feet thick; 250 feet thick at the west end of the Kaibab division, where the Hermit shale is 550 feet; 330 feet at the Bass trail, where the Hermit shale is 332 feet; 350 feet at the Hermit trail, where the Hermit shale is 267 to 317 feet; 550 feet (estimated) at Red Canyon, where the Hermit shale is 130 feet (estimated); and 550 to 650 feet in the eastern end of the Kaibab division, between the Tanner trail and the Little Colorado, where the Hermit shale is 75 to 100 feet. The height of the Coconino cliff as seen from Desert View near the Tanner trail is 
thus almost double the height of the cliff as seen from the head of the Hermit trail or from Bass Camp.

Fossits.-The only traces of life that have been found in the Coconino sandstone are fossil footprints of small animals. The locality is on the Hermit trail between 140 and 200 feet above the base of the sandstone and is easily accessible. The tracks occur on the upper surfaces of inclined laminae of the sandstone that $\operatorname{dip} 15^{\circ}-25^{\circ} \mathrm{SW}$., and they are found over a considerable area between the elevations stated. The beds that contain the tracks have a slightly darker color than most of the Coconino sandstone exposed on the trail, weathering a rusty buff. The tracks are hard to recognize at first, as they are small, like those of a squirrel or a small cat, and the impressions are faint, but the tracks are abundant, and the observer will see a great many of them after he has become familiar with their appearance. Most of them appear to have been made by animals walking up the slope of the inclined laminae. A large number will be found in place on the outcropping inclined surfaces of the sandstone, but many loose slabs of rock scattered about the trail contain good impressions. The photograph reproduced in Plate XXV, $A$, shows impressions on one of these slabs. Specimens of two kinds of tracks collected by Prof. Schuchert in 1915 and by me in 1916 have been described by Lull ${ }^{58}$ as Laoporus schucherti and Laoporus noblei. He regards the animals that made them as ancestral amphibia. He states:

The creatures which made the footprints were quadrupeds of moderate size, with broad, stumpy feet, apparently clawed, and having at least four toes in front and five behind. The hind foot, which is somewhat the larger, bore a proportionately greater share of the creature's weight, especially in the smaller species. The limbs were apparently short, with a wide trackway, implying a bulky body. No trace of a dragging trail is discernible on any of the specimens, and the body was evidently carried clear of the ground. Several known genera of Paleozoic footprints may be compared with the present species, but none agrees with sufficient closeness to warrant the inclusion of these forms. They therefore seem to pertain to a new genus, which will be called Laoporus and the affinities of which, from the criteria which they present, seem to lie with the genus Limnopus Marsh, from the Kansas Coal Measures.

Probably the specimens described do not represent all kinds of tracks obtainable at this locality, for in examining the locality more

${ }_{58}$ Lull, R. . S., op. cit., pp. 338-341. carefully in $1920 \mathrm{I}$ noted tracks that differ from those already described.

In origin I believe the Coconino sandstone is essentially a dune deposit, because it resembles in many structural and lithologic features parts of younger formations exposed in the Navajo country, notably the DeChelly, Navajo, and Wingate sandstones, which, as Gregory ${ }^{59}$ has shown, are almost certainly dune deposits. Thin sections cut from specimens of the Coconino sandstone that I have collected for study may throw more light on the origin of the sand. This material, however, which also includes thin sections cut from beds in other Paleozoic formations of the Grand Canyon, has not yet been studied, and I will reserve a discussion of it for another report.

\section{KAIBAB LIMESTONE.}

Character.-The Kaibab limestone forms the surfase of Coconino and Kaibab plateaus, which border the Grand Canyon, and makes the first cliffs that drop away at the rim of the canyon. It is composed of limestone and sandstone and at some horizons contains large amounts of chert. Fragments of chert weathered from the formation are abundant nearly everywhere on the surface of the plateaus. The beds of limestone are hard and make cliffs in the canyon wall; the sandstones are soft and make slopes. Relatively the Kaibab is not a heavily bedded formation, like the Redwall. Some limestone beds are over 6 feet thick, but many are from a few inches to 5 feet thick. The bedding planes are distinct throughout the formation. The prevailing colors of the limestones and of most of the sandstones are buff, cream, or gray, but some of the sandstones, notably in the middle part of the formation, are red or yellow. The limestones in the upper part of the formation are the most fossiliferous rocks in the Grand Canyon, some beds being composed almost entirely of the remains of sea animals, chiefly bryozoans, sponges, brachiopods, and gastropods. Fossil Mountain, a dissected promontory of the Coconino Plateau near Bass Camp, is carved from these fossiliferous beds and is so named because the fossils, weathered from the limestone, litter its southwest slope.

At Bass Canyon the Kaibab limestone is divisible into three members which in lithology and in topographic expression are distinct from

${ }_{59}$ Gregory, H. E., Geology of the Navajo country: U. S. Geol. Survey Prof. Paper 93, pp. 31-34, 53-55, 57-59, 1917. 
one another everywhere in the Kaibab division. Subdivision A, at the top of the formation, 292 feet thick, consists of gray crystalline limestone which passes at the base and top into alternating beds of fine-grained sandstone and very cherty limestone. Subdivision B, in the middle of the formation, 136 feet thick, consists of more or less irregularly bedded buff, yellow, and red fine-grained sandstone and contains beds of sandy breccia. Subdivision C, at the base of the formation, 134 feet thick, consists of alternating beds of buff sandstone and limestone which pass up into a very massive bed of siliceous limestone. Subdivision A forms cliffs and steep slopes, B forms a slope, and C forms a succession of cliffs and slopes. The order, character, and succession of the beds that constitute these subdivisions are described in the section on pages $27-28$, and the profile of the subdivisions is shown in the columnar section, Plate XIX.

Two analyses of limestone in subdivision A follow. One analysis shows the composition of a sample taken from a bed (No. 2, p. 27) just under the rim of the canyon at the Bass trail. This limestone is associated with the sandy beds in the upper part of the subdivision. It is dense but not crystalline, feels dull or earthy when struck by the hammer, and in appearance suggests silicified chalk. Similar beds higher in the Kaibab limestone are exposed on the Coconino Plateau east of Bass Camp but are not included in my section.

This rock is an impure dolomite. The second analysis shows the composition of the limestone that forms the greater part of the subdivision. This limestone is hard, gray, more or less cherty, very fossiliferous, and entirely crystalline. The sample analyzed was taken from bed No. 6 at the Bass trail. (See p. 27.) The analysis shows that this limestone is not magnesian, although it is relatively impure. Probably the insoluble impurities are largely the silica that forms nodules of chert associated with the limestone, for the rock represented by the sample analyzed contains no detrital sand.

Partial chemical analyses of limestone from subdivision $A$, Kaibab limestone.

[Alfred A. Chambers, analyst.]

\begin{tabular}{|c|c|c|}
\hline & 1 & 2 \\
\hline 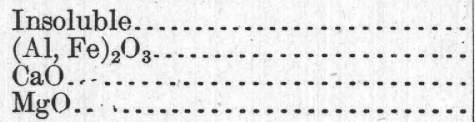 & $\begin{array}{r}6.98 \\
.56 \\
29.98 \\
18.68\end{array}$ & $\begin{array}{r}11.15 \\
.71 \\
48.68 \\
.00\end{array}$ \\
\hline
\end{tabular}

The sandstones of subdivision B consist entirely of quartzose sand which in composition, fineness, and uniformity of grain resembles the sand in the Coconino sandstone. Much of the sandstone is loosely consolidated and crumbles to sand when struck with the hammer. The cement appears to be siliceous, for the rock does not effervesce with acid. Some beds are evenly laminated; others exhibit curious gnarly structure like that in parts of the Devonian Temple Butte limestone (p. 51). Wavy, irregular surfaces separate many beds. A bed of brecciated sandstone occurs at the top of the subdivision at Bass Canyon, and a similar bed occurs near the middle. (See p. 27.) It is difficult to determine from the exposures at this locality whether the brecciated structure is detrital in origin, the fragments representing boulders in a conglomerate, or whether the structure was acquired after the beds were consolidated, the beds caving in and breaking because some soluble mineral, perhaps gypsum, was leached out of them. The sandstones of the subdivision contain no gypsum at the Bass trail, but equivalent beds at Kanab Creek described by Walcott (see Pl. XIX) contain gypsum, as also do equivalent beds at Cataract Creek described by Newberry. ${ }^{60}$ Cataract Creek is about 20 miles southwest of Bass Canyon.

The prevailing reddish and yellowish hues of the sandstones that constitute subdivision B contrast strikingly with the pale buffs and grays of the strata in the overlying and underlying subdivisions of the Kaibab and enable the observer readily to distinguish the subdivision.

In general appearance the limestone in the massive cliff-making bed at the top of subdivision C (see p. 28) resembles that in the bed at the top of subdivision A, whose composition is shown by the analysis on this page to be near that of dolomite. Probably the rock is a siliceous dolomitic limestone. The sandstones that alternate with the limestones below this bed do not appear to differ conspicuously in composition from those in subdivision B, but all of them are evenly bedded, and some exhibit shaly lamination. The contact between subdivision $\mathrm{C}$ and the underlying Coconino sandstone is level and even, and the bottom bed of the subdivision,

${ }_{60}$ Newberry, J. S., Report upon the Colorado River of the West, explored in $1857-58$ by Lieut. J. C. Ives, pt. 3, Geological report, 1861. 
a fine-grained reddish to yellowish sandstone, rests everywhere on the truncated edges of inclined laminae of the Coconino sandstone.

Thickness.-The Kaibab limestone is 562 feet thick at the Bass trail and about 25 feet thicker a short distance east of the trail, but inasmuch as the summit of the formation is the eroded surface of the Coconino Plateau, the original thickness can not be determined. In fact, the only place where it can be determined in the Kaibab division is in the area between the rim of the Grand Canyon and Cedar Mountain, 35 miles southeast of Bass Canyon. At Cedar Mountain, 2 miles from the rim of the canyon, the Kaibab is overlain by younger beds that have not been removed by erosion, and the top of the Kaibab is exposed beneath these beds at the southern base of the mountain. As shown on page 72 certain beds at the top of the Kaibab at the base of the mountain can be identified with beds exposed at the top of the Kaibab at the rim of the canyon 2 miles away. Therefore the original thickness of the Kaibab can be obtained by measuring the formation in the canyon wall at this point and adding the thickness of Kaibab beds exposed under Cedar Mountain that have been removed at the rim of the canyon. These measurements have not been made.

Although the three subdivisions of the Kaibab limestone are everywhere readily distinguishable from one another they exhibit variations in thickness and lithology as they are traced southeastward through the Kaibab division from Bass Canyon. At Red Canyon, on the Hance trail, 30 miles southeast of Bass Canyon, subdivision $\mathrm{C}$, at the base of the formation, is 75 feet thick, whereas at Bass Canyon it is 134 feet thick. The cliff-making bed of buff limestone at the top of the subdivision is about equally thick at both localities, but the alternating sandstones and limestones between this bed and the Coconino sandstone have shrunk from 86 feet at Bass Canyon to 30 feet at Red Canyon.

Subdivision B is 143 feet thick at Red Canyon, practically of the same thickness as at Bass Canyon, and the component beds of sandstone differ very little at the two localities. The subdivision contains brecciated sandstone at Red Canyon, as it does at Bass Canyon, but at Red Canyon the brecciated sandstone occupies a horizon near the middle of the subdivision, whereas at Bass Canyon it occurs at both the middle and the top. At Red Canyon the brecciated sandstone forms a bed 15 feet thick and consists of angular fragments of red and buff sandstone as much as 4 feet in diameter embedded in a matrix of gnarled and twisted sandstone. At this locality the brecciated sandstone appears to represent a conglomerate, not a bed shattered after deposition and consolidation. Undoubtedly these brecciated beds are a constant feature of subdivision B, for I have seen them at all localities where I have examined the subdivision between Bass Canyon and Red Canyon. One of these beds is exposed on the Hermit trail.

Subdivision A is 355 feet thick at Red Canyon and 292 feet thick at Bass Canyon, but the summit is eroded at both places, so that the differences in thickness may not be significant. At Red Canyon, as at Bass Canyon, chert is less abundant in the middle of the subdivision than near the base and top and is most abundant near the top. The limestone in the subdivision at Red Canyon, however, is not nearly so pure as it is at Bass Canyon, is not prevailingly crystalline, and most beds are earthy, sandy, or siliceous, resembling the buff magnesian limestone at the top of the Bass Canyon section rather than the gray crystalline limestone that constitutes the greater part of the subdivision at Bass Canyon. Thus subdivision $\mathrm{A}$ as a whole becomes sandier and more siliceous southeastward from Bass Canyon. The limestones are decidedly more sandy at the Hermit trail than they are at the Bass trail and more sandy at Red Canyon than they are at the Hermit trail.

Fossils.-Fossils are very abundant at many horizons in subdivision A. At Bass Canyon they are most abundant in the beds of gray crystalline limestone designated 5 and 6 in my section (p. 27). The following list of a collection in the possession of G. H. Girty obtained at Parusi-Wompats Spring, just north of the Shinumo region, includes most of the forms that occur near Bass Canyon: ${ }^{61}$

Sponges.

Lophophyllum n. sp.

Crinoid stems.

Fistulipora sp.

${ }^{16}$ Noble, L. F., op. cit., p. 71. 
Meekopora sp.

Stenopora sp.

Septopora sp.

Polypora sp.

Lingulidiscina convexa?

Derbya sp.

Meekella pyramidalis.

Chonetes aff. C. hillianus.

Producus occidentalis.

Productus ivesii.

Productus aff. P. irginae.

Productus subhorridus var. rugatulus.

Productus sp.

Pugnax osagensis var.

Heterelasma n. sp.

Squamularia guadalupenঞis?

Spiriferina campestris?

Composita subtilita.

Aviculipecten, $2 \mathrm{sp}$.

Acanthopecten occidentalis.

Pseudomonotis aff. P. hawni.

Pseudomonotis? sp.

Anisopyge perannulata?

These and other fossils constitute the socalled Productus ivesii fauna. Girty regards this fauna as Permian and tentatively correlates the Kaibab limestone with the San Andres limestone in the Manzano group of New Mexico.

No fossils have been found in subdivision $\mathrm{B}$, the sandstone member of the Kaibab, but a few occur in subdivision C. So far as I know, no fossils have been collected and described from these two lower subdivisions of the Kaibab limestone in the Grand Canyon, and it is therefore conceivable that the lower part of the formation may contain a fauna differing somewhat from that in the upper part. However, Newberry's section at Cataract Creek ${ }^{62}$ mentions Productus ivesii in beds equivalent to those at the base of subdivision C. Inasmuch as the Hermit shale beneath the Kaibab contains Permian plant remains, no part of the Kaibab can be older than Permian.

\section{BEDS OVERLYING THE KAIBAB LIMESTONE AT CEDAR MOUNTAIN.}

No beds younger than the Kaibab limestone are exposed in the wall of the Grand Canyon in the Kaibab division, but Cedar Mountain, a flat-topped butte on the Coconino Plateau only 2 miles east of the rim of the canyon near Desert View Camp, is carved from younger beds. These beds at Cedar Mountain constitute two formations-the Shinarump conglom-

${ }^{62}$ Newberry, J. S., op. cit. erate, 25 feet thick, which makes a cliff encircling the top of the mountain and determines its flat summit, and the Moenkopi formation, 481 feet thick, which makes the slopes of the mountain. The age of these two formations is Mesozoic, the Moenkopi being regarded as Lower Triassic and the Shinarump as probably Upper Triassic. The Moenkopi formation, which is relatively soft, owes its preservation to the hard Shinarump conglomerate that caps it. Cedar Mountain is accessible by a rather poor road or may be reached by walking 3 or 4 miles across country from Desert View Camp, which is connected with El Tovar by a good road. It is interesting not only because it affords evidence that the Moenkopi and Shinarump formations once covered the Grand Canyon region, but because the Shinarump conglomerate, which caps it, contains petrified wood. Plate $\mathrm{XXV}, B$, shows Cedar Mountain as seen from Desert View Camp.

Inasmuch as the formations in Cedar Mountain are exposed within 2 miles of the rim of the Grand Canyon they may be considered a part of the Grand Canyon stratigraphic section, and I have therefore included a section of them in the present report. This section, which follows, is probably inaccurate in detail, because I obtained the thicknesses of the beds by rough aneroid measurement and because the exposures of many beds are poor owing to the apron of débris that cloaks the slopes of the mountain. However, the section serves to give a general idea of the character and succession of the beds.

Section of beds exposed on south side of Cedar Mountain, Vishnu quadrangle.

Shinarump conglomerate (Upper? Triassic): Hard siliceous conglomerate or pebbly grit composed chiefly of pebbles of quartz or jasper embedded in a matrix of quartzose sand; caps Cedar Mountain and forms strong cliff. Cross-bedded throughout; texture variable, some beds fine grained, others coarse grained. Rounded pebbles of white quartz a quarter of an inch to an inch in diameter predominate in the coarser beds; the jasper pebbles are of different colors and are banded and variegated; probably the jasper is petrified wood. Several logs of petrified wood are embedded in the conglomerate. The constituent pebbles of the conglomerate are unidentifiable with any rock in the underlying Moenkopi............ 
Unconformity (?). The contact between the Shinarump conglomerate and the underlying shale is concealed nearly everywhere by talus. The only exposure noted, a few feet in horizontal extent, shows conglomerate resting on reddish-brown sandy shale; lithologic change from shale to conglomerate very sharp.

Moenkopi formation (Lower Triassic):

1. Slope; practically all covered by débris. The few outcrops, consist of thinly laminated reddish-brown shale or shaly sandstone.

2. Strong cliff; very massive reddish-brown fine-grained, strongly cross-bedded sandstone............................

3. Slope; soft, thinly laminated tan to reddishbrown sandy shale. Outcrops covered with white saline efflorescence, indicating the presence of much saline material in the rock.........................

4. Weak cliff; rather massive buff sandstone exhibiting indistinct cross-bedding....

5. Slope; thinly laminated tan sandstone or sandy shale.

6. Cliff; light yellowish-buff to creamy-buff fine-grained rather massive cross-bedded sandstone.

7. Long, gentle slope almost entirely covered by talus. The few outcrops are mostly thinly laminated soft brownish or reddish shale. The upper part of this member, just under the overlying buff sandstone, is bright-vermilion shale; the basal portion is slabby fine-grained thin-bedded sandstone which exhibits lemon and tan tints and is markedly calcareous........

8. Tiny cliff; greenish-buff, thinly laminated crystalline limestone, somewhat sandy in places. . . . . . . . . . . . . . . . . . . .

9. Slope; platy, very thinly laminated greenish and brownish-buff calcareous shaly sandstone, passing up into brownish-buff and vermilion beds of the same character

10. Curious gnarly cherty bed. In places a conglomerate of angular chert fragments; in places a massive gnarly sandy chert. Thickness variable. .................

11. Massive yellowish-buff fine-grained sandstone. Thickness variable............

Unconformity (?). Theirregularity of the beds at this horizon and the presence in them of brecciated chert indicate a surface of erosion, but the outcrops are not of sufficient extent to afford conclusive evidence.

Feet.

Kaibab limestone (Permian):

1. Massive buff sandstone containing lenses of chert and many casts of fossils; casts of Productus? are the most abundant. Thickness of bed variable and its surface appears wavy ......................

2. Partly concealed bed, making slope. Apparently consists of alternating thin layers of chert and lemon-buff sandstone..............................

3. Cliff; massive gray to buff sandstone; calcareous; contains casts of Productus? ....

60

80

130

16

5

18

1

15

$0-4$ $-2$

(n)

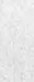

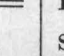

\section{S} Moenkopi and Kaibab can not be determined.
by conclusive evidence at Cedar Mountain,

${ }^{63}$ Gregory, H. E., op. cit., p. 24. 
because the exposures of the contacts between Longwell ${ }^{64}$ in Nevada and determined by the formations are of small extent, but inas- Girty show that its age is Lower Triassic. much as Gregory has shown conclusively that Therefore the probable unconformity between these unconformities exist in the general the Moenkopi formation and the Kaibab region and are widespread, it is highly probable limestone separates deposits of the Paleozoic that the features I have described as occuring at the contacts between the formations at Cedar Mountain indicate their presence.

I obtained no fossils in the Moenkopi at and Mesozoic eras.

Gregory ${ }^{65}$ has tentatively assigned the Shinarump conglomerate to the Upper Triassic.

Cedar Mountain, but fossils collected in it by

${ }_{64}^{64}$ Longwell, C. R., op. cit., p. 50.

65 Gregory, H. E., op. cit., p. 41. 